\author{
UNIVERSIDADE DE SÃO PAULO \\ Faculdade de Filosofia, Letras e Ciências Humanas \\ Departamento de Linguística \\ Programa de Pós-Graduação em Semiótica e Linguística Geral
}

\title{
Aspecto Verbal na Língua Dâw
}




\section{UNIVERSIDADE DE SÃO PAULO \\ Faculdade de Filosofia, Letras e Ciências Humanas \\ Departamento de Linguística \\ Programa de Pós-Graduação em Semiótica e Linguística Geral}

Maurício Oliveira Pires de Carvalho

Dissertação de mestrado apresentada ao programa de

Pós-Graduação em Semiótica e Linguística Geral da Faculdade de Filosofia, Letras e Ciências Humanas da Universidade de São Paulo como requisito para obtenção do título de mestre em Letras

\section{Orientadora: Prof ${ }^{\mathrm{a}} \mathrm{Dr}^{\mathrm{a}}$ Luciana Raccanello Storto}

São Paulo 
Folha de Aprovação

Autor: Carvalho, M O P (Maurício Oliveira Pires de Carvalho)

Título: Aspecto Verbal na Língua Dâw

Dissertação de mestrado apresentada ao programa de Pós-Graduação em Semiótica e Linguística Geral da Faculdade de Filosofia, Letras e Ciências Humanas da Universidade de São Paulo como requisito para obtenção do título de mestre sob orientação da Prof ${ }^{a}$ Dr $^{a}$ Luciana Raccanello Storto.

BANCA EXAMINADORA

Dra. Luciana Raccannello Storto (presidente - USP)

Dr. Paulo Chagas de Souza - Titular (USP)

Dr. Marcos Fernando Lopes - Suplente (USP)

Dra. Ana Lúcia de Paula Müller - Suplente (USP)

Dra. Maria Filomena Spatti Sandalo (UNICAMP)

Dra. Bruna Franchetto (UFRJ) 
Esta pesquisa foi apoiada por uma bolsa Capes, no Programa de Pós-Graduação em Linguística do Departamento de Linguística da Universidade de São Paulo.

Os trabalhos de campo em que se baseia realizados foram financiados por:

- Projeto ELDP do SOAS da University of London intitulado "Documentation of Dâw, a Nadahup language of Brazil”, que teve vigência de março 2013 a fevereiro 2014. Proponentes: Patience Epps (University of Texas) e Luciana Storto (USP).

- Programa de Pós-Graduação em Semiótica e Linguística Geral do Departamento de Linguística da USP - CAPES/PROEX. Julho de 2015.

O trabalho de documentação sobre este tema será continuado financiado por:

- Projeto Regular da Fundação de Amparo à pesquisa do Estado de São Paulo (FAPESP) e da Universidade do Texas intitulado" Language Contact and Change in the Upper Rio Negro", que teve vigência de outubro de 2015 a setembro de 2017. Proponentes: Luciana Storto (USP) e Patience Epps (University of Texas). 
À minha filha Sofia 


\section{Sumário}

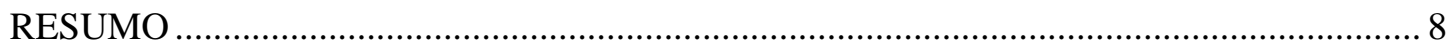

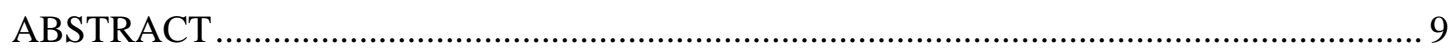

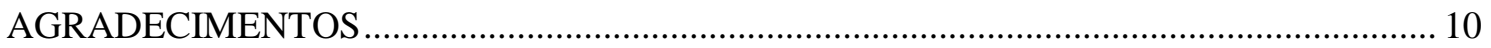

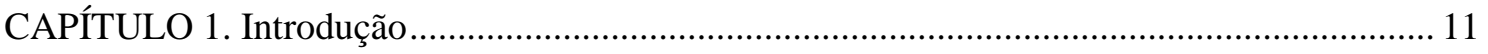

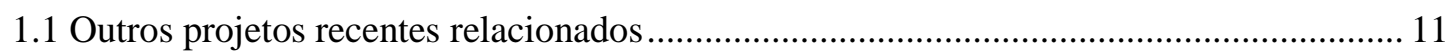

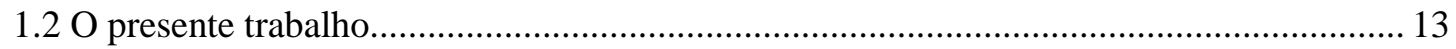

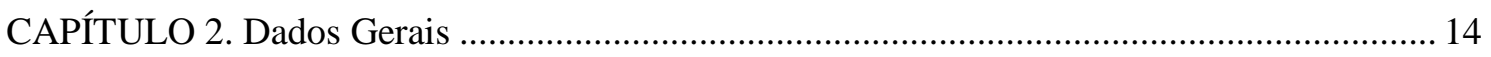

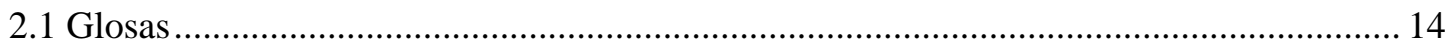

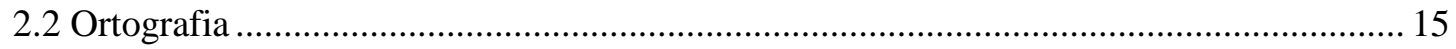

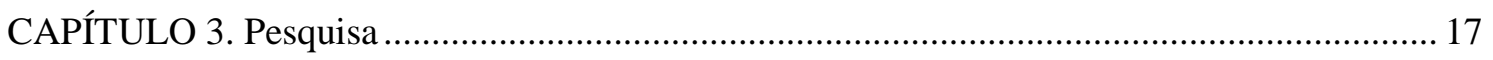

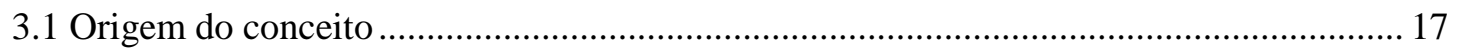

3.2 Aspecto, Tempo e Modo na Linguística Moderna ............................................................. 19

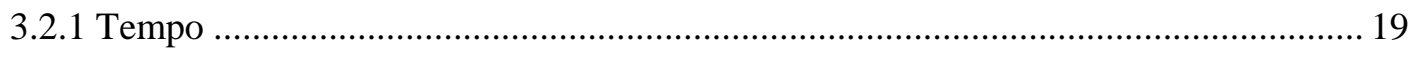

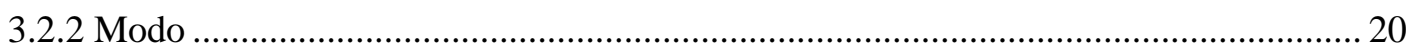

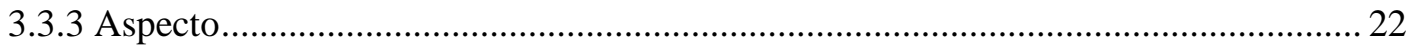

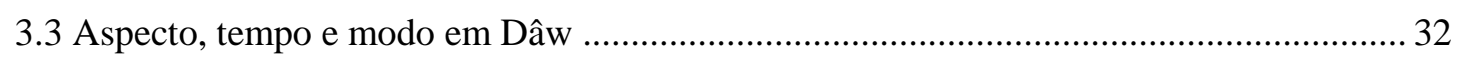

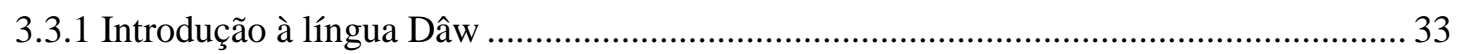

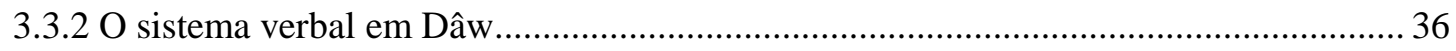

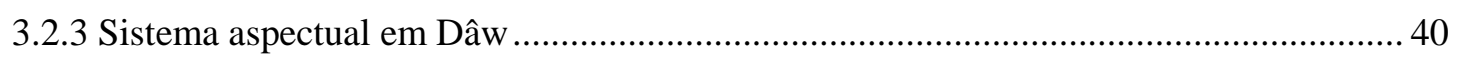

3.3.4 Aspecto na família Nadahup e no Sprachbund do Alto Rio Negro ................................ 44

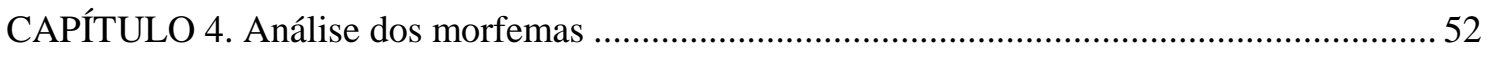

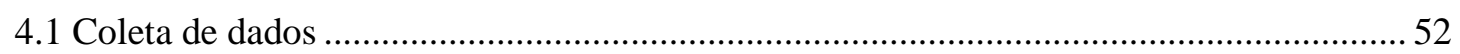

4.2 Descrição individual dos 15 morfemas de aspecto em Dâw ................................................ 54

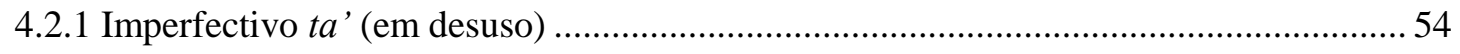

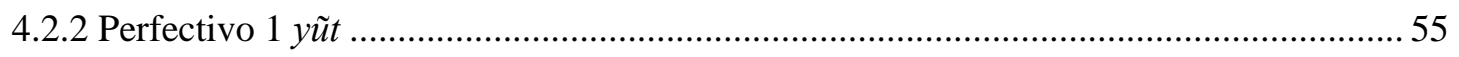

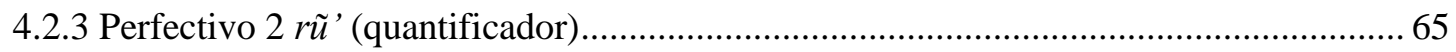

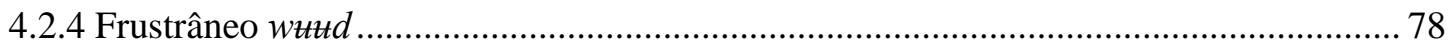

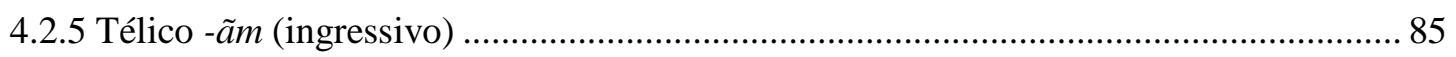


4.2.6 Durativo xâd e pontual dâr.

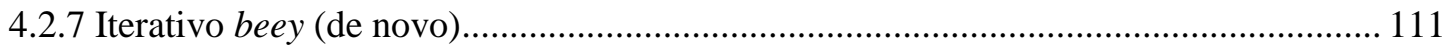

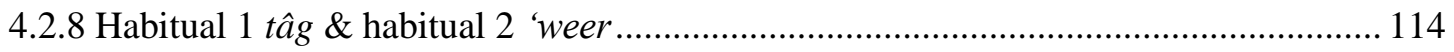

4.2.9 Progressivo 1 yow (perfectivo súbito/direto)................................................................ 123

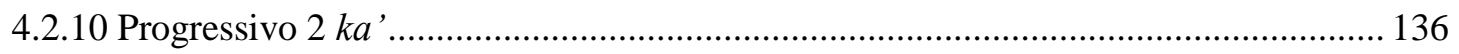

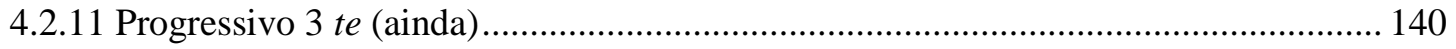

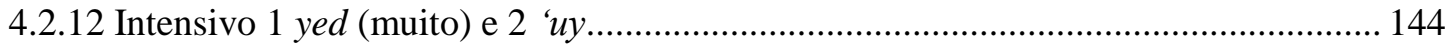

4.3 Outras considerações sobre os marcadores de aspecto...................................................... 146

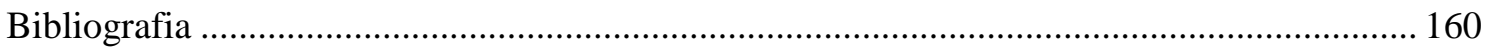

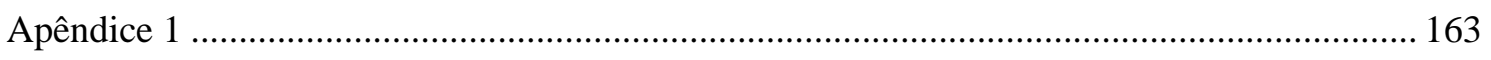

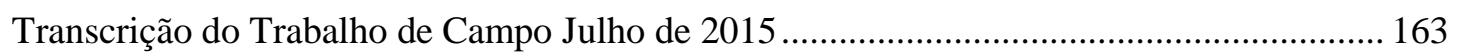

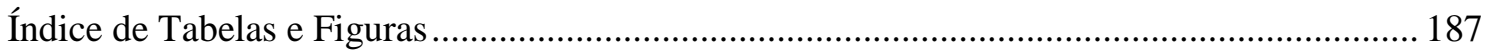




\section{RESUMO}

CARVALHO, Maurício Oliveira Pires de. ASPECTO VERBAL NA LÍNGUA DÂW, 2016187 f. Dissertação (Mestrado) - Faculdade de Filosofia, Letras e Ciências Humanas, Universidade de São Paulo, 2016.

Este projeto tem o objetivo de descrever e analisar a morfologia de aspecto no idioma indígena amazônico Dâw (aprox. 100 falantes, pertencente à família Nadahup, anteriormente conhecida como Makú) em relação à descrição dada na única gramática disponível do idioma, Gramática e Fonologia Dâw, publicada por Silvana Martins em 2004. Naquela obra, a autora descreve 15 morfemas pós-verbais que chama de 'marcadores de aspecto', atribuindo funções aspectuais a cada um. Neste trabalho, analisamos a fundo essa afirmação, pondo em dúvida e reanalisando os 15 morfemas ditos aspectuais pela autora, com o intuito de verificar se a descrição da autora está correta. Os novos dados e análises confirmaram apenas parcialmente a análise de Martins, revelando na maioria dos casos que os morfemas desempenham funções bastante divergentes das propostas pela autora.

Neste trabalho propomos uma nova classificação para a função desses morfemas, mediante à realização de trabalhos de campo junto aos falantes nativos do idioma no município de São Gabriel da Cachoeira, noroeste da Amazônia.

As novas amostras dos trabalhos de campo e análise de outros materiais revelaram que alguns morfemas caíram em desuso, outros não possuem valor aspectual apreciável e outros são morfemas port-manteau tempo-aspecto-modais. Ainda outros possuem outras características, como quantificação dos argumentos do verbo (categoria que como veremos está bastante associada a aspecto) ou função adverbial.

Os morfemas com valor aspectual revelaram ter efeitos diferentes com classes de verbos diferentes, como o morfema perfectivo, que com verbos ativos possui função perfectiva de ação concluída no passado, mas com verbos estativos possui valor de aspecto perfeito, ou seja, estado atual causado por transformação no passado. Também incluímos comparações com os sistemas aspectuais de outras línguas do Alto Rio Negro e com línguas tipologicamente similares do mundo inteiro. 


\section{ABSTRACT}

CARVALHO, Maurício Oliveira Pires de. VERBAL ASPECT IN THE DAW

LANGUAGE 2016, 187 pages. Master Degree Thesis - Faculty of Philosophy, Languages and Literature and Human Sciences, University of Sao Paulo, Brazil, 2016.

This project aims to describe and analyze aspect morphology in the Amazonian indigenous language Dâw (approx. 100 speakers, belonging to Nadahup family, formerly known as Makú) in relation to the description found in the only available grammar on the language, Gramática e Fonologia Dâw, published by Silvana Martins in 2004. In that work, the author describes 15 post-verbal morphemes which she calls 'aspect markers' assigning distinct aspectual functions to each of them. In this paper, we tested that assertion, questioning and eventually reanalyzing the alleged aspectual morpheme, in order to verify whether the description provided by that author is correct. The new data confirmed Martins analysis only partially, revealing in most cases that the morphemes play roles that diverge quite significantly from the author's description.

In this paper we propose a new classification for these morphemes, based on the data collected during a field work in July 2015 with native Dâw speakers in São Gabriel da Cachoeira, in the northwestern Brazilian Amazon.

The new field work samples and an in-depth analysis of other source materials revealed that some morphemes have become obsolete, others have no discernible aspectual value, and others are port-manteau time-aspect-modal morphemes. Some display features such as quantification of verbal arguments (as we shall see, quantifications is intertwined with aspect) or play adverbial roles.

The morphemes with aspectual value were shown to behave differently depending on verbal classes, such as the perfective morpheme, which with active verbs has a perfective function, indicating action completed in the past, but with stative verbs it indicates perfect aspect, i.e., current state caused by transformation in the past. A comparison with the aspectual systems of other Upper Rio Negro languages as well as with other typologically similar languages worldwise is also provided. 


\section{AGRADECIMENTOS}

Antes de tudo agradeço a meus pais, Antonio Carlos e Regina Glória.

Gostaria de agradecer especialmente à minha orientadora Luciana Storto, sem a qual minha viagem pela linguística acadêmica teria sido impossível.

Também agradeço aos professores Esmeralda Negrão, Ana Paula Scher, Julio Barbosa, Eliane Grolla, ministrantes das aulas de mestrado no curso regular, por sua extensa ajuda em todo tipo de questões linguísticas.

Agradeço também aos colegas Wallace Andrade e Jessica Costa que participaram do projeto de Dâw e, juntamente com a professora Storto coletaram dados adicionais para a minha pesquisa, bem como Lucas Cavalini Barboza, que acompanhou a mim e à professora no trabalho de campo de julho de 2015 na Amazônia.

E, finalmente, agradeço aos Dâw que conheci no trabalho de campo, os consultores Mateus, Jonas, Sília, Ester, Deolinda, Valteirzinho, Tatiane, Valdemar, e especialmente à Dna. Auxiliadora Fernandes da Silva, que tanta atenção devotou aos meus interesses gerais sobre seu idioma além do escopo imediato desta pesquisa, e que me convidou para observar o primeiro dia do Festival Anual das Comunidades Indígenas da região, no meu último dia em São Gabriel, onde pude observar mais aspectos da cultura indígena da região e interagir com membros de outras etnias, como os Tukano, Hup e Baniwa.

Este trabalho é dedicado à minha filha Sofia. 


\section{CAPÍTULO 1. Introdução}

Este projeto foi financiado pela CAPES e orientado pela Profa. Luciana Raccanello Storto e está inserido no programa de pós-graduação em Semiótica e Linguística Geral do Departamento de Linguística da Universidade de São Paulo.

\subsection{Outros projetos recentes relacionados}

\section{Documentation of Dâw, a Nadahup language of Brazil}

O presente projeto de mestrado se segue ao projeto internacional coordenado pelas professoras doutoras Luciana R. Storto, da Universidade de São Paulo, e Patience Epps, da Universidade do Texas (EUA), de descrição e documentação da língua Dâw Documentation of Dâw, a Nadahup language of Brazil.

A equipe daquele projeto era formada pelas duas professoras supracitadas e pelos alunos de mestrado Jéssica C. Costa e Wallace Andrade, pós-graduandos do Departamento de Linguística DL-USP.

Também houve colaboração de dois alunos de Iniciação Científica, alunos graduandos do DL: Clariana Assis e Lucas Cavalini Barboza. Aquele projeto, que se iniciou em fevereiro de 2013 e terminou em fevereiro de 2014 visava à documentação da língua e da cultura Dâw e à criação de um corpus linguístico, composto por áudio e vídeo, abrangendo uma variedade de discursos e gêneros, e um léxico. Os principais objetivos daquele projeto foram o treinamento dos falantes da língua Dâw nas práticas de documentação, com gravação, transcrição, organização de dados, o estabelecimento das bases para um corpus de textos narrativos, músicas, rituais e de práticas manufatureiras que os integrantes da comunidade gostariam de documentar para futuras gerações, a compilação de um léxico da língua e a descrição gramatical da língua Dâw para aprimorar e aprofundar a descrição realizada por Martins (2004). 
Os dados do léxico foram armazenados e transcritos na ferramenta FieldWorks Language Explorer - FLEx, um programa do Summer Institute of Linguistics (SIL), que ajuda na documentação de línguas e na organização dos dados coletados em trabalho de campo, e foi utilizado para a presente dissertação. O programa (figura 1 abaixo) ajudou na compilação de uma base de dados lexicais e tem a capacidade de receber textos que podem ser interlinearizados a partir da base lexical; assim, em cada frase dos textos, é possível inserir novos lexemas, e o programa é capaz de analisar palavras morfema por morfema, alinhando lexemas com informações gramaticais, glosas e a tradução. Foi estipulado com a comunidade de falantes que a base de dados utilizaria as categorias definidas por Martins (2004) em sua lista de abreviaturas, e que qualquer diferença ou modificação seria adicionada em um campo especial de cada entrada lexical. Os dados coletados em campo pelo projeto foram identificados como tal, de maneira que é possível extrair da base de dados os itens identificados e analisados por Martins (2004) daqueles coletados pelos membros do projeto. O trabalho de alimentação do banco de dados da língua Dâw foi realizado pelos pesquisadores Luciana Storto, Wallace Andrade, Clariana Assis, Patience Epps e alunos. Atualmente o banco de dados possui 1655 entradas lexicais.

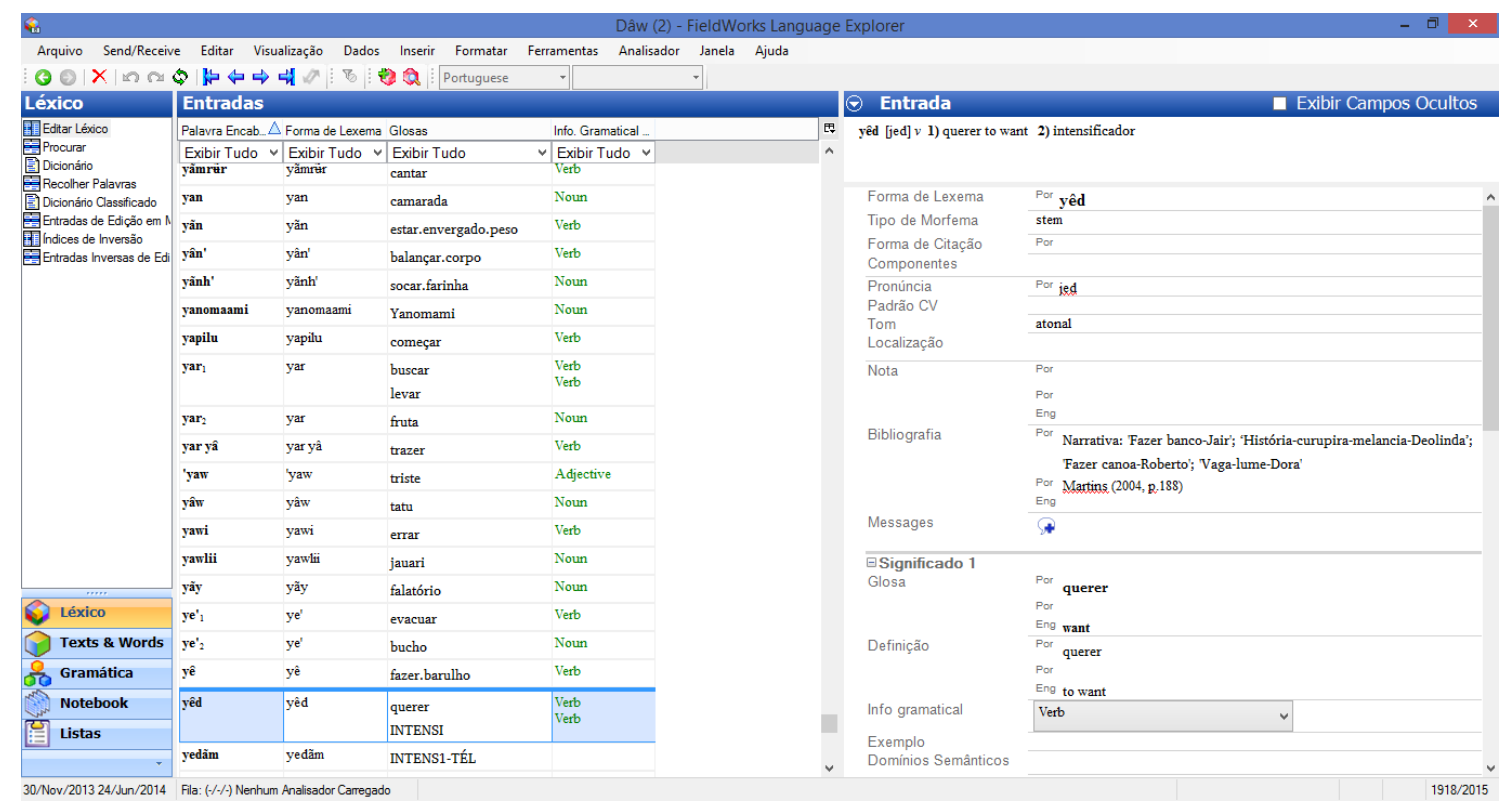

Figura 1 - tela do léxico Dâw aberto no FieldWork Language Explorer 


\section{$1.2 \mathrm{O}$ presente trabalho}

Esta dissertação envolve a pesquisa sobre o aspecto verbal na língua Dâw, especificamente a análise dos 15 morfemas chamados de aspectuais na gramática de Silvana Martins (2004) com o intuito de questionar, confirmar ou negar a natureza aspectual desses morfemas, bem como propor explicações e análises alternativas com relação à descrição da autora.

Este projeto teve os seguintes objetivos:

i) estudar a categoria do aspecto verbal sob a ótica formal nas áreas da semântica, sintaxe e morfologia, identificando a função e uso de cada um dos morfemas chamados de aspectuais;

ii) determinar quais morfemas coocorrem com quais tipos de verbo (ativos, estativos, cognitivos, etc.) e como reagem à negação;

iii) avaliar as hipóteses descritivas e explicativas sobre os morfemas aspectuais verbais identificadas por Martins (2004), a primeira e até o presente momento única gramática do idioma Dâw.

Dado o grande número de morfemas e a grande quantidade de permutações possíveis para analisar todas as hipóteses e interações entre características para cada morfema, algumas estratégias foram priorizadas.

Tomamos o cuidado de testar todos os 15 morfemas com pelo menos verbos ativos e não ativos (estativos, os 'adjetivos' da língua, e alguns cognitivos e de ligação), analisando que nuance aspectual (se houver) cada morfema tem com um e o outro tipo. Analisamos também, prioritariamente, o efeito da negação sobre o morfema de aspecto, bem como se o morfema negador pode vir afixado ao verbo ou ao morfema aspectual, e que diferença semântica isso faz. 


\section{CAPÍTULO 2. Dados Gerais}

\subsection{Glosas}

\section{Abreviaturas usadas nas glosas deste trabalho:}

\begin{tabular}{|l|l|}
\hline AFET & $\begin{array}{l}\text { morfema -üuy 'afetado', sufixo nominal marcador de objetos [+definidos + } \\
\text { animados] em Dâw. }\end{array}$ \\
\hline PRES & presente \\
\hline FUT & futuro \\
\hline PASS & passado \\
\hline 1sg, 2pl & $\begin{array}{l}\text { primeira pessoa singular, segunda pessoa plural, etc., marcando os } \\
\text { pronomes pessoais básicos do idioma }\end{array}$ \\
\hline NEG & morfema de negação \\
\hline PERF & perfectivo \\
\hline IMP & imperfectivo \\
\hline FRUST & frustrâneo \\
\hline TEL & télico \\
\hline PONT & pontual \\
\hline HAB & habitual \\
\hline ITER & iterativo \\
\hline PROG & progressivo \\
\hline INTS & intensivo \\
\hline MOV & movimento, morfema $d o ̂ o '$ indicador de movimento \\
\hline CAUS & causativo, morfema $d \hat{o} o$ ' causativizador \\
\hline $\begin{array}{l}\text { EVID } \\
\text { REPORT }\end{array}$ & evidencial reportativo $(m a \tilde{r})$ \\
\hline FOC & foco, focalizado, com ênfase \\
\hline
\end{tabular}

Tabela 1 - abreviaturas

Os diversos morfemas analisados são numerados quanto têm o mesmo nome, perfectivo 1, 2, 3 = PERF1, PERF2, PERF3, etc. A nomenclatura de Martins foi mantida. 


\subsection{Ortografia}

Neste trabalho, utilizamos a ortografia da língua Dâw para registrar nossos dados originais coletados em campo. As fontes bibliográficas sobre o idioma Dâw foram compiladas principalmente em dois sistemas de transcrição. Martins (2004) e algumas fontes mais antigas tendem a usar uma transcrição fonêmica via alfabeto fonético internacional (IPA), mas algumas obras mais recentes, como as dissertações acadêmicas de Jéssica Costa e Wallace Andrade (ambas de 2014) e amostras de trabalhos de campo usam um sistema ortográfico desenvolvido pelos professores da comunidade em conjunto com Valteir Martins, hoje usado na escola dos Dâw e em algumas obras e cartilhas no idioma. Todo o material originalmente em IPA foi transformado em ortografia comum do idoma no presente trabalho.

A equivalência entre os grafemas do sistema ortográfico (doravante designado de 'ortografia padrão') e os símbolos do Alfabeto Fonético Internacional (IPA) está representada nas tabelas 2 (consoantes) e 3 (vogais) abaixo:

O símbolo IPA está sem parênteses e o símbolo ortográfico entre parênteses

\begin{tabular}{|c|c|c|c|}
\hline $\mathrm{p}(\mathrm{p})$ & $\mathrm{t}(\mathrm{t})$ & $\mathrm{c}(\mathrm{c})$ & $\mathrm{k}(\mathrm{k})$ \\
\hline \multirow[t]{2}{*}{ b (b) } & $\mathrm{d}(\mathrm{d})$ & f (j) & $\mathrm{g}(\mathrm{g})$ \\
\hline & & $\int(\mathrm{s})$ & $\mathrm{x}(\mathrm{x})$ \\
\hline $\mathrm{m}(\mathrm{m})$ & $\mathrm{n}(\mathrm{n})$ & $\mathrm{n}(\mathrm{nh})$ & $\eta(g n)$ \\
\hline \multirow[t]{3}{*}{$\mathrm{m} ?$} & n? & n? & \\
\hline & $1(1)$ & & \\
\hline & $1 ?$ & & \\
\hline $\mathrm{w}(\mathrm{w})$ & & $\mathrm{j}(\mathrm{y})$ & \\
\hline w? & & j? & \\
\hline
\end{tabular}

Tabela 2 - Consoantes 
Todas as consoantes glotalizadas são grafadas na ortografia padrão com um apóstrofe (') antes da consoante, se esta ocorrer em início de palavra, ou após a consoante, se esta não for inicial.

$\begin{array}{ccc}\text { i (i) } & \text { u (u) } & \text { u (u) } \\ \text { e (ê) } & \gamma(\hat{a}) & \text { o (ô) } \\ \varepsilon(e) & \text { a (a) } & \text { o (o) } \\ & \text { Tabela 3 - Vogais } & \end{array}$

As três vogais mais altas e mais baixas quando nasais fonemicamente são marcadas com um til ( ). Vogais com tom são duplicadas. Tom ascendente é ' (acento agudo) na última vogal se houver par mínimo, e tom descendente não é marcado. Quando a vogal média tem tom, o circunflexo é marcado nas duas vogais.

Uma observação importante a ser feita acerca da grafia do idioma é quanto ao tom, que pode variar na mesma palavra de acordo com certas regras. Portanto, uma mesma palavra pode aparecer grafada com a sua vogal dupla (tonal ascendente ou descendente) ou simples (atonal). A nasalização das vogais ocorre automaticamente na adjacência imediata de consoantes nasais; mesmo assim a convenção ortográfica do idioma marca as vogais previsivelmente nasais com o til. 


\section{CAPÍtulo 3. Pesquisa}

\subsection{Origem do conceito}

A palavra aspecto deriva do latim aspectus, de ad- (preposição indicadora de movimento) e spectus (olhar, observação, visão), significando algo como 'direção em que se olha, olhar para algo'.

A acepção gramatical do termo na literatura ocidental teve origem em traduções de obras de linguística eslava escritas em russo no século 17, em que o termo eslavo eclesiástico видъ ([vid'], Meletij Smotrićkyj 1619, relacionado ao verbo russo видеть [videt'] 'ver', polonês wiedzieć 'saber', da raiz indo-europeia do nosso verbo 'ver' < Latin videre) foi usado para descrever o aspecto verbal eslavo, inspirado pelo grego $\varepsilon \tilde{i} \delta o \varsigma$ ([eidos], visão, aspecto, relacionado ao verbo oîं $\delta \alpha$ [oida] 'ver', $\varepsilon i ̋ \delta o \mu \alpha l$ [eidomai] 'ver, perceber', da mesma raiz indo-europeia) usado já por gramáticos da Antiguidade, como Dionísio da Trácia (séc. 2 a.C.), para descrever fenômenos aspectuais do grego.

No entanto, a análise do fenômeno precede a criação do termo, remontando à antiguidade.

Os gramáticos gregos antigos classificaram as formas tempo-aspectuais dos verbos do grego clássico em duas grandes categorias: horismenoi (definidos) e aoristoi (indefinidos), subdividindo os do primeiro grupo em duas classes, uma dotada de extensão, com os tempos presente e perfeito, e outra privada de extensão, o perfeito.

No Latim, o gramático Varrão parece ter sido o primeiro gramático a notar explicitamente a categoria de aspecto no idioma, ao distinguir entre tempora infecta e tempora perfecta (tempos imperfeitos e perfeitos).

As análises da Antuguidade Clássica, contudo, ainda não distinguiam a noção de aspecto completamente da noção de tempo. 
O termo 'aspecto' bem como o termo alemão Aktionsart (li. 'tipo de ação') eram usados no século 19 para fenômenos similares, praticamente como sinônimos. Em 1908 o eslavista sueco Sigurd Agrell traçou pela primeira vez uma distinção entre ambos (apud Krifka 2002/ apud Hock 2003):

"Por Aktionsart não entendo [...] as duas categorias principais do verbo eslavo, que são as formas perfeitas e imperfeitas (perfectivo e imperfectivo) - estas eu denomino Aspectos. Com o termo Aktionsart eu designo funções semânticas dos compostos verbais até agora não estudadas - e muito menos classificadas [...] que exprimem com mais exatidão como a ação é realizada, e marcam o modo e a maneira de sua realização" 1

(Agrell, 1908)

Essa definição encontrou ampla difusão na eslavística, embora para o aspecto semântico tenham sido sugeridos outros termos, como Verbalcharakter ('caráter verbal') pelo eslavista Alexander Isačenko (Isačenko, 1962), e Zeitart ('tipo temporal'). Contudo, no mundo da linguística, o termo Aktionsart continuou a ser usado amplamente tanto para o aspecto lexical visto como típico de um verbo quanto (especialmente na filologia clássica) para a classificação das distinções semânticas de diversas conjugações verbais (Krifka/ Hock 2002/2003).

Na linguística moderna se difundiu finalmente a distinção entre o aspecto em referência àquele indicado por flexão morfológica, dito aspecto gramatical, e o Aktionsart, ou aspecto lexical, como termo referente à morfologia derivacional e usado para a classificação semântica dos verbos (Krifka/ Hock 2002/2003).

Apenas nos anos 1970 o termo Aktionsart se dissociou da sua conexão exclusiva com a morfologia derivacional e passou a cobrir as classes aspectuais, como dinamicidade,

\footnotetext{
1 'Unter Aktionsart verstehe ich, wie in der Einleitung schon hervorgehoben worden ist, nicht die beiden Hauptkategorien des slawischen Zeitwortes,

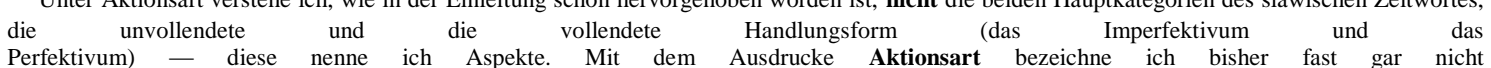
Perfektivum) — diese nenne ich Aspekte. Mit dem Ausdrucke Aktionsart bezeichne ich bisher fast gar nicht wird, die Art und Weise ihrer Ausführung markieren'
} 
durabilidade e telicidade. Foi nesse sentido que o termo entrou na linguística dos EUA e, portanto, na tradição gerativista atualmente difundida (Filip, 1991, p. 726).

\subsection{Aspecto, Tempo e Modo na Linguística Moderna}

O aspecto (ao menos o gramatical) pertence ao grupo de categorias 'TAM' (tempo, aspecto e modo), que frequentemente se exprimem morfologicamente de modo interrelacionado nos verbos das línguas do mundo, à parte de outras categorias e grupos de categorias, como as designadas pela letra grega $\Phi$ ('fi', pessoa, gênero/classe e número) e evidencialidade.

\subsubsection{Tempo}

O tempo gramatical (tense) é uma marcação de um evento ao longo de uma linha temporal (Reichenbach, 1947). A semântica temporal, segundo Reichenbach (1947), se define por três momentos:

1 - o momento da fala (MF)

2 - o momento do evento (ME)

3 - o momento da referência (MR)

E por duas relações de ordenamento: anterioridade e simultaneidade.

\begin{tabular}{|llll|}
\hline \multicolumn{1}{|r}{$\begin{array}{c}\text { Relações } \\
\text { temporais }\end{array}$} & Tempo & $\begin{array}{r}\text { Designação } \\
\text { tradicional }\end{array}$ & Exemplo \\
1. E-R-F & $\begin{array}{l}\text { passado } \\
\text { anterior } \\
\text { passado } \\
\text { simples }\end{array}$ & passado perfeito & Eu tinha lido o livro no final no ano. \\
2. E,R-F & $\begin{array}{l}\text { passado } \\
\text { posterior }\end{array}$ & - & Eu li o livro. \\
3.a R-E-F & passado & -- & Eu não sabia que ele venceria (ontem) \\
3.b R-F,E & & & Eu não sabia que ele estaria aqui. (neste \\
\hline
\end{tabular}




\begin{tabular}{|c|c|c|c|}
\hline & posterior & & momento) \\
\hline 3.c R-F-E & $\begin{array}{l}\text { passado } \\
\text { posterior }\end{array}$ & -- & Eu não sabia que ele viria. (amanhã) \\
\hline 4. $\mathrm{E}-\mathrm{F}, \mathrm{R}$ & $\begin{array}{l}\text { presente } \\
\text { anterior }\end{array}$ & presente perfeito & Eu li o livro (I have read the book). \\
\hline 5. F,R,E & $\begin{array}{l}\text { presente } \\
\text { simples }\end{array}$ & presente & Eu vejo Pedro. \\
\hline 6. $\mathrm{F}, \mathrm{R}-\mathrm{E}$ & $\begin{array}{l}\text { presente } \\
\text { posterior }\end{array}$ & futuro simples & Eu verei Pedro. \\
\hline 7a F-E-R & futuro anterior & futuro perfeito & Eu terei lido o livro no fim do ano. \\
\hline 7.b F,E-R & futuro anterior & futuro perfeito & $\begin{array}{l}\text { Pedro terá consertado o carro hoje à noite } \\
\text { (já consertou) }\end{array}$ \\
\hline 7.c E-F-R & futuro anterior & futuro perfeito & $\begin{array}{l}\text { Eu terei consertado o carro hoje à noite. } \\
\text { (só consertando) }\end{array}$ \\
\hline 8. $\mathrm{F}-\mathrm{R}, \mathrm{E}$ & futuro simples & futuro simples & Eu verei Pedro amanhã. \\
\hline 9. $\mathrm{F}-\mathrm{R}-\mathrm{E}$ & $\begin{array}{l}\text { futuro } \\
\text { posterior }\end{array}$ & & Eu vou visitá-lo. \\
\hline
\end{tabular}

Tabela 4 - Relações temporais de Reichenbach

\subsubsection{Modo}

É importante entendermos a categoria de modo também, para podermos distingui-la das categorias de aspecto e tempo. O modo geralmente reflete considerações sobre a realidade ou irrealidade de uma ação, bem como noções como capacidade/permissão (poder fazer) e dever (ter que fazer, dever fazer).

Por exemplo, a proposição 'a terra é plana' corresponde ao conjunto de mundos possíveis em que a terra é de fato plano. Assim, expressões modais, como 'dever' e 'poder', são analisados como quantificadores de um conjunto de mundos possíveis. A chamada base modal indica o conjunto de mundos acessíveis: Por exemplo, na sentença 'Pedro deve estar ganhando muito dinheiro', a base modal é o conhecimento que o orador tem no mundo real. Portanto, o conjunto de mundos acessíveis é definido pelas informações que o falante tem sobre Pedro. Suponhamos, por exemplo, que o falante sabe que Pedro tenha acabado de comprar um novo carro de luxo e alugou um apartamento enorme. $\mathrm{O}$ falante também sabe que Pedro é uma pessoa honesta, vindo de família humilde e não joga na loteria. $\mathrm{O}$ conjunto de mundos acessíveis é então o 
conjunto de mundos em que todas essas proposições que o falante sabe sobre Pedro são verdadeiras.

As noções de necessidade e possibilidade são definidas da seguinte maneira: uma proposição $\mathrm{P}$ decorre necessariamente do conjunto de mundos acessíveis, se todos os mundos acessíveis fazem parte de $\mathrm{P}$ (isto é, se P é verdade em todos esses mundos). Em relação ao exemplo no parágrafo acima, isto significa que em todos os mundos que são definidos pelo conhecimento do falante sobre Pedro, é o caso que Pedro ganha muito dinheiro (assumindo que não há outra explicação para a riqueza dele). De uma maneira semelhante, uma proposição $\mathrm{P}$ é possível de acordo com o conjunto de mundos acessíveis (isto é, a base modal), se alguns destes mundos são parte de P (Kratzer 1991, Kaufmann et al. 2006 e Portner 2009).

Em muitas línguas, as categorias modais são expressas pela morfologia verbal, seja por afixos ou por verbos auxiliares. Se estes marcadores de modalidade são obrigatórios em um idioma, eles são chamados de marcadores de modo. Exemplos bem conhecidos de modo em algumas línguas europeias são indicativo (geralmente o modo 'não marcado'), subjuntivo, condicional, imperativo e optativo. Em boa parte das línguas do mundo, a morfologia verbal não transmite apenas informações sobre modalidade, mas também sobre outras categorias, como pessoa e número do sujeito, além de, como aludido acima, aspecto e tempo.

Verbos auxiliares modais, tais como as palavras inglesas can, could, must, will, etc., bem como advérbios, complementizadores e conjunções também são usados para expressar modalidade.

Ainda no campo de modo, é importante distinguirmos entre realis e irrealis, que abrangem as categorias modais citadas acima.

Os modos realis se referem a situações reais, consideradas reais ou cuja existência é inferida. O modo realis por excelência é o indicativo. Em contraste, os modos classificados como irrealis referem-se a situações cuja veracidade não se conhece. Modos irrealis comuns são o condicional, que expressa algo que poderia acontecer sob 
uma determinada condição, e o subjuntivo, que expressa preferências do falante quanto ao que deveria ser ou ocorrer, bem como hipóteses.

Contrafactuais referem-se a coisas que são contrárias à situação real. Em idiomas europeus, contrafactuais são expressos em sentenças com a conjunção 'se', usando um tempo verbal que normalmente se refere a um tempo anterior ao tempo realmente semanticamente referido na cláusula iniciada por 'se'. Por exemplo, 'se eu soubesse disso, eu não teria que perguntar' contém o contrafactual 'se eu soubesse' que remete para o tempo presente, apesar da forma do verbo, e que nega a proposição 'eu sei disso'.

Outro contraste importante é entre modalidade epistêmica vs. deôntica. Os modos epistêmicos são usados para indicar a possibilidade ou necessidade de alguma informação, o que pode ser interpretado como uma indicação de inferência ou algum outro processo de raciocínio usado para se chegar a uma conclusão, como em 'ele pode estar lá', ou 'ele deve estar lá' no sentido de especulação. Um dos efeitos da utilização de um modal epistêmico é uma redução geral do compromisso do falante para com a veracidade da frase contendo o modal.

Em contraste, a modalidade deôntica lida com a possibilidade e necessidade em termos de liberdade para agir (incluindo capacidade, permissão,e dever), como 'ele pode ir' (no sentido de capacidade ou permissão) ou 'ele tem que ir'. No português, como em muitas outras línguas, algumas das mesmas palavras são usadas tanto para modalidade deôntica como para a modalidade epistêmica, e o significado depende do contexto, como se observa no uso deôntico ou epistêmico do verbo 'poder' nos exemplos acima.

\subsubsection{Aspecto}

Finalmente podemos nos concentrar no tema principal desta dissertação, o aspecto.

O aspecto gramatical é definido por Comrie (1976, p. 3) como 'uma maneira de ver a estrutura temporal interna de uma situação' ('aspects are different ways of viewing the internal temporal constituency of a situation'). Uma formulação mais simples poderia 
ser, segundo o presente autor, que aspectos expressam a relação da ação verbal com o fluir do tempo.

Os principais aspectos listados por Comrie são os seguintes (Tabela 5):

\begin{tabular}{|l|}
\hline Perfectivo / imperfectivo \\
\hline Progressivo / não progressivo \\
\hline Pontual / habitual \\
\hline Télico / atélico \\
\hline Estativo / dinâmico \\
\hline $\begin{array}{l}\text { Perfeito (passado \& presente, recente, } \\
\text { situação atual devida a evento passado) }\end{array}$ \\
\hline Tabela 5 - Principais aspectos em Comrie (1976)
\end{tabular}

A progressividade e a habitualidade são vistas como sub-categorias da imperfectividade:

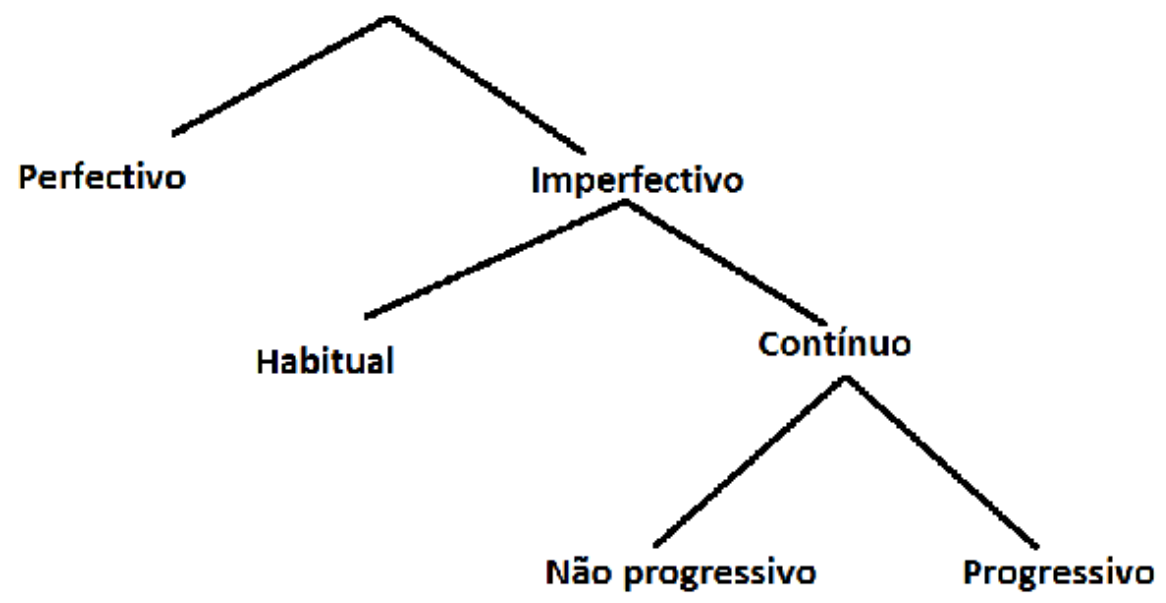

Figura 2 - imperfectividade e suas sub-categorias (Comrie, 1976)

A distinção mais comum de aspecto gramatical é entre perfectivo - instância específica de uma ação unitária e concluída - e imperfectivo - ação contínua, repetida, prolongada e/ou sem conclusão expressa (Comrie, 1976). O aspecto perfectivo seria um ponto (ou uma 'bolha', segundo Comrie, com dimensões, mas claramente limitada) na linha do tempo concebida pelo falante, sem estrutura temporal ou duração apreciáveis, ao passo 
que o aspecto imperfectivo seria um segmento dessa linha, dotado, portanto, de duração apreciável em relação à linha do tempo ${ }^{2}$, embora possa notar eventos prolongados em caso de argumentos plurais do verbo, como 'eles fecharam cada porta uma por uma' (Comrie, 1976, p. 18).

Comrie conclui (p. 21) que a perfectividade envolve a falta de referência explícita à estrutura temporal de uma situação, ao invés de explicitamente indicar a falta de uma estrutura temporal interna, sendo portanto possível usar o perfectivo para situações dotadas de complexidade interna, com duração prolongada ('a greve durou cinco dias') ou diversas fases distintas ('cada visitante touxe um pouco de lama para o quarto', ou 'eles fecharam as portas uma por uma'), contando que a situação como um todo seja reduzida a uma única entidade. A figura 3 abaixo ilustra a diferença entre o perfectivo e o imperfectivo.

perfectividade:

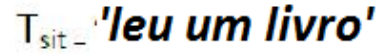

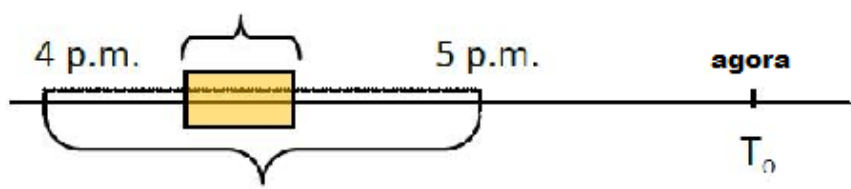

$\mathrm{T}_{\mathrm{R}}$

imperfectividade:

\section{$\mathrm{T}_{\mathrm{sit}}=$ 'estava lendo/lia um livro}

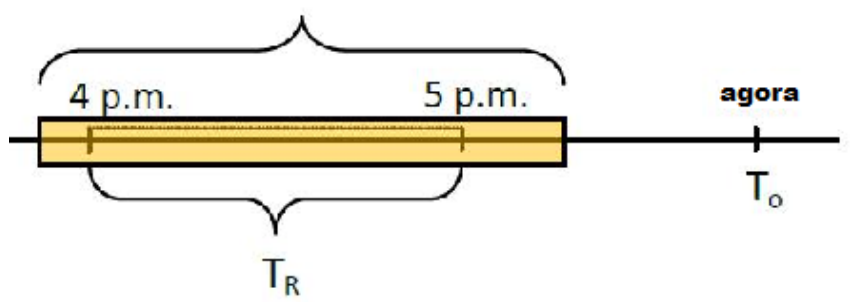

Figura 3 - perfectividade vs. imperfectividade

(legenda: $\mathrm{T}_{\text {sit }}$ - tempo da situação, $\mathrm{T}_{\mathrm{R}}$ - tempo de referência, $\mathrm{T}_{0}$ - tempo da fala)

\footnotetext{
22 'While it is incorrect to say that the basic function of the perfective is to represent an event as momentary or punctual, there is some truth in the view that the perfective, by not giving direct expression to the internal structure of a situation, irrespective of its objective complexity, has the effect of reducing it to a single point' (Comrie, 1976, pp. 17, 18).
} 
Geralmente se afirma que o perfectivo denota uma ação concluída, mas o termo mais exato seria 'completa' ${ }^{3}$, pois ações que foram interrompidas também podem ser expressas como perfectivas.

Comrie e outros autores notam que o efeito da aplicação da morfologia perfectiva de uma língua muda de acordo com a classe verbal em certos idiomas. Por exemplo, 'eu conheci Pedro' não significa a perfectividade do verbo cognitivo 'conhecer' (ação concluída de conhecer) no passado, delimitada, e sim uma mudança de estado, algo que Comrie chama de 'ingressivo', como se observa em 'saber' ('eu soube do acidente'), e nos verbos estativos do chinês, como em ta gāo (ele é alto), que com o marcador de perfectividade le, ta gāo le passa a ser ingressivo ou perfeito: 'ele ficou alto', 'ele está alto'. Essa observação será, como explicaremos adiante, de importância central para esta dissertação.

Dada a definição de perfectividade acima, a imperfectividade (geralmente menos marcada na maioria das línguas) é definida como fazendo referência à estrutura temporal interna das situações.

Dentro da imperfectividade, o aspecto habitual se distingue do iterativo e da mera noção de repetitividade em que estes últimos dois conceitos podem ser aplicados a situações que se repetem em apenas uma sessão de eventos que podem ser vistos como um todo, como 'ele tossiu cinco vezes', que é uma sentença iterativa, mas não habitual, e interessentemente, como é vista como um único todo, é expressa tipicamente pelo perfectivo. Além disso, a habitualidade muitas vezes não envolve qualquer repetição ou iteração, como I used to live here 'eu costumava morar aqui'. A habitualidade, portanto, pode ser definida como uma ação bastante extensa por um período de tempo, a ponto de se tornar uma característica desse período.

Outra grande sub-divisão da imperfectividade é a progressividade. Nem todas as línguas denotam claramente a progressividade, que em muitas línguas não precisa de marcação explícita, ou seja, a forma verbal não progressiva pode ter leitura progressiva. O inglês, o espanhol e o português são línguas em que a progressividade tende a ser expressa pela

\footnotetext{
${ }^{3} \mathrm{O}$ perfectivo na terminologia de Comrie seria 'complete' e não 'completed', traduzidos aqui por 'completa' e 'concluída'.
} 
morfologia específica; outros idiomas europeus tendem a expressar progressividade apenas em circunstâncias limitadas, por meio de advérbios ou expressões preposicionais. Comrie define progressividade como, 'imperfectividade não determinada por habitualidade'. É difícil distingui-la da simples imperfectividade, exceto que a progressividade tende a enfatizar o prolongamento ou a continuação do evento por um período mais longo do tempo de referência do que a mera imperfectividade não progressiva.

Um contraste adicional importante que devemos mencionar aqui é entre duratividade e pontualidade. Uma ação durativa é meramente uma ação cuja duração maior na linha do tempo é enfatizada pelo falante, ao passo que uma ação pontual é concebida como durando uma porção ínfima de tempo (Comrie, 1976). Nisso os dois conceitos parecem paralelos e pouco distinguíveis dos próprios conceitos de imperfectividade e perfectividade, mas se trata de outra noção, pois aqui já tratamos de verbos cuja semântica parece ser inerentemente pontual ou durativa, como espirrar ou tossir (pontuais), ou ficar em pé ou ficar sentado, vistas como situações tipicamente prolongadas, mas que podem aparecer em predicados perfectivos (eu estou tossindo, eu costumava tossir) ou imperfectivos (eu fiquei sentado).

Neste momento convém discutir a distinção entre aspecto gramatical e aspecto lexical, ou semântico, ou ainda Aktionsart.

A relação entre aspecto gramatical e aspecto lexical ou semântico é ainda debatida, pois depende da definição de gramática. O único consenso que parece haver é que as classes aspectuais parecem estar universalmente disponíveis (Bach, 2004) mas se apresentam de maneiras altamente diferenciadas nas várias línguas. Nem todas as línguas possuem morfologia verbal distinguindo perfectivo e imperfectivo, mas todas devem possuir algum meio de expressar essa distinção (Filip 1991).

Essa observação leva à possibilidade de que o aspecto gramatical seja uma categoria semântica oculta no nível sentencial em idiomas que carecem da categoria formal de aspecto (Kratzer 2004), o que estimula debates sobre a possibilidade de reduzirmos as categorias de aspecto lexical e a semântica do aspecto gramatical aos mesmos conceitos aspectualmente relevantes, analisados com as mesmas ferramentas e com a mesma 
representação semântica subjacente (Filip 1991, Swart 1998, Sasse 2002), o que poderia levar eventualmente a uma categoria unificada de aspecto, que em cada idioma pode ser gramaticalizada ou não, de uma certa maneira.

O termo 'aspecto lexical' ou 'Aktionsart', na literatura atual é usado essencialmente para qualquer distinção aspectual não expressa por flexão gramatical no sistema verbal de um idioma. Inclui tanto o aspecto expresso por itens lexicais distintos do idioma quanto a aspectualidade afetada pela definição e/ou número dos argumentos nominais de um verbo e sua interação com a semântica do verbo em si.

Segundo Filip (2001) (baseada em Bach (1981)), o aspecto lexical é uma categoria semântica relacionada às propriedades de eventos expressos por verbos. Tais propriedades estão relacionadas a algum limite ou fronteira na estrutura lexical de certas classes de verbos, bem como à sua ausência em outras classes.

O conceito interage e se relaciona com aspecto gramatical, tempo verbal, advérbios, sintaxe e semântica de quantificação e definição, com estrutura argumental, desempenhando um papel na interface entre semântica e sintaxe e no sequenciamento temporal do discurso (Filip 2001).

A distinção aspectual que mais comumente ocorre no nível lexical é a de telicidade (Filip 2001, Garey 1957).

Para Garey, verbos télicos expressam uma ação que persegue um alvo a ser completamente afetado pela ação descrita pelo verbo, ao passo que verbos atélicos expressam situações que se realizam assim que começam (Garey 1957 p. 106).

Testes comuns para determinar telicidade incluem acrescentar modificadores adverbiais temporais, como "dentro de uma hora" (só gramaticais com predicados télicos) e "por uma hora/no decorrer de uma hora" (só gramaticais com predicados atélicos). Vejamos (a) e (b) abaixo:

(a) João se recuperou em uma hora/ $(*)$ por uma hora > TÉLICO 
(b) João nadou (*) em uma hora/ por uma hora > ATÉLICO

A ação télica de "se recuperar" só pode se realizar no final de um período de tempo, expresso acima por "em uma hora", ao passo que mesmo no primeiro segundo na água a pessoa já pode ser descrita como alguém que está nadando, tenha essa ação se prolongado por uma hora ou não. Mas isso não significa que o verbo 'recuperar-se' deva ser classificado como lexicalmente télico, como se telicidade fosse uma propriedade sua como sua valência ou como o gênero é uma propriedade gramatical inerente de um nome.

Por exemplo, poderíamos dizer "João se recuperou por uma hora" no sentido de que por uma hora ele apresentou melhorias de saúde, que, contudo, cessaram e seu quadro começou a piorar ou estabilizar-se, sem que tenha atingido um estado de saúde pleno, embora nesse caso devamos dizer que João não se recuperou realmente, pois a ação de "recuperar-se" não foi concretizada, levada ao seu fim (telos).

Quantificadores vagos como "muito, bastante" ('ele nadou muito', 'ele dormiu muito', 'ele comeu bastante') também selecionam verbos atélicos, ao passo que advérbios mais exatos em quantidade como "três vezes" são típicos com verbos télicos ('ele caiu três vezes', 'ele se recuperou três vezes').

Isso parece confirmar a teoria de que os verbos télicos exigem argumentos pacientes contáveis. Mourelatos (1978) propõe ainda as categorias de "tipos" (sorts) e "princípios" (principles): "um universal de tipo (sortal universal) fornece um princípio para distinguir e contar os elementos individuais que ele coleta". Assim como "mesa" é um sortal (contável) e "água" não é (é incontável, ou massivo), o verbo "explodir" é um sortal, mas "dormir" não é, o que cria para os verbos uma distinção paralela à da contabilidade nominal.

Continuando com a mesma lógica, assim como nomes incontáveis como "água" passam a ser contáveis (em certos idiomas) diretamente em expressões como "três águas" (três copos de água ou três tipos de água), verbos tipicamente atélicos como "dormir" podem passar a ter uma interpretação télica ao serem modificados por adverbiais de contagem como "três vezes". 
Temos também o fenômeno chamado de "paradoxo do imperfectivo" (Dowty, 1977, 1979, p. 133 et seq.) ou o "enigma do partitivo" (Bach, 1986): uma sentença progressiva (em idiomas como o português e o inglês, que possuem formas verbais progressivas, ou 'contínuas' com auxiliar e gerúndio) com um predicado básico télico é verdadeira num dado momento mesmo se a sentença equivalente não progressiva for falsa e nunca puder ser verdadeira. Por exemplo, verbos télicos jamais permitem a conclusão de que "x fez" a partir de "x está fazendo", ao contrário de atélicos: De "Pedro está morrendo" não se conclui que ele morreu, mas "Pedro está dormindo" pode implicar que ele já dormiu.

Sendo assim, os diversos aspectos lexicais se distinguem por critérios semânticos. No caso da derivação de verbos a partir de outros verbos, o aspecto lexical pode ser expresso por certos morfemas, sendo nesse caso uma categoria derivacional. Como a linguística moderna tende a considerar a morfologia derivacional e a flexional como ocorrendo no mesmo nível sintático, esse tipo de derivação verbal deve ser considerado como parte da categoria de aspecto gramatical. Por exemplo, a famosa derivação de pares aspectuais nas línguas eslavas, em que um verbo básico imperfectivo se torna perfectivo pelo acréscimo de um prefixo (Russo chitat' imp. > prochitat perf. 'ler'), e um verbo básico perfectivo se torna imperfectivo por meio de um sufixo (dat' perf. > davat' imp. 'dar') deve ser considerada uma expressão do aspecto gramatical do idioma, e não do aspecto lexical.

Por exemplo, o termo aspecto lexical é usado para explicar a diferença entre sentenças como (c) e (d) abaixo:

(c) Na corrida o vencedor atravessou a linha de chegada em 1 hora

(d) Na corrida, os corredores atravessaram a linha de chegada por vários minutos.

O verbo "atravessar" é lexicalmente o mesmo em ambas as sentenças, igualmente conjugado no pretérito perfeito, e o aspecto se expressa aqui por meio das propriedades referenciais e quantificativas dos sintagmas argumentos do verbo.

Percebe-se que a telicidade depende dos outros elementos da sentença, notadamente do número e definição dos argumentos verbais e de certas expressões adverbiais. 
Desde Vendler (1957/1967) também se classificam os predicados verbais em quatro classes aspectuais:

estados - denotam eventos estáticos, durativos e atélicos (saber, amar, estar doente, estar na cidade, pesar $10 \mathrm{~kg}$, possuir um carro). Estados podem responder à pergunta: por quanto tempo...?

atividades - denotam processos, eventos dinâmicos durativos e atélicos (comprar, comer, aprender, tomar sorvete, desenhar círculos, dirigir um carro). Atividades respondem à pergunta: por quanto tempo...?

accomplishments - denotam uma mudança prolongada de estado, eventos dinâmicos, durativos e télicos (adoecer, convalescer, correr até a escola, comer um sorvete, desenhar um círculo, destruir um carro) e agentivos. Accomplishments respondem à pergunta: quanto tempo levou para...?

achievements - denotam uma mudança súbita de estado, eventos dinâmicos, pontuais e télicos (explodir, reconhecer, encontrar algo, vencer o jogo, chegar à escola) e não agentivos. Achievements respondem à pergunta: a qual momento...?

Os verbos dados como exemplos acima são apenas uma indicação de seu uso típico mais frequente, pois um verbo não pertence fixamente a uma classe aspectual.

Outra maneira de descrever as quatro classes de Vendler é a seguinte, retirada de Verkyul, 2002:

Estado: A amava alguém de T1 a T2, ou seja, em qualquer momento entre T1 e T2.

Atividade: A estava correndo no momento T, ou seja, esse instante T está em uma linha do tempo pela qual A estava correndo.

Accomplishment: A estava desenhando um círculo no momento $\mathrm{T}$, ou seja, $\mathrm{T}$ está na linha do tempo em que A desenhava aquele círculo.

Achievement: A venceu a corrida entre T1 e T2, ou seja, o instante em que A venceu a corrida fica entre $\mathrm{T} 1 \mathrm{e} \mathrm{T} 2$. 
A tabela 6 resume as classes acima como resultado primariamente de maior ou menor dinamicidade, e, secundariamente, da interação entre telicidade de duração, segundo Comrie (1976), que adiciona a categoria de 'semelfactivo' ou 'pontual' (em que inclui verbos como 'espirrar', 'piscar'):

\begin{tabular}{|c|c|c|c|c|}
\hline \multicolumn{2}{|c|}{$\begin{array}{c}\text { EVENTO } \\
\text { estado }\end{array}$} & \multicolumn{3}{|c|}{ +dinâmico } \\
evento \\
\end{tabular}

Tabela 6 - Classes aspectuais de Vendler + Comrie

O termo "classe aspectual" também é usado intercambiavelmente com Aktionsart para a classificação de meios derivacionais explícitos (afixos verbais, em sua maioria) que expressam vários aspectos de situações (p. ex. terminativo, resultativo, delimitativo, perdurativo, iterativo, semelfactivo, atenuativo, aumentativo), em contraste com a morfologia flexional usada para distinguir aspecto gramatical, mas isso varia de idioma para idioma. Como já vimos, o contraste entre perfectividade e imperfectividade nas línguas eslavas é feito por meio de afixos em grande parte imprevisíveis, que precisam ser indicados nos dicionários.

E notamos que a telicidade tende a aflorar a partir da conjunção de propriedades de vários sintagmas e considerações semânticas (baseadas em grande parte no nosso conhecimento de mundo extralinguístico), ao passo que a perfectividade é uma categoria que pode ser expressa simplesmente por meio de um único morfema ou flexão (tipicamente verbal). 
Talvez seja melhor, como Comrie (1976) sugere, falar apenas de aspecto, e deixar para cada idioma a questão de como esse aspecto será expresso, se por meios morfológicos gramaticais ou por meios sintáticos.

Tampouco devemos considerar que aspecto equivale a aspecto verbal, como se a categoria de aspecto, quando expressa morfologicamente, só fosse expressa pela morfologia do verbo. A telicidade, como aludido acima, tende a ser expressa pela interação de elementos do sintagma verbal com elementos do sintagma nominal, e existe também a categoria pouco explorada do aspecto estritamente nominal, i.e. substantivos que em si denotam ações perfectivas e imperfectivas, como p. ex. o servocroata 'stvaranje' ('criação', no sentido da ação de criar, genérica 'a criação do mundo') e 'stvorenje' (criação, um objeto que é resultado de uma ação criadora, como 'a criação do artista'), nesse caso derivadas do par aspectual stvariti (imp) / stvoriti (pf) 'criar', ou p. ex. o termo 'formatação' em português, no sentido imperfectivo de 'formatação de textos é um processo difícil' versus perfectivo 'a formatação do texto está ruim'.

\subsection{Aspecto, tempo e modo em Dâw}

Nessa seção será analisado, com base na discussão teórica sobre aspecto na seção anterior, o aspecto no idioma Dâw, especialmente os 15 morfemas postulados por Martins (2004) como marcadores de aspecto. Como se verificou no presente trabalho que muitos desses morfemas não expressam aspecto, o termo sugerido é 'morfemas funcionais verbais', ou 'operadores verbais' pois uns exprimem aspecto (e tempo), outros modo, outros expressam quantificação, ou performam a função de advérbios. 


\subsubsection{Introdução à língua Dâw}

Antes de entrar na discussão sobre o aspecto verbal em Dâw, gostaríamos de oferecer uma breve introdução ao idioma e à sua comunidade de falantes, de modo a melhor situar a discussão que concerne este trabalho.

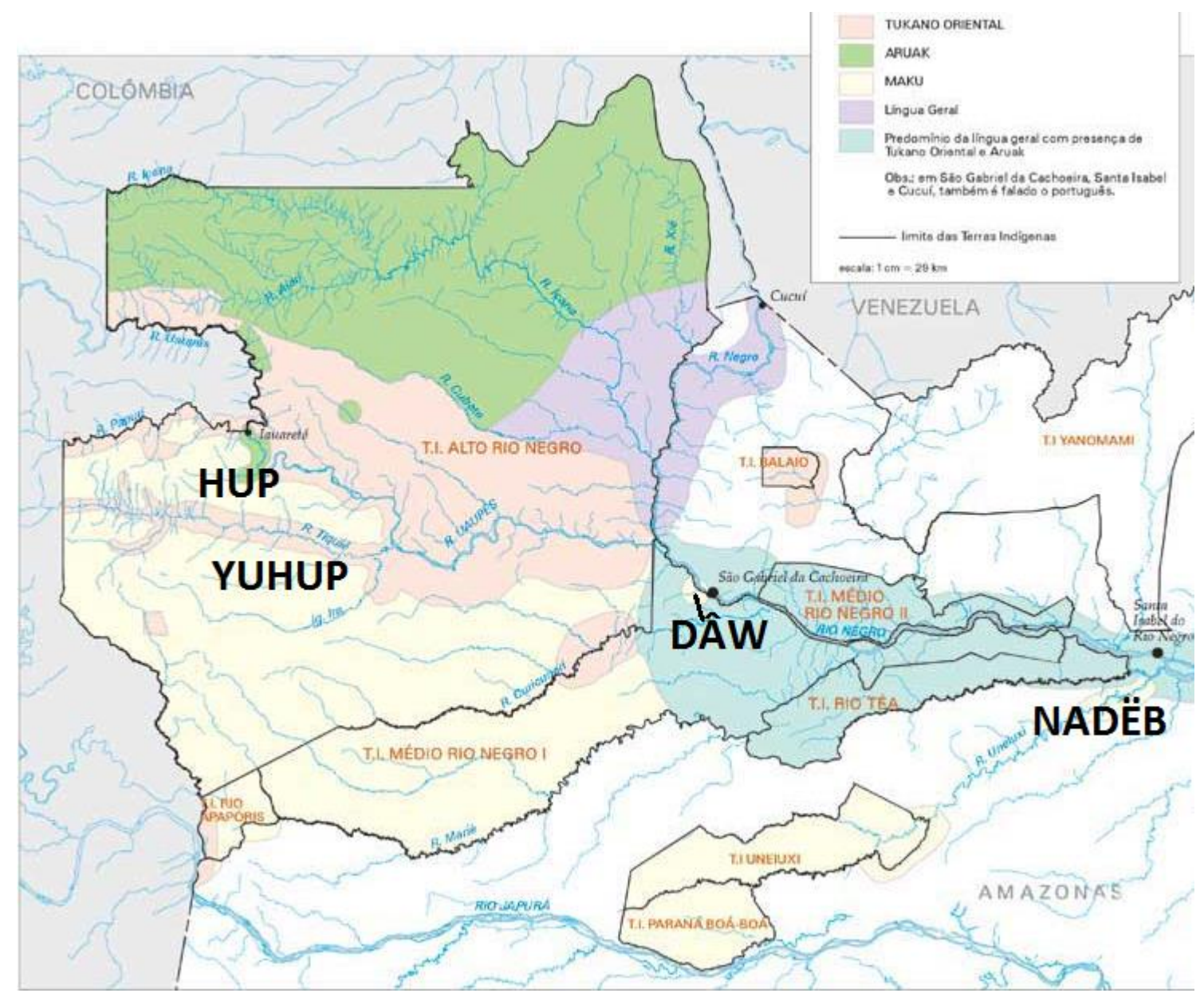

Figura 4 - Distribuição geográfica das línguas Nadahup

A língua Dâw pertence à família denominada Nadahup (ver fig. 5), termo formado a partir das sílabas iniciais de seus ramos integrantes: O Nadëb, o Hup, o Yuhup, e o Dâw ${ }^{4}$. Anteriormente ${ }^{5}$, a família era conhecida como Makú, termo de origem Aruak que significa "sem fala", atualmente preterido pelos linguistas devido à sua conotação pejorativa. Além do mais, o termo Maku também é encontrado na literatura

\footnotetext{
${ }^{4}$ Tanto o Hup quanto o Yuhup são representados pela última sílaba do nome novo da família - Nadahup.

${ }^{5}$ No livro The Amazonian Languages (2000), o nome da família ainda é dado como apenas Makú.
} 
denominando uma série de línguas e grupos amazônicos não relacionados com a fampilia Nadahup ${ }^{6}$, como Máku ou Makú, falada no rio Auari, em Roraima, Brasil; Mako ou Cofán-Makú, falada na área do lago Cuyabeno, na Colômbia e no Equador; e Makú,

Sá liba-Maco, ou Maco-Piaroa, um subgrupo da família Sáliba-Piaroa, na Venezuela (Martins \& Martins 1999).

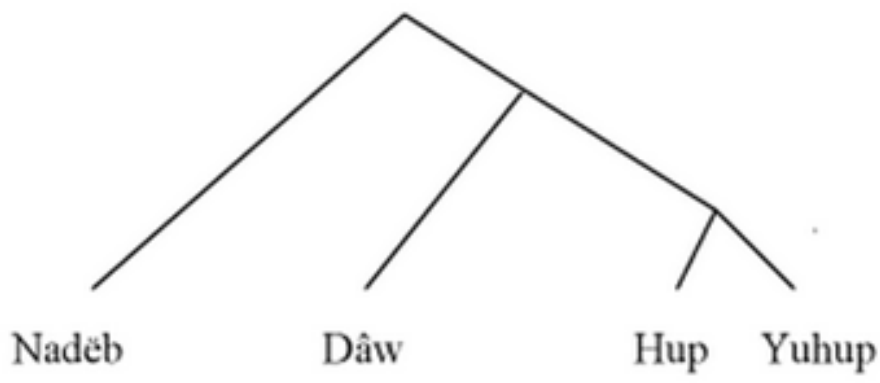

Figura. 5 - Subdivisão da família Nadahup (Epps, 2005, p. 3)

A população Dâw é formada por aproximadamente 120 pessoas que residem na região do Alto Rio Negro, no município de São Gabriel da Cachoeira, na comunidade conhecida como Waruá, no estado do Amazonas, Brasil. Os Dâw e as outras comunidades Nadahup convivem nessa região com falantes de idiomas de outras famílias, tais como os Aruak (Tariana) e os Tukano Orientais Oriental (Tukano ou Dahsea, Wanano, Desano, Tuyuca, Barasano, Piratapuya, entre outros), cujos idiomas, junto com o Nheengatu e o português, podem ter influenciado, em graus diferentes, a língua Dâw e suas irmãs, e vice-versa, no que pode ser descrito como área linguística ou Sprachbund ${ }^{7}$.

A principal fonte de informações sobre a língua Dâw é a gramática escrita por Silvana Martins, "Fonologia e Gramática da Língua Dâw", de 2004, única gramática completa do idioma publicada até hoje. Essa autora e seu marido Valteir Martins publicaram anteriormente algumas dissertações e teses sobre o idioma, como Análise da

\footnotetext{
${ }^{6}$ Até recentemente se especulava que os idiomas Kakua e Nukak, falados na Colômbia, pudessem ser membros da família Nadahup, embora altamente divergentes. Análises mais recentes, contudo, refutam essa inclusão (Epps \& Bolaños, 2009).

${ }^{7} \mathrm{O}$ termo Sprachbund (liga de idiomas, em alemão) foi uma tradução do termo russo языковой союз /jazykovoj sojuz/ pelo linguista Nokolai Trubetzkoy em 1923, mas o conceito é de autoria de Jernej Kopitar, que em 1830 descreveu o Albanês, o Búlgaro e o Romeno (o que chamamos de Sprachbund balcânico, o primeiro a ser identificado) como 'nur eine Sprachform...mit dreierlei Sprachmaterie' (apenas uma forma gramatical em três tipos de conteúdos lexicais).
} 
Morfossintaxe da Língua Dâw (1994), Análise Prosódica da Língua Dâw numa Perspectiva Não Linear (Valteir Martins, 1994), e Reconstrução do Proto-Maku Oriental (Valteir Martins, 2005). O livro The Amazonian Languages, editado por Aikhenvald e Dixon (2000) oferece um resumo do que se sabia sobre as línguas da família à época.

Mais recentemente surgiram algumas outras fontes de pesquisa a partir de dissertações de mestrado e teses de doutorado do grupo de estudo de Dâw na USP, como a dissertação de Mestrado de Jéssica Costa (2014) e a de Wallace Andrade (2014), baseadas em dados coletados em recentes pesquisas de campo sob a supervisão da professora Luciana Storto, em projeto de pesquisa envolvendo a professora Patient Epps, da Universidade do Texas, que escreveu uma gramática de Hup.

Com base nessas fontes, podemos descrever o idioma como de alinhamento nominativo-acusativo ${ }^{8}$, isolante, SVO (com instâncias de VSO em topicalização), com posposições (mas outros núcleos sintáticos predominantemente iniciais dentro dos sintagmas que projetam $^{9}$ ), léxico quase totalmente monossilábico, com marcação de caso apenas para objeto definido/ animado (marcação diferenciada de objeto, glosada aqui AFET 'afetado'), e com um baixo índice de ocorrências de afixos. Não há gêneros ou classes nominais, e quanto a número, a pluralidade no nome só é marcada em nomes animados, em circunstâncias excepcionais (por um morfema posposto, dâr), e nos pronomes.

Não há o contraste entre primeira pessoa do plural inclusiva e exclusiva. Não existe voz passiva. Há marcação de evidencialidade reportativa pela partícula mãr. Os interrogativos ('palavras WH') são normalmente frontalizados. Existem orações relativas, pospostas ao antecedente e com relativizador no final da oração, embora relativas adjetivas objetivas possam ocorrer sem conjunção alguma. Não há concordância. Apenas algumas posposições são selecionadas de acordo com a forma ou consistência do seu complemento.

\footnotetext{
${ }^{8}$ Como descrito em maior detalhe na seção 4.2.3, existe um morfema verbal quantificador que parece operar com uma orientação ergativa no idioma, mas não configura traço real de ergatividade.

${ }^{9}$ A existência de posposições no idioma geralmente sugere, na Linguística moderna, a predominância de núcleos finais no idioma, por isso o parêntese.
} 
Orações subordinadas são pospostas ao antecedente e são opcionalmente marcadas com um complementizador em seu final ('uy, pay).

Foneticamente o Dâw é uma língua tonal em nível lexical e de acento tonal previsível em níveis acima da palavra, de estrutura silábica predominantemente CVC e dotada de vogais nasais fonêmicas.

\subsubsection{O sistema verbal em Dâw}

É necessário um entendimento sobre o sistema verbal do idioma para podermos compreender o aspecto verbal em Dâw.

Segundo Martins (2004), o Dâw possui os seguintes tipos de verbos:

Verbos ativos: são verbos de ação e o sujeito é agente (ou causa). Essa classe é dividida em três categorias de acordo com o número de argumentos que o predicado verbal projeta.

Estes são divididos em: ativos intransitivos (projetam um argumento): verbos intransitivos possuem apenas um argumento sujeito, cujo papel temático é agente (exemplo: ' $z u b$, 'acordar'); ativos transitivos: de dois argumentos: sujeito, cujo papel temático é agente; e objeto, cujo papel temático é paciente/tema (exemplos: weed 'comer', yũt 'matar'); e bitransitivos: verbos com três argumentos: sujeito, objeto direto e indireto, com papéis temáticos de agente, paciente/tema e alvo (exemplos: nõo 'dar', buy 'jogar').

Verbos de processo: são verbos de mudança de estado e de eventos espontâneos e fenômenos da natureza, sem causa externa, de valência intransitiva e projetam um único 
argumento sujeito, agente ou paciente (exemplos: rõ 'queimar', bax 'aparecer', dok 'apagar', nâxdoj 'chover').

As duas categorias acima parecem abranger o que em muitas obras se denominam 'verbos dinâmicos'.

Verbos estativos: segundo Martins (2004), esses verbos possuem valência intransitiva e projetam um único argumento sujeito cujo papel temático é paciente/tema. Eles podem se subdividir em duas subclasses: equativos: possuem a função de uma cópula. Eles são divididos em duas subclasses: equativos existenciais: são verbos empregados para apresentar a existência de um ser (ou coisa). Exemplos: ñ̃ (estar, existir, haver), mẽr (não estar, não existir, não haver), rew (ter ou haver muitos) e equativos identificacionais: são verbos empregados para designar o estado de um ser (ou coisa). Exemplos: wztd 'era, passado', mãy 'não ser', etc.

Verbos descritivos: verbos estativos descritivos indicam conceitos que em outras línguas são expressos pela classe de adjetivos. De acordo com a autora, esses verbos podem também modificar nomes, exprimindo o estado, o atributo e a posição de um nome. Se subdividem ainda em:

a. Verbos atributivos: descrevem características inerentes de um ser ou objeto, como 'mẽn 'ser curto', ou bêt 'ser listrado'.

b. Verbos qualificativos: descrevem características transitórias ou comportamentais como dup 'azedo', 'enh 'feio', dâw tâaw 'bravo'.

c. Verbos posicionais: indicam a posição e o estado de um ser ou objeto, como yêt (estar no chão), peem (estar sentado).

O que Martins chama de verbos estativos parece corresponder ao que a literatura linguística chama de 'verbos de ligação, equacionais e existenciais', e os verbos que Martins designa 'descritivos' são geralmente denominados de 'verbos estativos' na maioria das obras. Nesta obra usaremos a termonologia da literatura geral, 'ativos' ou 'dinâmicos' e o termo ‘estativos' abrangerá os estativos e descritivos de Martins.

A tabela 7 abaixo, extraída de Martins 2004, resume a classificação da autora: 


\begin{tabular}{|c|c|c|c|}
\hline & intransitivos & transitivos & bitransitivos \\
\hline \multirow{7}{*}{$\begin{array}{l}\text { Classes verbais } \\
\text { propostas por } \\
\text { Martins (2004) }\end{array}$} & $\begin{array}{ll}\text { verbo } & \text { ativo } \\
\text { intransitivo } & \end{array}$ & verbo ativo transitivo & verbo ativo bitransitivo \\
\hline & verbo de processo & & \\
\hline & $\begin{array}{l}\text { verbo estativo } \\
\text { equativo } \\
\text { identificacional }\end{array}$ & & \\
\hline & $\begin{array}{l}\text { verbo estativo } \\
\text { equativo existencial }\end{array}$ & & \\
\hline & $\begin{array}{l}\text { verbo estativo } \\
\text { descritivo atributivo }\end{array}$ & & \\
\hline & $\begin{array}{l}\text { verbo estativo } \\
\text { descritivo } \\
\text { qualificativo }\end{array}$ & & \\
\hline & $\begin{array}{|ll|}\text { verbo } & \text { estativo } \\
\text { descritivo } & \\
\text { posicional } & \\
\end{array}$ & & \\
\hline
\end{tabular}

Tabela 7 - classificação dos verbos segundo Martins

Por meio de testes linguísticos variados, incluindo alternância de valência e julgamento de (a)gramaticalidade, a dissertação de Jéssica Costa (2014) mostra que é possível simplificar essa classificação e reagrupar esses verbos em três classes, de acordo com a valência do verbo:

1 - classe dos verbos intransitivos (verbos intransitivos de processo, estativos equativos e suas subclasses) e estativos descritivos (e suas subclasses);

2 - classe dos verbos transitivos

3 - classe dos verbos bitransitivos

Além disso, Costa propôs que alguns dos lexemas classificados como verbos descritivos por Martins na verdade são verdadeiros adjetivos, pois são usados como tais quando qualificam atributivamente um nome. 
No sistema verbal da língua, as categorias de tempo e aspecto são indicadas geralmente por palavras independentes (não afixais) em sua maioria gramaticalizadas a partir de verbos, possivelmente por meio da estrutura de construções verbais seriais, em que um verbo principal é auxiliado em seu significado e função por um verbo secundário. Além de 15 morfemas chamados de aspectuais por Martins (2004), existe um pequeno número de sufixos verbais não categorizados por Martins como aspectuais sumarizados abaixo. Os morfemas de tempo não são obrigatórios.

\begin{tabular}{|c|c|}
\hline negação & $-\tilde{e} r$ \\
\hline presente & zero \\
\hline passado $^{10}$ & $-{ }^{\prime} \hat{e} e^{\prime}$ \\
\hline futuro absoluto' & -'ey \\
\hline futuro imediato & -'̃ey \\
\hline imperativo & -'or \\
\hline imperativo negativo & -'érĩr \\
\hline
\end{tabular}

Tabela 8 - Afixos verbais em Dâw

Também existe um morfema solto, $n \tilde{a}$, posposto ao verbo, indicando futuro.

O sufixo de passado -êe' parece ser cognato com um sufixo Hup -e, que é considerado marcador de aspecto perfeito (Epps, 2005).

Nos testes dos trabalhos de campo realizados para esta pesquisa, selecionamos os verbos de acordo com uma versão modificada da categorização de Costa acima, considerando as seguintes classes de verbos:

1 - verbos ativos ou dinâmicos (todos os transitivos são desse tipo, e também os intransitivos 'de processo'). Para alguns morfemas funcionais, foi testado o contraste entre transitivos e intransitivos.

2 - verbos estativos (são os adjetivos do idioma) e alguns verbos de ligação como $n \tilde{\imath}$ (estar) e mẽr (não ser)

\footnotetext{
${ }^{10}$ Geralmente traduzido pelo pretérito imperfeito
} 
3 - verbos cognitivos, intransitivos significando pensamento, sensações, emoções, que muitas vezes se comportam de modo especial, similar aos estativos.

\subsubsection{Sistema aspectual em Dâw}

A tese de Martins (2004) postula a existência de 15 morfemas indicadores de aspecto na língua Dâw, sendo que 14 são palavras independentes e um é sufixal. A maioria desses morfemas é, ainda segundo Martins, derivada de verbos usados em construções seriais ou concatenativas, com algumas exceções, como se vê na Tabela 9 abaixo. Esses marcadores de aspecto aparecem sempre após o verbo (certos advérbios alojados no sintagma verbal e os marcadores de negação e imperativo podem ocorrer entre o verbo e os morfemas aspectuais).

\begin{tabular}{|c|c|c|c|}
\hline \multicolumn{2}{|c|}{ VERBOS (origem lexical) } & \multicolumn{2}{|c|}{ MARCADORES DE ASPECTO } \\
\hline$t a^{\prime}$ & distanciar & $t a^{\prime}$ & imperfectivo \\
\hline$y \tilde{u} t$ & matar & $y \tilde{u} t$ & perfectivo 1 \\
\hline$r \tilde{u}^{\prime}$ & acabar & $r \tilde{u}^{\prime}$ & perfectivo 2 \\
\hline wutd & possibilidade de ser & wutd & frustrâneo \\
\hline rãm & ir & $-\tilde{a} m$ & télico \\
\hline$x \hat{a} d$ & passar, desocar & $x \hat{a} d$ & durativo \\
\hline$d \hat{a} r$ & passar subitamente & $d \hat{a} r$ & pontual \\
\hline bey & repetir & beey & iterativo \\
\hline tâg & conhecer & tâag & habitual 1 \\
\hline 'weer & - & 'weer & habitual 2 \\
\hline yow & ser reto/ atalhar & yow & progressivo 1 \\
\hline$k a^{\prime}$ & - & $k a^{\prime}$ & progressivo 2 \\
\hline te & (filho) & tee & progressivo 3 \\
\hline yed & - & yed & intensivo 1 \\
\hline 'uy & - & 'uy & intensivo 2 \\
\hline
\end{tabular}

Tabela 9 - Marcadores de aspecto e cognatos em Dâw (Martins, 2004: 287) 
A análise do sistema aspectual do Dâw apresentada em Martins (2004) baseia-se na matriz de aspectos de autores como Bybee (1985), Talmy (1985), Comrie (1976b) e Frawley (1992), que categorizam aspectos em abertos, fechados e fases:

\section{aberto: imperfectivo > durativo / habitual > progressivo > iterativo}

\section{fechado: perfectivo > pontual / télico > não iterativo}

fases: intensivo/ inceptivo > prospectivo > terminativo / retrospectivo

$\mathrm{Na}$ lista acima os aspectos estão 'hierarquizados de acordo com a predominância lógica e distribucional em que se encontram nas línguas' (Martins, 2004, p. 286).

Segundo a autora, aplicando-se essa matriz ao Dâw, seus quinze morfemas que denomina de 'aspectos' se distribuem da seguinte maneira:

a. abertos: imperfectivo $t a^{\prime}>$ frustrâneo $w u t d>$ durativo $x a ̂ d>$ habitual 1 tâg > habitual 'weer > progressivo 1 yow > progressivo $2 \mathrm{ka}$ '> progressivo 3 te > iterativo beey

\section{b. fechados: perfectivo 1 yũt; perfectivo 2 rü'> télico -ãm > pontual dâr.}

\section{c. fases: intensivo 1 yed; intensivo 2 ' $u y$}

Na tabela 10 abaixo apresentamos uma comparação entre a descrição de Martins (2004) e a análise dos dados mais atuais das pesquisas de campo de 2014/205, onde preliminarmente confirmamos, rejeitamos ou modificamos a descrição de Martins com base nas novas levas de dados, adicionalmente informando frequência relativa dos morfemas nas amostras e dando alguns dados adicionais. As percentagens são aproximadas. 


\begin{tabular}{|c|c|c|}
\hline & MARTINS & DADOS ATUAIS \\
\hline$t a^{\prime}$ & imperfectivo & em desuso \\
\hline$y \tilde{u} t$ & perfectivo 1 & principal marcador de perfectividade \\
\hline$r \tilde{u}^{\prime}$ & perfectivo 2 & $\begin{array}{l}\text { quantificador nominal universal, sem conotação } \\
\text { aspectual }\end{array}$ \\
\hline wutd & frustrâneo & modal frustrativo, frequente \\
\hline$-\tilde{a} m$ & télico & aspecto ingressivo \\
\hline$x \hat{a} d$ & durativo & uso condicionado por vários fatores \\
\hline dâr & pontual & uso condicionado por vários fatores \\
\hline beey & iterativo & indica repetição, significa 'de novo' \\
\hline tâg & habitual 1 & $\begin{array}{l}\text { morfema de aspecto habitual por experiência } \\
\text { adquirida, presente e passado apenas }\end{array}$ \\
\hline 'weer & habitual 2 & algo equivalente a 'sempre' ou 'todo tempo' \\
\hline yow & progressivo 1 & $\begin{array}{l}\text { ação antes do esperado ('já') ou aspecto } \\
\text { perfeito (ação competada recentemente ainda } \\
\text { não revertida por ação posterior). }\end{array}$ \\
\hline$k a^{\prime}$ & progressivo 2 & $\begin{array}{l}\text { em desuso como marcador aspectual, significa } \\
\text { 'deitado na rede' }\end{array}$ \\
\hline te & progressivo 3 & $\begin{array}{l}\text { ação mais prolongada que o esperado, } \\
\text { geralmente satisfatoriamente traduzido como } \\
\text { 'ainda' }\end{array}$ \\
\hline yed & intensivo 1 & não aspectual, apenas advérbio de intensidade \\
\hline 'uy & intensivo 2 & não aspectual, apenas advérbio de intensidade \\
\hline
\end{tabular}

Tabela 10 - Dados atualizados sobre os 15 morfemas funcionais analisados

Na seção a seguir, cada morfema é analisado em sua sub-seção própria.

Cabem agora algumas considerações sobre quais teorias usamos para testar a função dos morfemas.

A primeira hipótese que levantamos para testar a função dos morfemas foi verificar quais alterações de aspecto (ou outra categoria) ocorrem quando um determinado morfema ocorre com verbos de diversos tipos. 
Esse raciocínio se deu com base em informações de outros idiomas isolantes dotados de morfemas aspectuais soltos, como o chinês, o tailandês e o vietnamita, tipologicamente similares ao Dâw por serem isolantes, terem pouca ou nenhuma morfologia verbal e por expressarem aspecto por meio de palavras soltas.

Por exemplo, no chinês, o marcador de perfectividade le com verbos de ação geralmente denota uma ação concluída confinada ao passado (em relação ao tempo de referência), portanto wǒ chī le [1sg comer PERF] 'eu comi' ou 'terei comido' ou 'tinha comido (variando o tempo de referência entre presente, passado e futuro). Contudo, com verbos estativos (os equivalentes dos adjetivos), sua função se altera, geralmente denotando que o estado indicado pelo verbo estativo se encontra válido no presente (do tempo de referência) e é resultado de uma transformação anterior:

\section{(d) wǒ gāo le}

1sg ser.alto PERF

'eu estou alto, eu fiquei alto, cresci'

Isso, em contraste com:

(e) wǒ gāo

1 sg ser.alto

eu sou alto

Sem o marcador de aspecto, a sentença meramente significa 'eu sou alto'. Fenômeno similar ocorre também em outras línguas isolantes com marcação de aspecto por partículas independentes, como no tailandês, com seu marcador de perfectivo pós-verbal leew, e no vietnamita com o marcador pré-verbal đã (ver seção 4.3).

Especulamos, portanto, se o mesmo se daria em Dâw. Assim, fizemos questão de testar todos os morfemas pelo menos contrastando entre as categorias de verbo ativo e verbo estativo, para verificarmos que alterações de significado ocorreriam, ou mesmo se seriam gramaticais. Verbos cognitivos (que não são uma categoria formal reconhecida por Martins nem Costa, mas presente em Dâw como qualquer idioma, e analisada aqui 
em separado, pois Comrie já notara, como descrito acima, a interação peculiar entre verbos cognitivos / sensoriais e aspecto) também foram testados, com base no fato de que em chinês verbos psicológicos e cognitivos quando ocorrem com le possuem também uma leitura perfectiva, com sentido de atualização: wǒ xǐhuan (eu gosto) > wǒ xǐhuan le (agora eu gosto, estou gostando, passei a gostar, mas antes não gostava). Foi verificado que a classe de verbo (especialmente as classes ativo, estativo e cognitivo) altera a função dos morfemas, de modo similar ao que ocorre no chinês e como observado por Comrie em outros idiomas.

Os morfemas verbais funcionais analisados nesta obra, nos casos em que possuem cognatos verbais no idioma, parecem ter se gramaticalizado (ou ainda estar se gramaticalizando) a partir de construções concatenativas, como 'acabei de fazer' (aspecto 'recente') ou 'terminei de comer' (aspecto terminativo).

Outras considerações usadas para o estudo estão explicadas nas seções específicas de cada morfema funcional.

\subsubsection{Aspecto na família Nadahup e no Sprachbund do Alto Rio Negro}

Adicionalmente pesquisamos o aspecto verbal em idiomas da família Nadahup e em outros idiomas que formam a área linguística (possível Sprachbund) do Alto Rio Negro, em especial Tukano e Nheengatu ${ }^{11}$, que são os idiomas indígenas dominantes na região, com a intenção de compreender melhor esse grupo de morfemas no próprio Dâw, bem como derivar insights sobre a sua evolução nos idiomas da família linguística e no Sprachbund em questão.

\footnotetext{
${ }^{11}$ O Nheengatu ou Língua Geral, formada com base no antigo Tupinambá da costa de São Paulo, foi levado à região em tempos coloniais pelos bandeirantes e, devido ao isolamento da área, sobreviveu apenas lá até atualmente, tendo sido idioma dominante local até recentemente. O Tucano (Dahsea), idioma da família Tucano,veio a superar o Nheengatu como idioma indígena predominante da região devido ao seu uso pela Missão Salesiana católica iniciada na região em 1914, bem como posteriores esforços missionários católicos.
} 
Foi possível determinar que existem várias similaridades e paralelos entre os sistemas de marcação morfológica modo-aspectuais entre vários idiomas da região, entre as diversas famílias linguísticas, o que certamente perfigura característica difundida arealmente. O idioma Tukano, dominante na região atualmente, por exemplo, também possui uma série de morfemas pós-verbais com funções modais, aspectuais e outras, com grande paralelismo com o sistema encontrado nas línguas Nadahup. A idioma Tariana, língua Aruak fortemente influenciada pelo Tukano, também possui sistema similar (Aikhenvald, 2003).

Nas tabelas (11) a (13) abaixo, apresentamos uma listagem dos marcadores de aspecto em Tariana (Aikhenvald, 2006) e Tukano (West, 1980) e Hup (Epps, 2006).

\begin{tabular}{|c|c|}
\hline \multicolumn{2}{|l|}{ Tariana } \\
\hline -sita & perfectivo \\
\hline -niki & completivo \\
\hline -maña & semi-perfectivo (quase, prestes a) \\
\hline -ina & pontual (ação breve) \\
\hline -hyuna & habitual impessoal \\
\hline -kape & habitual geral \\
\hline -nipe & habitual repetitivo \\
\hline -pita, -ta & repetitivo \\
\hline- nhi & anterior \\
\hline -daka & progressivo \\
\hline -sida & progressivo próximo \\
\hline
\end{tabular}

Tabela 11 - Marcadores de aspecto em Tariana

\begin{tabular}{|c|c|}
\hline \multicolumn{2}{|c|}{ Tukano } \\
\hline -kã & enfático \\
\hline -toha & completivo \\
\hline$-k \tilde{u}$ & habitual passado \\
\hline$-\mathbf{m i}$ & frustrativo \\
\hline$-\mathbf{S a}$ & indefinido \\
\hline- no' & troca de enfoque \\
\hline -tamó & com, reciprocamente \\
\hline -bosá & em favor de, para \\
\hline$-n \tilde{a} '$ & tentar, ensaiar \\
\hline
\end{tabular}




\begin{tabular}{|l|l|}
\hline yu'rua & superiormente \\
\hline -sté & dispersar \\
\hline -yu & fazer antes do tempo \\
\hline -poá & estar acostumado a \\
\hline -marĩá & surpreendentemente \\
\hline nukãá & começar \\
\hline nukũú & parar \\
\hline pe'ó & terminar, acabar \\
\hline pe'tí & terminar \\
\hline
\end{tabular}

Tabela 12 - Marcadores de aspecto e outros operadores verbais em Tukano

\begin{tabular}{|c|c|c|c|}
\hline \multicolumn{4}{|l|}{ Hup } \\
\hline & semântica & forma(s) & $\begin{array}{l}\text { ocorrência com outras classes de } \\
\text { palavras }\end{array}$ \\
\hline dinâmico & $\begin{array}{l}\text { evento em progresso (em relação ao momento da } \\
\text { fala ou ao contexto da expressão) }\end{array}$ & $-V y^{12}$ & $\begin{array}{l}\text { nomes, etc. em certos contextos que } \\
\text { combinam cláusulas }\end{array}$ \\
\hline incoativo & começo de evento ou entrada em um estado & $-a y$ & nomes, foco incoativo \\
\hline perfectivo & evento visto em relação ao seu ponto final & $-' e^{\prime}-$ & nominais predicados \\
\hline completivo & evento completado antes do ato da fala & -cyp- & \\
\hline télico & $\begin{array}{l}\text { entidade (S/O) está completamente envolvida ou } \\
\text { afetada; fazer completamente }\end{array}$ & $-y \dot{t}-$ & $\begin{array}{l}\text { como enclítico em substantivos, ênfase } \\
\text { contrastiva. Como enclítico em adjetivos, } \\
\text { verbos, cláusulas inteiras; adverbializador }\end{array}$ \\
\hline ventivo & $\begin{array}{l}\text { movimento entre o local atual de participação e o } \\
\text { local onde o evento ocorre }\end{array}$ & -'ai- & \\
\hline habitual & evento costumeiro, recorrente (sem ponto final) & $\begin{array}{l}-b \dot{t g}- \\
-b \dot{i}-\end{array}$ & \\
\hline \multirow[t]{3}{*}{ iterativo } & $\begin{array}{l}\text { 'repetidas vezes', também durativo 'por muito } \\
\text { tempo' (com ponto final) }\end{array}$ & pid & \\
\hline & $\begin{array}{l}\text { repetição única de uma ação ou algum aspecto de } \\
\text { um estado resultante }\end{array}$ & $b^{\prime} a y$ & nomes, marcador de mudança de tópico \\
\hline & $\begin{array}{l}\text { o evento ou estado tem diversas ocorrências } \\
\text { intrínsecas }\end{array}$ & (reduplicação) & $\begin{array}{l}\text { nomes (uso similar, apenas em formas } \\
\text { lexicais improdutivas) }\end{array}$ \\
\hline \multirow[t]{2}{*}{$\begin{array}{l}\text { 'diminutivos' } \\
\text { verbais }\end{array}$} & fazer a atividade um pouquinho & $\begin{array}{l}\text {-kode (do } \\
\text { tukano) }\end{array}$ & \\
\hline & & $d \dot{t}^{\prime}$ & \\
\hline $\begin{array}{lr}\text { marcador } & \mathrm{de} \\
\text { 'evento } & \mathrm{em} \\
\text { progresso' } & \end{array}$ & atividade ou evento ainda em progresso & toe & certos predicados nominais \\
\hline
\end{tabular}

${ }^{12}$ Como de praxe, o V maiúsculo aqui indica vogal repetida da palavra à qual o sufixo é adicionado. 
Dos dados acima podemos inferir que alguns morfemas do Hup têm relação semântica e etimológica clara com os do Dâw: o iterativo 2 do Hup, $b^{\prime} a j^{13}$, é similar em forma e função com o iterativo beey do Dâw, e o progressivo tae do Hup é similar em forma e função ao progressivo 3 te do Dâw. Em Hup o verbo ham (ir), cognato e sinônimo de rãm em Dâw, pode, como em Dâw, servir para formar verbos ingressivos a partir de raízes nominais e verbais.

O sufixo glosado como perfectivo na tabela do Hup, (' $e$ '), é, com toda probabilidade, cognato com o marcador de passado Dâw (-êe'). O -Vy 'dinâmico' do Hup pode ser cognato com o 'uy 'intensivo 2' do Dâw.

O Hup tem um verbo equivalente ao rü' do Dâw, hũ', igualmente com o significado de 'terminar, acabar', e que é muito usado naquele idioma em conjunção com sufixos aspectuais como completivo -cip- e télico -yit. Vemos, assim, que a linha entre morfemas funcionais aspectuais e construções verbais concatenativas é difícil de traçar, pois os primeiros tendem a ser gramaticalizações destes últimos.

Em Hup, o aspecto chamado de télico em orações intransitivas indica que o sujeito foi ‘totalmente afetado', segundo Epps:

\section{(a) ‘ãh 'ëgna'.yi'.iy}

1sg tomar-porre-TEL-DINÂMICO

'bebi até cair'

Em orações transitivas o marcador de 'télico' indica que o objeto do verbo foi totalmente afetado pela ação, mesmo quando esse objeto é omitido como em (b), fenômeno idêntico ao verificado em Dâw (ver seção 4.2.3 rũ'):

\section{(b) tih 'ëg.yi’.iy}

\footnotetext{
${ }^{13}$ Observe que os termos em Hup na fonte estavam na transcrição fonética baseada no Alfabeto Fonético Internacional, aqui foram adaptados à ortografia Hup usada correntemente.
} 
3sg beber-TEL-DIN

'ele bebeu tudo'

(c) huptok ‘ãh g'op.yi'.iy

caxiri $1 \mathrm{sg}$ servir-TEL-DIN

'eu servi todo o caxiri' (o caxiri acabou)

Em Tukano, idioma mais difundido e dominante da área, dois dos 'auxiliares' (denominação de Birdie West, 1980) são os verbos pe'ti e pe'o, ambos significando 'acabar, terminar' (exatamente como rũ' em Dâw e hũ' em Hup) mas como auxiliares verbais implicando uma quantificação universal do argumento mais próximo do verbo (sujeito do intransitivo e objeto direto do transitivo):

(d) ba'a.pé'o.kã'.mi ${ }^{14}$

comer.completar.ENFÁTICO.3sgmasc

ele comeu tudo

(e) ba'ápe’tiama

comer.completar.PASSADOREMOTO.3pl

todos comeram

(f) wa'á.pe'ti.a.ma

ir.terminar.PASSADOREMOTO. $3 \mathrm{pl}$

eles todos foram

Fica claro que no Dâw, no Hup e no Tukano, e talvez em outros idiomas da região, se desenvolveu um morfema verbal indicador de aspecto terminativo misturado com função de quantificador dos argumentos nominais. Martins chama essa função de aspecto perfectivo 2, e Epps a rotula de télica. Ver a seção sobre o marcador rũ' abaixo para mais detalhes, bem como 4.3 onde um fenômeno similar é analisado em Cantonês.

\footnotetext{
${ }^{14}$ o verbo pe'o só ocorre com verbos transitivos, mas pe'ti ocorre com transitivos e intransitivos.
} 
O iterativo 1 do Hup pid deve ser relacionado a pud em Dâw, termo que indica intensidade, traduzido como 'muito'. O Hup também tem um marcador de modo frustrativo, yẽh. Seria interessante aprofundar a comparação dos sistemas dos dois idiomas para tirarmos insights sobre a marcação de aspecto na família.

No Tukano, os adjetivos seguidos pelo verbo wa'a 'ir' passam a indicar ingressivo, de transformação para o estado descrito pelo adjetivo, como vemos de (g) a (j) abaixo, extraídos de West (1980), em paralelo ao uso idêntico do verbo rãm 'ir' dem Dâw:

(g) butía wa'a-pu

maduro ir-PASS

está maduro

(h) asía wa'a-'a

quente IR-PRES

já está quente

(i) yusta wa'aparã

frio ir-PASS3pl

eles se esfriaram

(j) tutuá wa'ami

forte ir-PRES.3masc.sg

ele ficou forte

Quanto ao o Yuhup, que é geneticamente mais próximo do Hup que o Dâw, não foi possível detectar na gramática existente desse idioma (Bozzi 2002) uma série equivalente de morfemas 'aspectuais'. O Yuhup tem, segundo Bozzi, apenas três marcadores de aspecto verbal, também pospostos ao verbo, bè (repetitivo), dùbm (permansivo, algo como 'ainda') e wè ('proximidade prospectiva ou retrospectiva do limite inicial da situação', nas palavras de Bozzi), bem como um supramorfema tonal 'concomitante' (algo como tempo presente) e outro imperativo. 
Assim, o sistema do Yuhup, até onde pudemos averiguar, não tem parentesco visível com o que se observa em Dâw e Hup, embora especulemos que construções verbais seriais ou concatenativas em Yuhup possam exibir características aspectuais e modais ainda não exploradas na literatura, de modo menos gramaticalizado que em Dâw e Yuhup, mas que tenha paralelismos com os sistemas destes idiomas. Por exemplo, o verbo habm ('ir', cognato de rãm em Dâw e ham em Hup) é descrito como indicando 'aspecto indeterminado' em Bozzi. O Yuhup também tem um morfema hũ $i$, provável cognato do Dâw rũ ' e do Hup hũ e também significando 'terminar', mas sem a função quantificadora que possui no Dâw.

Não existe gramática completa de Nadëb. Na literatura acessível, não foi possível pesquisar o sistema aspectual desse idioma.

No Nheengatu, da família Tupi, existe um sistema de clíticos e partículas aspectuais um tanto menos extenso que no Dâw, com os morfemas clíticos wã (perfectivo) e re (imperfectivo), e o verbo auxiliar $i k u$ (progressivo, gramaticalizado a partir do verbo 'estar').

Como no Dâw, no Hup e no Tukano, o verbo su 'ir' do Nheengatu também é usado como auxiliar 'ingressivo' ou 'incoativo'. Em (g) abaixo, retirada da gramática de Aline da Cruz (2004), vemos como em Nheengatu o aspecto perfectivo associado a um verbo não ativo tende a exprimir situação atual resultante de uma transformação no passado, como observado no Dâw e mesmo em idiomas do leste asiático:

(g) ixe a-iku-wã ike (Da Cruz, 2004, p. 475)

$1 \mathrm{sg} 1 \mathrm{sg}$-estar-PERF aqui

eu já estou aqui

E, também como em Dâw, o marcador de perfectividade -wã quando usado em verbos estativos denota estado atual atingido, no Nheengatu:

(h) penhe pe-kuere=wã (Da Cruz, 2004, p. 142)

2PL 2ple-ser.cansado=PFT

vocês já estão cansados. 
Na seção 4.3 do capítulo seguinte são apresentados exemplos paralelos em idiomas do leste Asiático, mostrando um impressionante paralelismo com os idiomas do Alto Rio Negro, o que sugere que vários dos fenômenos analisados acima são frutos de alguma propriedade da Gramática Universal, que aflora comumente em idiomas isolantes com partículas aspectuais livres no mundo inteiro. 


\section{CAPÍTULO 4. Análise dos morfemas}

\subsection{Coleta de dados}

Os três primeiros trabalhos de campo, realizados em fevereiro e julho de 2013 e janeiro e fevereiro de 2014 pela Professora Luciana Storto com os alunos de mestrado Jéssica Costa e Wallace Andrade, junto aos membros da etnia Dâw em São Gabriel da Cachoeira, noroeste do estado do Amazonas, coletaram dados para os trabalhos de mestrado desses alunos.

No que diz respeito aos dados coletados para o presente projeto de pesquisa nestes três trabalhos de campo, cabe informar que a Professora Luciana Storto coletou, em fevereiro de 2013, alguns morfemas de aspecto com verbos de classes diferentes, e que, em julho de 2013 aplicou um questionário preparado por nós para a pesquisa de aspecto verbal pertinente a este trabalho, em que foram elicitados todos os morfemas de aspecto com verbos de diferentes categorias, segundo a categorização de Costa (2014). No terceiro trabalho de campo, em janeiro de 2014, a Professora Storto elicitou as sentenças do capítulo de Martins sobre aspecto em todos os tempos verbais.

No quarto e último trabalho de campo, de julho de 2015, que contou com a minha presença, foi possível elicitar uma grande, embora ainda insuficiente, quantidade de material sobre o tema do presente trabalho, e será principalmente com essa base de dados que ocorrerá a análise do aspecto verbal em Dâw nas seções a seguir.

O trabalho de campo de julho de 2015 coletou mais de 600 sentenças completas em Dâw elaboradas por este autor especificamente para testar uma série que hipóteses e resolver as várias questões e dúvidas levantadas sobre os quinze morfemas considerados como aspectuais por Martins e outras questões sobre o aspecto verbal em Dâw. 
Em São Gabriel da Cachoeira, os falantes foram trazidos ao hotel onde nos hospedamos eu, a professora Storto e o outro aluno de mestrado Lucas Cavalini Barboza (cujo projeto analisaria as consoantes glotalizadas do Dâw), por seis dias, entre o domingo dia 5 de julho e a sexta-feira dia 10 de julho de 2015, no período da manhã e da tarde, exceto no domingo, em que tivemos apenas a tarde para trabalhar. Os consultores vinham da comunidade indígena, que fica apenas a alguns minutos da cidade, atravessando o Rio Negro de barco.

Para os testes de aspecto, oito falantes nativos do idioma foram consultados: Mateus, Jonas, Sília, Ester, Deolinda, Valteirzinho, Tatiane, Valdemar. E também houve, à noite, a convite da chefe indígena Dna. Auxiliadora, uma série de consultas que desenvolvi sobre outras questões do idioma, complementares a este trabalho e também relativas à obra descritiva de gramática e vocabulário gerais do idioma que compilei desde antes do meu ingresso ao Programa de Mestrado, como pesquisa pessoal auxiliar que considerei essencial para a compreensão do tema específico 'Aspecto Verbal', devido à interligação desse tema com várias outras áreas da gramática do idioma.

Houve um interesse bastante intenso e claramente expresso por parte dos falantes nativos, especialmente da Dna. Auxiliadora, a líder política da comunidade naquele momento, pelo pequeno compêndio de vocabulário temático e resumo gramatical que compilei do idioma Dâw, o que aponta para uma carência de materiais simples e didáticos do idioma entre os falantes, que em alguns casos já começaram a se esquecer do idioma e substituir muitas palavras nativas por termos em português. Os falantes se divertiram e se interessaram bastante quando eu os questionei sobre termos para partes do corpo, animais, frutas, verbos gerais e outros termos, pois em alguns casos discordavam entre si e em muitos casos observavam como já estavam se esquecendo de certos vocábulos, e como havia divergência entre falantes. Em todos os casos, comentaram como seria importante a disponibilização de um material de consulto deste tipo (similar aos 'phrasebooks' de viagem) para que eles mesmos se recordassem de seu léxico e também para eventual ensino a outros visitantes e pesquisadores. 


\subsection{Descrição individual dos 15 morfemas de aspecto em Dâw}

Segue uma descrição individual sobre cada morfema objeto da pesquisa, com atualizações baseadas nos novos dados. Os morfemas aparecem na ordem apresentada em Martins (2004), e em cada morfema foram adicionados os exemplos das sentenças elicitadas nos trabalhos de campo em que o morfema relevante aparece. Também foi consultada, como material adicional de pesquisa, a coletânea de Narrativas Dâw, coletada em trabalhos de campo anteriores, e transcrita e traduzida sem glosa, mas que serve de amostra para a produção espontânea do idioma, em contraste com elicitações, que podem ser contaminadas por traduções e outros problemas.

Nossa hipótese original, oferecida como reanálise dos dados nesta seção, é que alguns morfemas descritos como aspecto por Martins (2004) são alguns apenas de aspecto, tempo e modo e outros de nenhuma dessas categorias.

\subsubsection{Imperfectivo ta $^{\prime}$ (em desuso)}

Segundo Martins, deriva do verbo homônimo 'distanciar, estar distante', ou em certos contextos 'ir um para cá outro para lá; distribuir', de onde também derivam palavras homônimas de outras categorias significando 'finado' (lit. 'aquele que ficou distante') e o pronome demonstrativo 'aquele lá' etc.

Ainda segundo a autora, quando este marcador de aspecto é usado no tempo futuro, transmite a ideia de 'tentativa de completar um evento como incerto'; no passado, indica algo similar a 'quase' (e nesse uso parece ter uma função de modo frustrativo - ver 
aspecto 'frustrâneo' abaixo). Martins adiciona que eventos no tempo passado marcados com $t a$ ' são 'entendidos como já cessados, mas sem estarem completos'.

(1)

$\begin{array}{llll}\text { me wây' ta' } \quad \text { mẽnh } & \text { te } \text { yar } \\ \text { 1PL.H ver estar distante } & \text { 1SG.POS } & \text { filho buscar } \\ \text { vamos lá longe para buscar meu filho } & \end{array}$

(2)

$\begin{array}{llrrr}\text { tum 'yãmxu' } & \text { yũt } \quad \text { yed } & \text { ta' } & \text { munh } \\ \text { duas } & \text { onça } & \text { matar INTS1 } & \text { IMP } & \text { 1SG.OBL } \\ \text { duas onças quase me mataram. }\end{array}$

(3)

'ãr kât dó' ta' be wâ' wut
1SG estar em pé Mov IMP pau em cima bem
eu vou tentar ficar em pé em cima daquele pau.

Contudo, segundo os dados das pesquisas de campo, esse morfema parece não estar mais em uso corrente no idioma.

E quanto aos dados de Martins, é questionável a qualidade de imperfectivo do morfema tá'. A tradução da maioria dos exemplos com $t a^{\prime}$ aparece com verbos no pretérito perfeito em português, seguido de advérbios que complementam o significado, geralmente indicando frustração na realização do evento. Talvez antigamente, quando ainda em uso, esse morfema tenha sido mais um indicador de modo frustativo ou de aspecto prospectivo combinado com modo irrealis (em que o tempo de referência é anterior ao tempo da situação - ela ainda ia almoçar quando eu cheguei), pois o modo frustativo não é compatível somente com imperfectividade.

\subsubsection{Perfectivo 1 yũt}


Segundo Martins, codifica eventos completos. Derivado do verbo homófono que significa 'matar, extinguir, terminar', e por extensão semântica passou a marcar o aspecto perfectivo.

(1) tir yũt yũt xet-ũũj'

3SG matar PERF1 jacaré-AFET

ele matou o jacaré

Na análise dos dados de 2014 e 2015 foi confirmada a utilização deste marcador de aspecto para indicar perfectividade, bem como seu frequente uso no idioma.

(2) 'ãr weed yũt yoon

1sg comer PERF1 tamanduá

eu já comi tamanduá

(3) 'ãr weed yũt

1sg comer PERF1

eu já comi

Coocorre frequentemente com o morfema -ãm (Martins o chama de 'télico', reanalisado neste trabalho como ingressivo, ver seção -ãm abaixo), que é sufixado a yũt:

(4) 'ãr weed yũt-ãm dep

1sg comer PERF1-TEL carne

eu já comi carne

A partir de (5) abaixo, listamos e analisamos as ocorrências de yũt no trabalho de campo de julho de 2015.

(5) bertâg kasãm yũt

árvore morrer PERF

a árvore já morreu 
Em (5) ocorre com verbo ativo 'morrer'.

(6) tir câk yũt bigid

3sg pular PERF de-repente

ele pulou de repente

Em (6) compatível com verbo ativo com advérbio indicando ação pontual súbita.

(7) dâwtee kogogn yũt

criança desmaiar PERF

a criança desmaiou

Em (7), gramatical com verbo ativo, indicando perfectividade.

(8) cem ba' yũt

noite frio PERF

a noite já está fria

(9) cem ba' yũt-ãm

noite fria PERF-TEL

a noite já está fria

Em (8) e (9) o marcador ocorre com verbo estativo $b a^{\prime}$ (estar frio), indicando presente perfeito, o que significa que o marcador de perfectividade pode ser usado com este tipo de verbo. Como veremos abaixo, é típico que morfemas verbais de perfectividade usados com verbos estativos, em idiomas com esse tipo de verbo (equivalente aos adjetivos das línguas europeias), passem a indicar estado presente ${ }^{15}$ resultante de uma transformação no passado. Em (9) o marcador coocorre com o marcador -ãm (ingressivo).

\footnotetext{
${ }^{15}$ Será usado neste trabalho o termo 'presente' na descrição de aspecto por uma questão de praticidade, o que se refere com esse termo será o momento de referência, e não o momento da fala.
} 
Verbos estativos (equivalentes a adjetivos) foram analisados especificamente com cada morfema para verificarmos que mudança de efeito a categoria verbal estativa teria no aspecto conferido por um dado morfema.

Essa abordagem se baseou na mudança de efeito do marcador de aspecto em verbos estativos em outros idiomas tipologicamente similares ao Dâw (isolantes e com marcação aspectual por partículas independentes), como o chinês mandarim, em que o marcador de perfectividade le com verbos ativos indica ação completa, perfectiva, mas com verbos estativos indica estado presente que resultou de uma mudança ( $\operatorname{ta}$ gāo = 'ele é alto; ta gão le = 'ele ficou alto, cresceu'), e com verbos psicológicos tipicamente não ocorre ou tem uma conotação de perfeito, ou seja, estado ainda presente resultante de uma transformação no passado. Efeito similar tem o marcador de perfectivo do tailandês leew ou o vietnamita đã, que indicam ação perfectiva completada com verbos ativos, mas com verbos estativos indicam estado atingido como resultado de transformação.

Pudemos verificar que no Dâw essa mudança de efeito do morfema com base na categoria verbal também ocorre, pois o estativo $b a^{\prime}$ acima como o marcador yũt é interpretado como 'está frio', 'ficou frio', ou seja, estado presente resultado de uma transformação.

\section{(10) 'ãr po dâr yũt topyõr wap}

$1 \mathrm{sg}$ abrir bater PERF porta todas

eu abri todas as portas

Em (10) ele coocorre com o morfema dâr (passar), que pode ser um marcador de aspecto que ocorre apenas com certos verbos transitivos.

(11) 'ãr daad paar yũt-ãm

1 sg escrever saber PERF-TEL

eu já sei escrever

Em (11) o composto yũtãm ocorre com verbo cognitivo 'saber', mostrando a compatibilidade do marcador de perfectivo com verbos dessa natureza semântica, mas adotando um significado de estado presente atingido possivelmente por transformação. 
Em chinês um verbo cognitivo como zhīdao 'saber' também não é traduzido como 'eu sabia' com o marcador de perfectivo; ao invés disso, ele adquire um significado de 'passar a saber' com o marcador de perfectivo -le: wǒ zhīdao le 'eu sei, passei a saber, aprendi (antes não sabia). Para expressar 'eu sabia' em chinês diz-se apenas wǒ zhīdao, opcionalmente com advérbio de tempo passado.

\section{(12) dâw'ãy dôo' âg yũt dâwtee-ũuy nâx mulher CAUS beber PERF1 criança-AFET água a mulher já fez a criança beber água}

Em (12) o morfema yũt 'perfectivo 1' de Martins ocorre em construção causativa do âg 'fazer beber'. Tanto o causado (agente de 'beber') quanto o objeto do verbo ocorrem depois ao composto verbal causativo mais marcador de aspecto.

\section{(13) tir wuแd 'ãr rãm yũt nã \\ 3sg chegar 1sg ir PERF FUT \\ quando ele chegar eu já terei ido}

\footnotetext{
‘ãm yâa dâwtee weed yũt nã nãk

2sg vir criança comer PERF FUT açaí

quando você vier, a criança já vai ter comido açaí
}

Em (13) e (14) o morfema marca futuro anterior, com o marcador de futuro nã.

Em (13) o marcador de aspecto ocorre entre o verbo rãm 'ir (embora)' e o marcador de futuro opcional nã. Como se espera na perfectividade no tempo futuro, a tradução é 'terei ido', como ocorre nas línguas eslavas, em que um verbo perfectivo no futuro tipicamente corresponde ao nosso futuro anterior 'terei feito'.
(15) bub rid weed yũt
amanhã 3pl comer PERF
amanhã eles já terão comido 
O morfema também pode ocorrer no futuro anterior sem nã , já que tempo não é morfologia obrigatória em Dâw.

(16) *but yũt-or nâx

despejar PERF1-IMP água

despeje água!

(17) *wam-õr yũt wãnpis

amolar-IMP PERF1 faca

amole a faca!

As sentenças (16) e (17) mostram que o marcador é agramatical com o marcador de imperativo -or, seja esse sufixo colocado no marcador de aspecto ou no verbo.

(18) tir xupwoc yũt

3sg assustar PERF1

ele se assustou

(19) tir xupwoc yũt.ãm

3sg assustar PERF1-TEL

ele se assustou

Em (18) e (19) vemos que pode ocorrer sozinho ou com -ãm (ingressivo) com o verbo cognitivo 'assustar-se'.

(20) *be lôok yũt tuu

pau furar PERF1 chão

o pau furou o chão

Em (20), o morfema é agramatical com o verbo transitivo 'furar'. Com esse verbo, bem como com vários verbos que denotam ações súbitas, os falantes preferem o marcador dâr ('pontual'), ou xâd ('durativo') se o verbo for intransitivo.

(21) * ‘ãr weed yũt dep wâat wap 
1sg comer PERF carne dia todo

(22)

\section{* dâwtee 'õt yũt wâat wap}

criança chorar PERF dia todo

(23) * ‘ãr weed yũt têen

1sg comer PERF agora

\section{*‘ãr pis tẽn 'ãr âg yũt lêc}

1sg pequeno quando 'sg beber PERF leite

quando eu era pequeno eu bebia leite

Nas sentenças de (21) a (24) vemos que o marcador é agramatical quando a ação é habitual e imperfectiva, como é de se esperar. Essa é uma das principais evidências de perfectividade, pois se meramente fosse um advérbio como 'já', seria compatível, ao menos em tese, com habitualidade, como temos 'eu já chorava muito' ou 'quando era pequeno, já comia carne todo dia'. O advérbio ‘já' é compatível com a imperfectividade e a habitualidade, mas um verdadeiro marcador de perfectividade não é.

\section{(25) *dâwtee 'õt yũt pud yedêe' criança chorar PERF muito INTS.PASS}

Em (25) vemos a agramaticalidade da ocorrência de yũt com o marcador de passado sufixal êe', que tende a ser tarduzido pelo pretérito imperfeito.

*top yẽw yũt

casa boa PERF

\section{(27) *tir cik yũt}


3sg sujo PERF1

(28) *tir weey yũt

3sg fraco PERF1

(29) tir pis yũt

3sg pequeno PERF1

ele ficou pequeno

(30) tir peg yũt

3sg grande PERF1

ele ficou grande/já cresceu

(31) tir wum yũt

3sg forte PERF1

ele ficou forte

De (26) a (31) vê-se novamente que o marcador é compatível com alguns verbos estativos, como pis (pequeno), peg (grande) e wum (forte) mas não com outros, como yẽw (bom), cik (sujo) e weey (fraco). Talvez isso seja uma questão idiomática, arbitrária, não inerente à semântica dos verbos estativos em questão. Nas sentenças em que é gramatical, observa-se mais uma vez que o efeito do marcador de perfectividade yũt com verbos estativos é de 'perfeito', um estado presente devido a uma transformação passada 'ele ficou grande $>$ ele está grande'. Sem o marcador yũt, o falante mais naturalmente intepretaria a sentença tir peg (3sg grande) como 'ele/ela é grande' (embora a intepretação 'está grande’ não fique descartada).

(32) tir weed-ẽr yũt

3sg comer-NEG PERF1

ele não comeu

(33) tir weed yũt-ẽr 


\title{
3sg comer PERF1-NEG
}

ele ainda não acabou de comer

(34) tir âg yũt-ẽr nâx

3sg beber PERF1-NEG água

ele não conseguiu tomar água

Em (32) e (33) vê-se o efeito da mudança de posição do morfema de negação -ẽr. Quando este aparece no verbo, indica apenas a ação verbal perfectiva negada; quando é sufixado ao marcador de aspecto, designa a não conclusão da ação, com verbos transitivos e intransitivos. Isso sugere que além de perfectividade, yũt talvez possua uma coloração de completivo, de 'terminar'.

Decidimos também pesquisar ao corpus das Narrativas Dâw, coletadas nos primeiros trabalhos de campo, devido à sua riqueza de sentenças espontâneas, para ver até que ponto falantes produzem, sem serem incentivados a fazê-lo, os diversos marcadores investigados neste trabalho. No caso de yüt, pudemos confirmar que se trata de um morfema amplamente usado, ocorrendo em dezenas de sentenças, dadas a seguir a partir de (35). As narrativas, contudo, não contam com glosas, que foram adicionadas somente neste trabalho.

\author{
abug tir nê yũt mãr \\ daí 3sg fazer PERF1 EVID.REPORT \\ dizem que ele já tinha terminado de fazer a roça
}

$\mathrm{Na}$ sentença (35) temos um exemplo traduzido pelo falante nativo como passado anterior (mais que perfeito).

(36) bug tir weed yũt bug rid 'wây rãm taaw bug tir yũt yêd tir tôog-ũúy' aí 3sg comer PERF1 aí 3pl ver ir matapi aí 3sg PERF1 INTS1 3sg filhaAFET

então (ele) acabou de comer, aí o pai levou a sua filha para ver matapi

(37) tee $\tilde{\text { úty }} \mathbf{y}^{\prime}$ yũt yed kâ' 
jovem descascar PERF1 INTS1 abacateira

o jovem descascou o pé de abacate

Em (36) e (37) temos mais exemplos de perfectividade.

$$
\text { 'ãr peem xâd 'ãr winh yũt-ẽr } \quad \text { uy bug 'ãr winh yũt-ẽr }
$$

1sg sentar DUR 1sg trabalhar PERF1-NEG porque aí 1sg trabalhar PERF1-NEG agora eu estou sentada porque eu não consigo mais trabalhar, eu não consigo mais trabalhar,

\section{têen mẽenh kaaw suun 'ãr kas rãm uy}

agora 1 sg.poss roça nem $1 \mathrm{sg}$ ruim ir porque

nem a minha roça, porque eu me estraguei

Em (38) temos um exemplo interessente, em que o marcador yũt negado é traduzido como 'não conseguir'.

(39) tir kon yũt-ẽr

3sg cavar PERF1-NEG

ele não consegue cavar

Em (38) mais uma instância em que o yũt negado é traduzido como não conseguir, talvez por não completar ação.

(40) ãr wây yũtãm 'muнy nãa mãr

1sg ver PERF1-TEL 2sg.OBJ dizer EVID.REPORT

"Agora eu te vi", disse

Em (40) temos mais uma coocorrência de yũt com o -ãm, indicando o que parece ser mera perfectividade.

Enfim, fica claro que o morfema yũt resulta da gramaticalização do verbo Dâw 'matar' em construções concatenativas, 'matar comer' > 'terminar de comer' espelhando nossa expressão em português 'matar uma cerveja' ou 'matar uma questão', finalmente se tornando um mero marcador de perfectividade verbal, função que nos parece 
amplamente confirmada nas amostras analisadas nesta seção, com uma nuance de terminativo e com um pouco de modo potencial, nas sentenças em que, quando negado, exprime 'não consegui'.

\subsubsection{Perfectivo 2 rü' (quantificador)}

Derivado do verbo rũ' 'acabar', 'terminar', segundo Martins marca eventos 'estendidos a uma entidade vista como completa, com foco em cada elemento do conjunto'. Ainda segundo a autora, esse morfema quantifica o argumento objeto do verbo transitivo e o sujeito do verbo intransitivo. Sentenças de (1) a (4) retiradas dw Martins, 2004.

(1) tir nê rũ' cem 3SG fazer PERF2 noite ele fez tudo à noite.

(2) tir mẽ' dó’ rũ' tir rẽd-‘̃̃uy 3SG mãe Mov PERF2 3SG posse-coletânea a mãe dela tirou toda a bagagem dela

(3) tir xâd rã' sãmãr top but 3SG procurar PERF2 xamã casa em ele procurou tudo na casa do Xamã

(4) nâxpog xop rãm rũ ' rio secar ir PERF2 o rio secou por completo

De (5) a (12), sentenças das amostras de 2013/2014:

(5) *ã̃r ãa r $\tilde{\mathbf{u}}^{\prime}$ 1sg dormir PERF2 
Em (5), determinamos, com base em testes posteriores, que a fonte da agramaticalidade deve ser a singularidade do argumento verbal, um pronome de $1^{\text {a }}$. pessoa singular. Como não é possivel alguém não dormir inteiro, a sentença fica agramatical, pois $r \tilde{u}$ ' fica redundante. Se o sujeito fosse 'id (nós), a sentença ficaria gramatical e com interpretação 'todos nós dormimos'.

(6) 'ãr weed rũ ' yoon

1SG comer PERF2 tamanduá

eu comi todo o tamanduá

(7) 'ãr weed $\mathbf{r} \tilde{\mathbf{u}}$ '

1SG comer PERF2

eu comi tudo

(8) 'ar weed rũ ' ruul'

1SG comer PERF2 cupuaçu

eu comi todo o cupuaçu

Além disso existe uma forma composta: $r \tilde{u}^{\prime}+y \tilde{u} t+\tilde{e} r>$ rũyũtẽr $>$ rũyer, com o sentido de não ter conseguido realizar uma ação:
(9)

dâw mãy-nê $\quad$ rũy-ẽr 'á'
pessoa pagamento-fazer $\mathrm{PERF-NEG} \mathrm{esse}$
a pessoa não conseguiu pagar tudo isso aí

Notamos que essa negação, que vale para ambos os marcadores, não denota uma ação imperfectiva, e sim uma ação perfectiva negada. Por exemplo, veja (10), perfectiva e negada.

(10) rid xu rũy-ẽr kuj bug

3PL descer PERF-NEG nunca lá

eles não conseguiram descer mais de lá 
Os dois perfectivos, yũt e rü', segundo Martins, (p. 327) dão enfoques diferentes à completude do evento, com yũt focalizando 'a estrutura interna do evento como uma unidade completa' e rü' enfatizando a 'extensividade do evento a cada uma das unidades do conjunto que forma o todo'.

Na presente análise a conclusão é de que o marcador yũt marca perfectividade e o morfema $r \tilde{u}^{\prime}$ tem semântica de quantificador universal do sintagma nominal mais próximo do verbo - sujeito para verbos intransitivos e objeto para verbos transitivos não necessariamente para indicar uma ação verbal perfectiva, sendo compatível com predicados imperfectivos, embora sua semântica geralmente télica implique em predicados normalmente perfectivos.

No trabalho de campo de 2015, foram aplicados testes mais detalhados para determinar se esse morfema tem traços de marcador de perfectividade, se pode ser usado para traduzir sentenças em português com verbos no imperfeito, sentenças com objetos diretos sem quantificação universal, e sentenças com o quantificador universal nominal wap (todo, todos) bastante usado no idioma.

(11) tir weed yũt yoon ye'

3SG comer PERF1 tamanduá bucho

ele já acabou de comer o bucho do tamanduá

(12) tir weed rũ' yoon ye'

3SG comer PERF2 tamanduá bucho

ele comeu todo o bucho do tamanduá

Em (11) ele pode ter parado de comer antes de comer o bucho inteiro, mas em (12) não.

Foi confirmado no trabalho de campo de 2015 que esse morfema tem como função principal a quantificação universal do argumento mais próximo do verbo, e apenas parece em certos casos indicar perfectividade ou até telicidade porque esses conceitos estão associados a eventos que afetam por completo algum dos argumentos verbais. 
Em função quantificadora, o morfema rü' compete com o morfema wap, de mesma função, mas que ocorre no sintagma nominal. Não foi detectada diferença semântica significativa entre o uso dos dois, em frases como tir tuk rũ' [3sg querer PERF2] e tir tuk kaswap [3sg querer coisa.tudo] 'ele quer tudo'.

A partir de (13) abaixo temos as elicitações de 2015.

A série de elicitações de (13) a (29) e algumas posteriores ilustram bem a interação entre $r \tilde{u}$ ', wap, negação e quantificação universal parcial e nula:

(13) rid wap yok

3 pl todos nadar

eles todos nadaram

(14) rid wap yok rãm cem

3 pl todos nadar ir ontem

eles todos foram nadar ontem

(15) rid yok rũ' bub

3pl nadar PERF2 amanhã

amanhã todos eles vão nadar

(16) rid yok rũ'-ẽr bub

3pl nadar PERF2-NEG amanhã

amanhã nem todos eles vão nadar

(17) rid wap yok rũ' bub

3pl todos nadar PERF2 amanhã

eles todos vão nadar amanhã

(18) rid wap yok-ẽr bub

3pl todos nadar-NEG amanhã

nenhum deles vai nadar amanhã 
(19) rid yok rũ'-ẽr bub

3pl nadar PERF2-NEG amanhã

nem todos vão nadar

(20) rid wap yok rũ'-ẽr bub

3pl todos nadar PERF2-NEG amanhã

nem todos foram nadar

(21) rid weed rũ'-ẽr

$3 \mathrm{pl}$ comer PERF2-NEG

nem todos comeram

(22) rid wap weed-ẽr

3 pl todos comer-NEG

ninguém comeu

(23) rid wap weed rũ'-ẽr

$3 \mathrm{pl}$ todos comer PERF2-NEG

nem todos comeram

(24) 'id wây xaaylãs

$1 \mathrm{pl}$ ver carro

nós vimos os carros

(25) 'id wây xaaylãs wap

$1 \mathrm{pl}$ ver carro todos

nós vimos todos os carros

(26) 'id wây rũ' xaaylãs

1pl PERF2 carro

nós vimos todos os carros

(27) 'id wây rũ'-ẽr xaaylãs

1pl ver PERF2-NEG carro 
não vimos todos os carros (apenas alguns)

(28) 'id wây-ẽr xaaylãs waap-ũuy

$1 \mathrm{pl}$ ver-NEG carro todos-AFET

não vimos nenhum carro

(29) 'id wây rũ'-ẽr xaaylãs wap

1spl ver PERF2-NEG carro todos

não vimos todos os carros

Vemos em (29) que rũ pode coocorrer com wap, que, aliás, é bastante comum.

Nas sentenças de (30) a (32) abaixo vemos que rũ' não pode ocorrer antes do verbo, e wap pode. Isso indica que ocorre no sintagma verbal, ao passo que wap vem no sintagma nominal.

(30) cem dâw'ây wap yam

ontem mulher todas dançar

ontem todas as mulheres dançaram

(31) *cem dâw'ây rũ' yam

ontem mulher PERF2 dançar

(32) cem dâw'ây yam rũ'

ontem mulher dançar PERF2

ontem todas as mulheres dançaram

Vemos também na série de (13) a (29) acima que o morfema de negação verbal -ẽr pode vir sufixado tanto ao verbo quanto ao morfema $r \tilde{u}$ '. Quanto sufixada a $r \tilde{u}$ ', o sentido obtido passa de quantificação universal para quantificação parcial, p. ex. rid yok rũ ' [3pl nadar PERF2] 'todos nadaram', mas rid yok rũ'-err [3pl nadar PERF2-NEG] 'nem todos nadaram'. Se a negação for sufixada ao verbo, o sentido é de quantificação nula, geralmente enfatizada pelo quantificador universal nominal wap ('todos'), p. ex. rid 
wap yok-ẽr rũ' [3pl todos nadar-NEG PERF2] 'eles todos não nadaram/ nenhum deles nadou'.

Note que o quantificador universal wap indica a totalidade de uma série, sempre portanto melhor traduzido no plural 'todos/todas'. A noção de integralidade (todo, inteiro) é expressa pelo lexema posposto rew (inteiro), portanto dep wap seria 'todas as carnes' mas 'a carne toda' é dep rew. Já rũ pode exprimir tanto totalidade plural quanto singular (integralidade) - portanto seria melhor denominado de totalizante.

De qualquer modo não é perfectivo nem télico, pois é gramatical no passado habitual em ações prolongadas, como na sentença atélica (33):

\section{(33) rid pis rid wap yok rũ'}

$3 \mathrm{pl}$ pequeno $3 \mathrm{pl}$ todos nadar PERF2

eles todos nadavam quando eram pequenos

E ocorre, ainda, com verbos atélicos em sentenças como ‘eles todos nadaram' ou 'eles todos estão nadando', como vimos nas sentenças de (15) a (21) acima.

Em (34) podemos ver que o morfema rũ ' também pode ser usado com verbos estativos, sendo traduzido como 'tudo'.

\section{(34) yẽw rũ' \\ bom PERF2 \\ está tudo bem}

A sentença acima também pode ser expressa com o quantificador nominal, kaswap yẽw, comumente usada em conversação como 'tudo bem?'. Note que neste caso o kaswap (coisa.tudo > tudo) precede o verbo como seu sujeito, ao passo que rü' deve aparecer no slot após o verbo como os verbos modais e outros concatenativos ${ }^{16}$.

Listamos a seguir algumas ocorrências no corpus de Narrativas Dâw.

\footnotetext{
${ }^{16}$ A maior parte dos verbos concatenativos, modais, auxiliares, como tuk (querer), paar, ocorrem após seus verbos principais.
} 
(35) yaak nãak nãpay nĩ rũ' têen 'id-ẽej

mandioca açaí isso.que existir PERF2 agora 1pl.POSS

mandioca, açaí, agora a gente tem tudo

(36) yẽew rãm rũ' têen 'idi'

diferente ir PERF2 agora 1pl-?

agora todos nós somos diferentes

(37) têen dâw yẽew rãm rũ' aa'

agora dâw diferente ir PERF2 isso

agora todos os dâw mudaram

(38) bug tir rãm kor tên aa' ray mãy êe' mãr waar rũ' êe'

aí 3 sg ir .....

... não maduro PERF2 PASS

aí quando ele foi na primeira estava tudo verde

Em (38) vemos uma curiosa coocorrência de $r \tilde{u}$ ' com o marcador de passado êe', que não aparece sufixado ao verbo estativo waar (não maduro, verde) e aparece após o marcador rü'. Talvez o que Martins classificou como marcador de passado sufixal também ocorra como morfema separado, um clítico talvez.
wâa' rũ'-ẽr
rã'
ouvir PERF2-NEG 1sg.FOCO

eu não ouvi todas

Em (39) mais um exemplo em que a negação - $\tilde{e} r$ sufixada a $r \tilde{u}$ ' gera sentido de quantificação parcial.

(40) 'abug yawi 'yãm.xu' kasãm rũ' mãr

aí errar onça morrer PERF2 EVID.REPORT

é aí que quase todas as onças morreram 
Em (40) temos um exemplo de sentença rü' traduzido como 'quase todas', provavelmente devido ao verbo yawi ('errar') que pode ocorrer como partícula indicando frustração ou não conclusão da ação.

(41) nĩ'uy dâw rũ' rãm kâ'

por.isso dâw PERF2 ir OPINATIVO

é por isso que os dâw quase acabaram

(42) aag 'nãgn ray weed dâr rũ' tir wap ridũuy

aí esse engolir comer PONT PERF2 3sg todos 3pl-AFET

esse daí engoliu e comeu todos eles

(43) rũu' weed rũ' yêd mãr

dizer comer PERF2 INTS1 EVID.REPORT

é, dizem que comeu todos eles

Finalmente em (44) temos um exemplo que contradiz a aplicação da quantificação universal ao objeto do verbo transitivo, pois o sujeito aparece quantificado, embora essa quantificação também seja realizada pelo quantificador universal nominal wap.

(44) rid wap po dâr rũ' xas-ũuy'

3pl todos abrir PONT PERF2 caixa-AFET

eles todos abriram as caixas

Em (45) temos um caso de agramaticalidade no morfema em uma sentença com adverbial habitual:

(45) *wât wap 'ãr weed rũ' nãk

todo dia 1sg comer PERF2 açaí

Embora $r \tilde{u}$ ' não pareça ter uma aspectualidade perfectiva, ele tende a ser traduzido com o nosso pretérito perfeito, talvez por que a semântica quantificadora universal seja mais compatível com predicados perfectivos. 
Num primeiro momento, ao analisarmos esse morfema, suspeitamos de traço de ergatividade no idioma, já que a aplicação da propriedade quantificadora desse morfema ao argumento sujeito dos verbos intransitos e ao argumento objeto soa como ergatividade. Parecia inusitado um morfema verbal apresentar um alinhamento desse tipo, numa língua nominativo-acusativa.

Mas devido à origem lexical do morfema como o verbo 'terminar' do idioma, podemos especular por meio de teste com a tradução original do morfema, i.e., "acabar" ou "terminar", e vemos que a natureza quantificadora universal desse verbo também tende a se aplicar ao argumento objeto do verbo transitivo, mesmo quando em tese o argumento sujeito poderia ser quantificado. Vemos também que é natural esperar que esse morfema passe de verbo 'terminar' a quantificador, já que a semântica de terminar é associada à quantificação.

Ou seja, não se trata de ergatividade, mas sim de aplicação da propriedade quantificadora do verbo 'terminar' ao argumento mais próximo do verbo, que nos verbos transitivos é o argumento objeto.

O verbo 'terminar', com objeto direto ou concatenativo (seguido de verbo), é télico. A definição de télico é aquilo que só se torna verdadeiro quando termina, e de atélico que ao começar já é verdadeiro - p. ex. 'ele nadou': ao começar de nadar, isso já é verdade, ele nadou 20 metros - isso só se torna verdade ao serem completados os 20 metros. Mas 'ele terminou de nadar' só é uma afirmação verdadeira quando ele cessou a atividade, em seu final, tanto quando ele terminou de nadar os 20 metros. Assim, no progressivo 'ele está terminando de escrever' não significa que 'terminou de escrever', prova de que o verbo terminar implica necessariamente em telicidade. Supomos que em Dâw o verbo $r \tilde{u}$ ' tenha essa mesma propriedade.

Quanto à quantificação dos argumentos nominais do verbo, esta também seria uma consequência de qualquer verbo com semântica de 'terminar, concluir', na nossa hipótese, o que explicaria a gramaticalização de $r \tilde{u}$ ' como quantificador dos argumentos do verbo. 
Pois uma expressão como 'ele terminou de comer as maças' é virtualmente indistinguível de 'ele comeu todas as maçãs'. Uma construção transitiva em que sujeito e objeto sejam igualmente quantificávels, como 'eles terminaram de comer as maçãs' ainda sim parece implicar na quantificação do objeto mais do que do sujeito, pois é possível interpretar como 'num grupo de 10 pessoas, 9 comeram as maçãs todas'mas não 'todas as pessoas comeram 9 do total de 10 maças'.

Ou seja, embora haja inúmeras questões a resolver, o morfema rü' parece assim bem menos exótico, já que significa, como item lexical independente, 'terminar', conceito ligado à quantificação universal, a partir do qual foi se gramaticalizando, talvez sob a influência de outros idiomas indígenas do local, como o Tukano, que também usa um auxiliar significando 'acabar' para quantificar o argumento mais próximo do verbo. Quando um verbo tem um objeto direto (especialmente + definido) o quantificador alojado no sintagma verbal mais naturalmente se aplica a esse objeto do que ao sujeito.

A gramaticalização de verbos 'terminativos' também se verifica em chinês, onde o verbo wan 'terminar' está quase gramaticalizado, incorporado ao leque de partículas aspectuais do idioma, geralmente usado em associação ao perfectivo le, e ao contrário dos verbos concatenativos do idioma, aparece gramaticalizado após o verbo: wǒ chiwan le [1sg comer-terminar PERF] 'eu terminei de comer', que também pode ser traduzido por 'eu comi tudo'; tâ xiē-wan xīn le [3sg escrever-terminar carta PERF] 'ele terminou de escrever a carta, escreveu a carta toda'. Seria interessante averiguar até que ponto essa construção chinesa implica em quantificação nominal dos argumentos do verbo no idioma. De qualquer maneira, especulamos aqui que parece bem comum nos idiomas do mundo que um verbo ou morfema verbal com semântica terminativa passe à função de quantificador nominal dos argumentos do verbo.

Na seção 4.3 veremos como um caminho ainda mais similar ao do rü' em Dâw foi trilhado pela partícula verbal saai em Cantonês ${ }^{17}$, cujo significado começou como 'terminar' e hoje talvez desempenhe uma função quantificadora dos argumentos nominais do verbo: ngo sik saai pinggwo [1sg comer COMPL maçã] 'eu terminei de comer a(s) maçã(s)' ou 'eu comi a(s) maçã(s) toda(s)'. E, como rũ' em Dâw, em

\footnotetext{
${ }^{17}$ Teng, 1996, Aspectuals in Cantonese, the case of saai, in UCLWorking Papers in Linguistics 8.
} 
Cantonês a partícula saai significa 'tudo' com um verbo transitivo usado intransitivamente como 'comer': ngo sik saai [1sg comer COMPL] 'eu comi tudo, 18 . Fenômenos similares em línguas indígenas do Alto Rio Negro já foram expostos acima.

Vale incluirmos aqui uma discussão sobre a interação entre quantificação e aspecto. Em “Quantification, Aspect and Lexicon” (1996), Hana Filip argumenta que as línguas diferem na variedade de estruturas quantificadoras que utilizam, bem como no grau em que as formas superfícialmente realizadas das várias estruturas quantificadoras fornecem indícios de interpretação semântica. As estruturas semânticas de sentenças com um único quantificador podem ser determinadas pela estrutura do sintagma sozinha ou junto com informações sobre tópico ou foco. Em caso de ambiguidade, o contexto extra-linguístico pode ser utilizado, mas também pode ser usada a estrutura argumental, como em idiomas nos quais o principal elemento quantificador é um operador V lexical, que, segundo a autora, funcionam como quantificadores em predicados episódicos e seus argumentos.

Esses operadores ligariam a variável do Tema Incremental e possivelmente a variável de Evento. Sem a existência de Tema Incremental, a quantificação se aplica somente à variável de evento, na ausência de ambas variáveis a quantificação é indeterminável. A autora baseia suas conclusões, entre outros, em dados do Tcheco, idioma eslavo em que não existem artigos (nem outro morfema de definição nominal) e no qual o aspecto é expresso por meio de afixação verbal. Ela demonstra, como outros autores, que o aspecto verbal acaba afetando a definição e a telicidade dos seus argumentos. O objeto direto de um verbo perfectivo tem uma probabilidade maior de ser definido ou contável, gerando com o verbo um evento télico.

Devemos apresentar aqui a distinção entre:

Quantificação D - ocorrem no sintagma nominal - "todos, cada, nenhum, alguns, a maioria, poucos".

\footnotetext{
${ }^{18}$ Lee, 2012, Cantonese Particles and Affixal Quantification, p. 51 et. seq.
} 
Quantificação A - ocorrem no sintagma verbal - "geralmente, sempre, raramente, nunca”; certos quantificadores flutuantes como 'ambos' e 'todos' que podem ser D podem pular para essa categoria (ver 'todos os homens sabem isso' e 'os homens todos sabem isso') e verbos auxiliares e outros afixos verbais. (Partee, Bach, Kratzer, 1987; Bach, et al. 1995).

Boa parte das distinções de quantificação pode ser expressa com ambos os tipos:

c1) triângulos sempre têm três lados (quantificação A) ou

c2) todos os triângulos têm três lados (quantificação D) ou

c3) os triângulos todos têm três lados (A) ou

\section{c4) os triângulos têm todos três lados (A)}

Vemos que no Dâw existem ambos os tipos de quantificação, sendo que wap (todos) e rew (inteiro, todo) são " $\mathrm{D}$ ” e $r \tilde{u}$ ' seria um dos quantificadores do tipo " $\mathrm{A}$ ”, que ocorrem no sintagma verbal.

Com toda probabilidade, baseado nos dados ainda limitados de que dispomos, o morfema r $\tilde{u}^{\prime}$ é um quantificador verbal (tipo A) que começou lexicalmente como o verbo de fase 'terminar' e que, devido às implicações aspectuais e quantificadoras da semântica desse verbo, passou cada vez mais a ter uma implicação quantificadora nominal, e pode estar passando por um processo de migração da categoria A (verbal) para a D (nominal). No Hup, o cognato hũ ('terminar') estaria numa fase mais incipiente desse processo, ainda ocorrendo opcionalmente de forma reforçadora com o morfema verbal $-y \dot{t}$, chamado por Epps de 'télico'. No Tukano houve uma gramaticalização completa com sentido de quantificação universal, como em Dâw.

Decidimos não denominar esse morfema de télico, ao contrário do que ocorreu com yi em Hup em Epps (2006), porque o morfema pode ocorrer em sentenças como (33) acima, que são atélicas. 


\subsubsection{Frustrâneo wuud}

Do verbo equativo wutd 'era, possibilidade de ser, ou não ser na íntegra, não ser mais como antes', e como marcador de aspecto, exprime eventos que não se realizaram por completo, que não atingiram o objetivo (Martins 2004).

Esse tipo de categoria ocorre em diversos idiomas amazônicos e é chamado de modo frustrativo por outros autores, como Aikhenvald (2012). Nossa hipótese é que em Dâw trata-se também de modo, e não aspecto.

(1) tir kâs dôo' wuud wa'ũuy' wa' nã xâd 3SG moder MOV FRUST urubu-AFET urubu voar passar ele queria morder o urubu, mas o urubu voou.

(2) tir se' dôo, ${ }^{19}$ pis wutd tir se'báx 3SG carregar-paneiro MOV ser pouco:AUM FRUST 3SG paneiro ele tentou carregar o paneleiro dele muitas vezes, mas não conseguiu.

(3) tir mẽ' dôo' 'uub pĩs wutd tir 'uubẽr kuj 3SG mãe MOV acordar pouco FRUST 3SG acordarNEG nunca a mãe dela tentou de todo jeito acordá-la, mas ela não acordou mesmo

(4) 'a 'yãmxu' kâs dôo' wâ' wưdu' isso onça morder ir-à-frente FRUST avó-AFET isso foi antes de a onça morder a avó, mas ela não morreu

19 O morfema dôo' (glosado MOV) é indicador de movimento, além de ocorrer como verbo causativizador 
Segundo Martins (Martins 2004 p. 309) a distinção entre o imperfectivo $t a^{\prime}$ e o frustrâneo wuttd é traçada claramente no idioma, e esses dois aspectos podem se combinar:

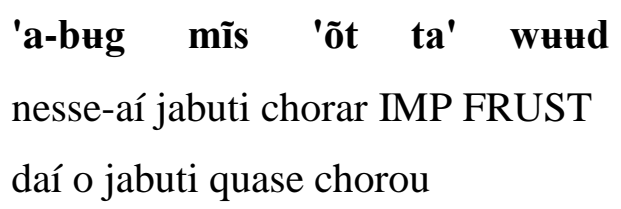

Como os dados de 2014 puseram em questão a pertinência de $t a^{\prime}$ como marcador de aspecto imperfectivo em Dâw, e também indicaram que ele teria caído em desuso, em julho de 2015 realizamos testes sobre qual interpretação os falantes do idioma dariam para frases combinando $t a^{\prime}$ com outros aspectos, e os falantes confirmaram claramente que o marcador $t a^{\prime}$ não é mais usado como indicador de aspecto.

Ocorrências de wzzd na amostra de julho de 2015:

(6) cem 'ãr yũt tuk wutd naap

ontem 1sg matar querer FRUST barata

ontem eu ia matar barata

(7) cem tir weed wutd

ontem 3sg comer FRUST

ontem ele ia comer

Aqui se vê a tendência do frustativo de se equivaler ao modo condicional das línguas europeias. A tradução condicional ('ia fazer, faria') é a mais comum para o marcador de fustrativo com verbos ativos, especialmente acompanhada do verbo tuk (querer), como visto em (6) acima e no resto das amostras.

(8) 'ãr yũt-ẽr te wutd naap

1sg matar-NEG PROG3 FRUST barata

eu não tinha matado barata 
Aqui nota-se que a combinação do progressivo 3 (tee, geralmente traduzido como 'ainda') com o frustrativo gerou uma tradução, por parte do falante nativo, como mais que perfeito 'tinha matado'. Como a ação foi frustrada, o morfema foi utilizado aí.

(9) tir yãm wutd

3sg dançar FRUST

ele estava dançando

Noate-se em (9) com verbo ativo, a tradução no pretérito imperfeito, e não no frustrativo nem no condicional, isso talvez seja a leitura original como descrito por Martins, 'era, possibilidade de ser, passado'. O uso do morfema com verbos estativos está ilustrado de (10) a (21) abaixo.

(10) bertâg tas wutd

árvore torta FRUST

a árvore era/estava torta

(11) bertâg tas tuk wutud

árvore torta querer FRUST

a árvore quase ficou torta

(12) dâwtee dep wutd

criança gordo FRUST

o menino era/estava gordo

(13) dâwtee depê'

criança gordo-PASS

o menino era/estava gordo

(14) cem ba' wutd

noite frio FRUST

a noite era/estava fria 
(15) * bub cem ba' wutd

amanhã noite frio FRUST

(16) Báal taw peg pud wutd

Manaus cidade grande muito FRUST

Manaus era uma cidade grande

(17) top yẽw wutd

casa boa FRUST

a casa era boa

(18) tir weey wutd

3sg fraco FRUST

ele era/estava fraco

(19) dâwtee pis wutd

criança pequena FRUST

a criança é pequena

(20) wéed mãypeg wuษd

comida cara FRUST

a comida era cara

(21) wéed kas wutd

comida ruim FRUST

a comida estava ruim

Nas sentenças de (10) a (21) se observa o uso do morfema para indicar o tempo passado com verbos estativos, que perfazem a função de adjetivos em Dâw. Em (13) verificamos que o marcador glosado como 'passado' por Martins (êe') também serve igualmente para indicar passado de verbos estativos. Pode ser que este wztd que indica passado seja outro morfema. Martins considera como sendo o mesmo morfema, mas no léxico 
Dâw coletado nos trabalhos de campo anteriores o wuzd de 'passado, era' é apresentado como outro morfema. Para expressar o modo frustrativo com estativos em Dâw seria necessário usar o verbo tuk antes de wutd (22), (23):

(22) dâwtee dep tuk wutd

criança gorda querer FRUST

o menino ia ficar gordo

(23) 'ãr rãm wutd taw rid

1sg ir FRUST cidade para

eu ia pra cidade (mas não fui)

(24) 'ãr rãm-ẽr wutd taw rid

1sg ir-NEG FRUST cidade para

eu não ia pra cidade

* ‘ãr ram wutd-ẽr taw rid

1sg ir FRUST-NEG cidade para

Nas sentenças (24) e (25) observa-se a negação com wutt, que só pode ocorrer no verbo, ficando a expressão sem sentido se o sufixo negativo for posto no marcador wutt. Isso ocorre, provavelmente porque a negação da frustração significaria a realização da ação e ações frustrativas não podem ter sido realizadas.

(26) 'ãr po dâr wuud topyõr-ũuy

$1 \mathrm{sg}$ abrir PONT FRUST porta-AFET

eu ia abrir a porta

(27) 'ãr po dârẽr wutd topyõr-ũuy

1sg abrir PONT-NEG FRUST porta-AFET

eu não ia abrir a porta

Em (26) e (27) vê-se uma coocorrência com dâr (um dos morfemas analisados aqui, ver seção específica) produzida espontaneamente quando o falante foi estimulado a produzir 
a tradução da sentença portuguesa. $\mathrm{O}$ verbo 'abrir' po tipicamente é acompanhado pelo marcador dâr e então pode ser acrescido do modo frustativo wutt. A negação nesse caso é sufixada ao marcador dâr.

(28) bertâg kasãm wutd

árvore morrer FRUST

a árvore quase morreu

(29) bertâg yawi kasãm wutd

árvore errar morrer FRUST

a árvore quase morreu

Em (28) e (29) vemos que o verbo auxiliar yawi ('errar', que também indica frustração) pode ocorrer com verbo marcado com wutd sem alterar significativamente o seu sentido.

(30) 'ãr yok wutd mug

1sg nadar FRUST aqui

eu ia nadar aqui

(31) tir siib-ẽr wutd munh

3sg beliscar FRUST 1sg-OBJ

ele não ia me beliscar

(32) tir need wutd bug tir need-ẽr

3sg vir FRUST daí 3sg vir-NEG

ele ia vir daí não veio

De (30) a (32) temos mais exemplos claros de frustratividade.

(33) ‘ãr deel-ẽr wĩnh wutd

1sg poder-NEG trabalhar NEG

eu não podia trabalhar 
Em (33) o morfema ocorre com o verbo modal deel (poder), indicando meramente tempo passado. Sem o wztt essa frase tipicamente seria interpretada como presente, ou seja, 'ele não pode trabalhar'.

\section{(34) butor wutd nâx}

despejar FRUST água

não despeje a água

\section{(35) but wutd-õr nâx *}

despejar FRUST-IMP água

não despeje água

Aqui vê-se que wuttd não pode receber o marcador de imperativo, pois já é um modo, mas é compatível com o modo imperativo quando este é marcado no verbo. $\mathrm{O}$ fato de wนtd coocorrer com o modo imperativo e com o verbo modal deel 'poder' não implica que não é modal, já que a língua parece comportar, como muitas outras, mais de um morfema modal na mesma sentença.

\section{(36) dâwtee núu' winh'ĩi wutd \\ criança rato parecer FRUST \\ a criança parecia um rato}

Em (36) o falante conferiu o tempo passado à construção com um verbo 'parecer', que por ser não ativo talvez se comporte como os estativos e passe ao tempo passado com wutd, como nas amostras com estativos/adjetivos acima.

(37) tir xupwoc wutd

3 sg assustar FRUST

ele ia se assustar

(38) tir wâay'yar wutd dâwãy-ũuy'

3sg dizer-mentira FRUST mulher-AFET

ele ia mentir pra mulher 
Em (37) e (38) vemos a função frustrativa de wztd confirmada.

Sendo assim concluímos que wutd é um marcador de modo frustrativo, uma categoria ausente da lista de 'modos' da maioria dos trabalhos gerais sobre modo, mas já bastante presente e conhecida dos linguistas dedicados às línguas nativas das Américas. Se Martins estiver certa acerca do frustrativo ser uma forma mais gramaticalizada do morfema que glosa como 'era, passado', podemos dizer que wztud também tem uma função de passado imperfectivo, ou seja, um verdadeiro marcador TAM - tempoaspecto-modo.

Frustrativo é classificado como modo, e não aspecto, porque lida com indicação de mundos possíveis, hipótese e potencialidade. No seu uso no passado, a tradução sempre é no imperfectivo, o que nos faz concluir um traço de imperfectividade. E quanto ao tempo, quando o morfema o indica, é consistentemente o tempo passado. Contudo, nas amostras de 2015 apenas um verbo ativo, yam 'dançar' foi traduzido no passado com wztd. Todos os outros casos em que wztd foi traduzido como passado foram com verbos estativos, e para obtermos uma leitura frustrativa com estativos tivemos que usar o reforço de $t u k$ (querer).

O modo frustrativo em Dâw parece abarcar a função equivalente também ao 'modo condicional' observado em outras línguas, como visto nas amostras acima.

Os verbos modais em Dãw são tuk (querer) deel (poder) e pilsij (ter que, dever, precisar), estes dois últimos emprestados recentemente do verbo 'precisar' do português, sendo que tuk e pilsij podem levar objeto nominal diretamente. Só tuk é posposto ao verbo, por ser um lexema nativo do Dâw, idioma em que os verbos modais e concatenativos se seguem ao verbo, geralmente.

\subsubsection{Télico -ãm (ingressivo)}


Segundo Martins, é um sufixo e deriva do verbo rãm 'ir', tendo assumido a forma de sufixo devido a duas peculiaridades morfofonológicas do idioma Dâw: o processo de elisão de consoantes glotálicas em fronteiras de morfemas, e à regra que obriga morfemas iniciados em vogal a se tornarem afixos.

Segundo a autora, esse marcador codifica um evento cujo objetivo foi alcançado.

A nossa análise indica que codifica aspecto ingressivo, ou seja, a entrada no estado indicado pelo nome ou adjetivo/ verbo estativo, mas também aparece com outros verbos como indicador geral do que parece ser essencialmente perfectividade. Em (1) a (3) temos exemplos retirados de Martins (2004):

(1) 'á' yẽw pud rãm-ãm

esse ser bom Intensif. ir-TEL

isso ficou muito bonito mesmo!

(2) tir cem-ãm ${ }^{20}$

3SG noite-TEL

anoiteceu

(3) tir tug ned-ãm

3SG marido vir-TEL

o marido dela veio

A combinação adjetivo + rãm + ãm é extremamente comum em Dâw, com o verbo rãm formando ingressivos a partir de adjetivos (ficar bonito, ficar bom, etc) e a adição de ãm sendo traduzida nas amostras como passado perfeito (ficou bonito, etc.). Como vemos em (2), o morfema também pode ser usado diretamente com nomes, que indicam, tipicamente, algum estado no qual se pode entrar. A maioria dos exemplos de ocorrência de -ãm é com raízes adjetivais e nominais que indicam estado.

De (4) a (8), analisaremos exemplos dos trabalhos de campo de 2014:

\footnotetext{
${ }^{20}$ Nesta sentença observa-se bem a natureza não pro-drop do idioma: mesmo impessoal, ocorre com o pronome de $3 \mathrm{sg}$ tir.
} 
(4) tir tuk-ãm

3 sg querer-TEL

ele quer

Com o cognitivo 'querer' pode ser interpretado como ingressivo, significando que o sujeito entrou no estado de querer.

(5) tir ne-ãm top

3 sg fazer-TEL casa

ele está fazendo casa(s)

Talvez (5) se explique como o sujeito tendo passado a fazer casas, 'tem feito casas' 'está fazendo casas esses dias', etc. Nessa sentença também notamos a tradução pelo presente contínuo do português, com objeto direto 'casa(s)' sem artigo (top sem marcador de objeto diferenciado), sugerindo atelicidade.

(6) tir lax-ãm

3SG cair-TEL

ele caiu

(7) tir ned-ãm

3SG vir-+TEL

ele veio

(8) tir mẽr-ãm

3SG não.ter-TEL

ele não tem mais

Em (6) e (7) temos exemplos em que o mofema parece conferir perfectividade ao verbo.

Em (8) vemos o sentido de mudança de estado que - $\tilde{a} m$ adiciona à sentença com o verbo $m \tilde{e} r$ (não ter > não ter mais).

Ocorrências de -ãm no trabalho de campo de julho de 2015: 
(9) tir yok-ãm pud

3 sg nadar-TEL muito

ele já nadou muito

(10) tir yok pud-ãm

3 sg nadar muito-TEL

ele já nadou muito

Em (9) e (10) vemos que o marcador - ãm pode vir tanto sufixado ao verbo quando ao marcador de intensidade pud ('muito').

\section{(11) *tir yok pud-ãm-ẽr}

3sg nadar muito-TEL-NEG

(12) tir yok-ẽr pud-ãm

3sg nadar-NEG muito-TEL

ele não nadou muito

Em (11) e (12) vemos que a negação - err só pode se afixada diretamente ao verbo.

(13) tir yok yẽw-ãm

3 sg nadar bom-TEL

ele já nadou bem

(14) *tir yok cem-ãm

3 sg nadar ontem-TEL

(15) tir yok-ãm cem

3sg nadar-TEL ontem

ele já nadou ontem 
Nas frases (13) a (15) vemos que -ãm pode vir sufixado ao advérbio de modo yẽw, mas não ao advérbio de tempo cem. Isso porque o primeiro é parte do sintagma verbal, mas o segundo não ('nadar ontem' não é um tipo de nadar, 'nadar bem’ é).

\section{(16) rid yok-ãm rũ'}

3pl nadar-TEL-PERF2

eles todos foram nadar

(17) rid yok-ãm rũ'ẽr

3 pl nadar-TEL PERF2-NEG

eles todos não/nem todos eles foram nadar

Em (16) e (17) coocorre com o marcador rü' (chamado de perfectivo 2 por Martins mas reanalisado aqui como quantificador universal nominal) mas é traduzido como se ainda fosse o verbo 'ir', indicação de que sua gramaticalização a partir desse verbo ainda não deve estar completa.

\section{(18) yok-ãm rãm-or!}

nadar-TEL ir-IMP

vai nadar!

Em (18) vemos que o morfema é compatível com o imperativo. Isso se dá apenas se seguido do seu cognato verbal rãm (ir). Sentenças com o imperativo -or sufixado diretamente no morfema foram rejeitadas pelos falantes nativos.

(19) 'id ‘õt-ãm

$1 \mathrm{pl}$ chorar-TEL

nós já choramos/já estamos chorando

Em (19), o tempo não importa: o que interessa é que se entra no estado de 'estar chorando'.

\section{(20) 'id 'õt yũt-ãm}


1pl chorar PERF-TEL

nós já choramos

Como indicado na seção sobre yũt acima, - ãm coocorre muito frequentemente com esse aspecto, o que é mais indício de que além de ingressividade, ele é compatível com a perfectividade.

(21) * ‘id 'õt-ãm bub

1pl chorar-TEL amanhã

(22) * 'id 'õt-ãm cem

$1 \mathrm{pl}$ chorar-TEL ontem

(23) * ‘id 'õt-ãm pud yed

$1 \mathrm{pl}$ chorar-TEL muito INTS1

(24) * ‘id 'õt-ãm yor

1pl chorar-TEL hoje

Nas sentenças de (21) a (24) vemos que, com alguns advérbios de tempo e de intensidade, o morfema é agramatical. A exata causa da agramaticalidade aqui não entendida, já que, p. ex. em (15) o marcador aparece com o advérbio cem 'ontem'.

\section{(25) 'id 'õt-ãm teen}

1pl chorar-TEL agora

já estamos chorando agora

Em (25) vemos que o morfema é compatível com o advérbo 'agora', e, portanto, com o tempo presente, indicando apenas ingressividade, onde 'entramos no estado de chorar' quer dizer que 'já estamos chorando'. 
(26) rid pitaa-ãm

$1 \mathrm{pl}$ ficar-TEL

eles já ficaram

Em (26) o morfema é compatível com o verbo pitaa 'ficar', talvez conferindo ingressividade, expressa como 'eles entraram no estado de ficar'.

(27) bertâg tas-ãm

árvore torta-TEL

a árvore já está/ficou torta

A ingressividade é clara em (27) com o verbo estativo tas, embora a tradução seja a mesma vista com o perfectivo yũt usado com verbos estativos.

(28) bertâg tas-ãm yow

árvore torta-TEL PROG1

a árvore já ficou torta

Em (28) o morfema coocorre com o marcador yow, que é chamado de progressivo por Martins mas foi reanalisado aqui como 'já' ou perfeito/perfectivo (ver seção yow abaixo).

(29) cem ba'-ãm

noite fria-TEL

a noite já está/ficou fria

(30) cem kub-ãm

noite escura-TEL

a noite já está escura

\section{(31) bub cem kub-ãm}

amanhã noite escura-TEL

amanhã a noite vai estar escura 
(32) top yẽw-ãm

casa bonita-TEL

a casa já está bonita

De (29) a (31) apresentamos mais ocorrências com verbos estativos, conferindo aos predicados um sentido similar ao de perfeito (estado presente resultado de transformação no passado), um efeito praticamente indistinguível do morfema yũt.

(33) 'ãr po-ãm topyõr

$1 \mathrm{sg}$ abrir-TEL porta

eu já estou abrindo a porta

Em (33) o morfema é compatível com verbo transitivo, traduzido como presente progressivo, talvez com sentido de 'eu fui abrir a porta, já estou abrindo', remanescente de seu sentido original de 'ir'.

(34) *tir wuud 'ãr rãm-ãm

3 sg chegar 1sg ir-TEL

quando ele chegar eu já terei ido

(35) *tir câk-ãm bigid

3sg pular-TEL de-repente

ele pulou de repente

Em (34) e (35), ele é agramatical no futuro anterior e com advérbio 'de repente', respectivamente.

(36) tuแ sõm xutu-ãm

chão gota cair-TEL

já pingou uma gota no chão

(37) dâwtee 'uub-ãm

criança acordar-TEL 
a criança já está acordando

* dâwtee kogogn-ãm

criança desmaiar-TEL

a criança está desmaiando

Não ficou muito claro porque -ãm é gramatical em (36) e (37) mas não em (38); talvez a semântica original de 'ir' desse morfema fique bem com verbos como 'cair', indicando movimento, mas não com 'desmaiar', que indica cessação de movimento. A gramaticalidade com 'acordar' talvez se deva à função ingressiva atual, de entrada em estado/ mudança de estado.

(39) 'ãm wưd dâwtee peg-ãm nã

2sg chegar criança pequena-TEL FUT

quando você chegar a criança já vai estar grande

(40) 'ãm wutd dâwtee kasãm-ãm nã

2 sg chegar criança morrer-TEL FUT

quando você chegar a criança já vai ter morrido

Em (34) vimos que o morfema se mostrou agramatical com o futuro anterior, mas em (40), com o marcador de futuro nã , ele se revela gramatical.

(41) 'ãr nĩ-ãm mug

1 sg estar-TEL aqui

eu já estou aqui

Em (41) a semântica ingressiva não poderia ser mais clara - entrou-se no estado de 'estar aqui'.

(42) 'ãr reg-ãm

1 sg cansado-TEL

eu já estou cansado 
(43) bub ‘ãr reg-ãm nã

amanhã 1sg cansado-TEL FUT

amanhã já vou estar cansado

(44) teen du-ãm

agora tarde-TEL

agora já é tarde, ficou tarde

De (42) a (44) alguns exemplos com verbos estativos, indicando ingressividade ou perfectividade, inclusive no futuro.

(45) tir paar-ãm mẽenh xaat

3sg saber-TEL 1sg-poss nome

ele já sabe meu nome

(46) tir paar yũt-ãm mẽenh xaat

3sg saber PERF1-TEL 1sg-poss nome

ele já sabia meu nome

Em (45) e (46) analisamos o morfema coocorrendo com verbo cognitivo transitivo paar 'saber'. Usado sozinho em (45) ele indica ingressividade, indicada pelo uso do presente na tradução, mas ligada a yũt indica tempo passado em (46).

(47) *bub 'ãr deel wĩnh-ãm

amanhã 1 sg poder trabalhar-TEL

Em (47) o morfema é agramatical no predicado 'poder trabalhar' com o advérbio amanhã. Talvez precise do morfema de futuro nã para ser gramatical como (43).

(48) tir yok-ẽr

3sg nadar-NEG

ele não nada/não está nadando 
3sg nadar-NEG-TEL

ele já não nada, ele não nada mais

Em (48) e (49) vê-se o contraste entre o verbo negado sozinho e acrescido de -ãm, para testar o efeito da negação sobre o morfema, que parece ser de ingressivo negado - ele entrou no estado de não nadar, mas antes nadava. Efeito similar se obtém no chinês quando se adiciona o morfema de perfectivo le a uma locução verbal negada - tā bù yóuyǒng [3sg NEG nadar] 'ele não nada' > tā bù yóuyǒng le [3sg NEG nadar PERF] 'ele não nada mais, nadava, mas parou ${ }^{21}$. Curiosamente o marcador de perfectividade Dâw, yũt, não tem esse efeito ao ser negado, pois tir yokẽr yũt significa 'ele não nadou' e tir yok yũtẽr significa 'ele não terminou de nadar'.

\section{*dâwãy xub paar-ãm tir xaat}

criança lembrar-TEL 3sg nome

a mulher já se lembrou do nome dele

O morfema é agramatical em (50) com o verbo cognitivo 'lembrar-se de' e é gramatical em (51) com o verbo $r \tilde{u}^{\prime}$ (acabar, terminar), possivelmente com sentido ingressivo aqui também, de mudança de estado.

\section{(51) wéed rũ'-ãm}

comida acabar-TEL

a comida acabou

A noção de ingressividade denotada por rãm contrasta com a noção de inceptividade ou incoatividade, expressa frequentemente por tuk 'querer'. Os exemplos de (52) a (56) foram retirados de Martins, 2004, pp. 238, 239:

\footnotetext{
${ }^{21}$ No chinês isso ocorre porque nesse caso o le é uma partícula em nível sentencial, qualificando a sentença inteira como informação atualizada, similar ao aspecto perfeito presente + passado. Para a ação perfectiva negada, o chinês mandarim retira o le e usa méi(yǒu): tā méiyǒu yóuyǒng [3sg PERF.NEG nadar] 'ele não nadou'. O Dâw não possui, segundo nossos dados, um marcador de perfeito sentencial, embora $m \tilde{a}$ (seção 4.3) possa ser um candidato.
} 


\section{(52) tir tâaw}

3 sg bravo

ele é/está bravo

\section{(53) tir tâaw tuk}

$3 \mathrm{sg}$ bravo querer

ele está começando a ficar bravo

Esta noção pode ser expressa por outros meios também, como xutu 'para baixo', 'descer', com verbos que indicam perda ou redução, com sáak 'subir' com estativos como peg 'grande':

\section{(54) tir peg saak}

3sg grande subir

ele está começando a crescer

O verbo rãm também pode expressar redução de valência:

\section{(55) tir 'yew' kalaap-ũuy'}

3 sg espatifar garrafa-AFET

ele espatifou a garrafa

\section{'yãmxu' 'yew' rãm}

onça espatifar ir

a onça se espatifou, está espatifada

Ou seja, como sua versão gramaticalizada -ãm, o verbo rãm também indica entrar no estado descrito pelo verbo estativo ou ativo, neste último caso gerando uma redução de valência, porque a noção gramatical que ambos rãm e -ãm carregam, 'entrar em estado' é intransitiva, o correspondente transitivo seria 'colocar em estado'.

Finalmente, em (57) vemos que em Dâw um verbo atélico pode ser transformado em télico pela adição do adverbial mutwap yaj 'trêz vezes' sem que nenhum morfema seja necessário (embora - ãm seja gramatical nesse caso): 
ele nadou 3 vezes

E em (58) vemos que - ãm pode ser usado em verbo atélico com advérbio de quantidade vaga, o que preserva a atelicidade do predicado, ou seja, -ãm não tem qualquer relação com telicidade.

(58) tir yok-ãm putd

3 sg nadar-TEL muito

ele já nadou muito

As sentenças (57) e (58) acima foram tiradas das amostras de 2015. Concluímos que ãm tem como função principal a ingressividade (entrada em estado, transformação) e pode ser usado com verbos e nomes. Não tem função aspectual muito clara, mas tende a indicar uma ação perfectiva.

\subsubsection{Durativo xâd e pontual dâr}

O marcador xâd origina-se do verbo homônimo 'passar', que em certas construções implica um deslocamento temporal e espacial, focalizando a duração da ocorrência dos eventos. Contudo, como marcador de aspecto, o morfema difere do verbo por não marcar necessariamente deslocamento, codificando geralmente apenas a duração do evento.

(1)
'wey kasãm/ cop yet
xâd (Martins, 2004)
mucura morrer mosca estar.no.chão DUR
a mucura está morta no chão/ as moscas ficam passando em cima dela

Foi verificado por Costa (2014) que este marcador ocorre apenas com verbos intransitivos. 
O marcador de pontual deriva do verbo dâr 'passar, movimentar-se subitamente', diferenciando-se deste apenas pelo tom. O verbo abrange ações como 'engolir, mover algo subitamente'. O próprio verbo dâr sempre ocorre em conjunção com o seu cognato dâr, o que salienta a propriedade deste morfema em marcar eventos súbitos, de duração mínima, ou seja, 'pontual' no tempo.

\section{(2) 'wey dôo' rod dâr tir-ũuy' (Martins, 2004) mucura CAUS sair PONT 3SG-AFET \\ a mucura o fez sair de uma vez}

Foi descoberto também por Costa (2014) que este marcador ocorre somente com verbos transitivos. A razão das restrições distribucionais dos morfemas supracitados ainda é motivo de especulações.

Segundo Martins (2004), os aspectos pontual e durativo interagem de forma especial no idioma. O pontual indica eventos momentâneos que ocorreram em um ponto único na linha do tempo e o durativo indica eventos que ocupam um segmento da linha do tempo, i.e. eventos dotados de extensão temporal.

Mas a interação mais interessante entre esses dois marcadores de aspecto é sua utilização como indicadores de agentividade do sujeito. Ainda segundo Martins (2004), o morfema xâd indica sujeito não agente em cláusulas intransitivas, ao passo que dâr indica sujeito agente em transitivas.

Abaixo de (3) a (6), dados das amostras de 2013/2014:

$$
\begin{aligned}
& \text { wa' buy dâr mĩs-uy pox } \\
& \text { urubu jogar PONT jabuti-AFET de cima } \\
& \text { o urubu jogou o jabuti lá de cima }
\end{aligned}
$$

(4) 'a-bug mĩs bok wox xâd

nesse-aí jabuti casco espocar DUR

daí o casco do jabuti espocou 
(5)

lat rob xâd

lata furar DUR

a lata furou

(6) 'ãr rob dâr lat

1SG furar PONT lata

eu furei a lata

Observamos em (5) e (6) como um verbo de alternância causativa (rob 'furar') seleciona $x a ̂ d$ ou dâr dependendo da valência em que ocorre.

Além disso, esses dois marcadores de aspecto desempenham uma função de indicadores de direção $(x \hat{a} d=$ horizontal, $d \hat{a} r=$ vertical $)$. Verbos como p. ex. pet 'quebrar' e $c a \hat{k}$ 'pular' são seguidos de um desses morfemas como modo de indicar a direção em que o objeto afetado pelo verbo se deslocou.

\begin{tabular}{|l|l|l|}
\hline & xâd & dâr \\
\hline verbo original & passar & passar subitamente \\
\hline aspecto & durativo & pontual \\
\hline valência exigida & intransitiva & transitiva \\
\hline $\begin{array}{l}\text { direcionalidade } \\
\text { agentividade do } \\
\text { sujeito }\end{array}$ & norizontal agente & vertical \\
\hline
\end{tabular}

Tabela 14 - Resumo de características de xâd e dâr

As questões que os dados atualmente disponíveis levantam quanto a esses marcadores e suas funções são muitas.

A interrelação entre valência verbal e pontualidade/duratividade, direção em que a entidade afetada pelo verbo ocorre e agentividade nos fez levantar a hipótese de que os 
morfemas em questão possuem mais de uma função simultaneamente (morfemas portmanteau), ou mesmo que eles não sejam morfemas de aspecto em alguns casos.

De qualquer maneira, Martins considera que os marcadores de aspecto derivam de verbos, e, portanto, quando um verbo ocorre com um desses morfemas, a estrutura resultante pode ser a de um verbo complexo formado por dois verbos, ou a de um verbo acompanhado de um núcleo funcional de valência ou aspecto.

Os morfemas xâd e dâr também parecem ter função verbalizadora em Dâw (um seria criador de verbo transitivo e outro de intransitivo).

A partir de (7) temos as ocorrências dos marcadores "durativo" e "pontual" no trabalho de campo de julho de 2015 .

(7) 'ãr bâas xâd nâxpog

1 sg atravessar DUR rio

eu atravessei o rio

(8) *ã̃r bâas xâd nâxpog-ũuy’

$1 \mathrm{sg}$ atravessar DUR rio-AFET

(9) * *ãr bâas dâr nâxpog

$1 \mathrm{sg}$ atravessar PONT rio

Os exemplos de (7) a (9) são interessantes porque contradizem a tese de que xâd só ocorre com intransitivos e sujeitos não agentivos e dâr só com transitivos e sujeitos agentivos, pois em (7) xâd foi considerado gramatical com o verbo atravessar e dâr não, com sujeito potencialmente agentivo (nem sempre atravessar um rio requer agentividade), mas a presença do marcador de objeto diferenciado - $\tilde{u} u y$ ' em (8) retira a gramaticalidade da sentença. Talvez o verbo bâas não seja transitivo em Dâw, o que explica a agramaticalidade do marcador de objeto, bem como por que xâd é gramatical. 
(10) 'a bertâg 'ãr tes dâr pis

essa árvore 1sg cortar PONT pequena

a árvore que eu cortei era pequena

(11) *'a bertâg 'ãr tes xâd pis

essa árvore $1 \mathrm{sg}$ cortar DUR pequena

a árvore que eu cortei era pequena

Em (10) e (11) confirmamos a tese da interação entre os morfemas e a valência.

(12) * bertâg nõx tu dâr

árvore cair chão PONT

a árvore caiu

(13) * bertâg nõx tu xâd

árvore cair chão DUR

a árvore caiu

Em (12) e (13) vemos que ambos são agramaticais com o verbo 'cair'. Vemos que além das várias regras de ocorrência desses morfemas quanto à valência, agentividade, direção (como indicado na tabela 12 acima), ainda existe o fato de que não podem ocorrer nunca com a maioria dos verbos, por motivos que parecem em grande parte arbitrários, e em parte dependendo do fato de que tendem a ocorrer com verbos denotando eventos dotados de movimento - mesmo assim, não com nõx 'cair', que parece um candidato perfeito para ocorrer com esses morfemas. Ou talvez porque os morfemas foram colocados após o termo tz, 'chão'. Em Costa (2014, p. 92), o marcador $x a ̂ d$ ocorre como gramatical com o verbo nõx 'cair', com sujeito igualmente inanimado, 'mamão', então nesse caso pode ter sido a ordem das palavras que gerou a agramaticalidade, e não as propriedades do verbo.

(14) * bertâg kasãm dâr

árvore morrer PONT 
(15) bertâg kasãm xâd

árvore morrer DUR

$\mathrm{a}$ árvore morreu

(16) dâwxut kasãm xâdãm

homem morrer DUR-TEL

o homem está morrendo

De (14) a (16) vemos a compatibilidade de xâd com o intransitivo kasãm, morrer, ao passo que dâr é incompativel. Vemos que xâd também coocorre sufixado com -ãm, chamado por Martins de 'télico' mas reanalisado aqui como ingressivo. Morrer é entrar em um estado.

(17) * *ãr weed dâr nãk

1 sg comer PONT açaí

eu comi açaí

(18) * ‘ãr weed xâd nãk

1 sg comer DUR açaí

eu comi açaí

Em (17) e (18) vemos a incompatibilidade dos morfemas com o transitivo weed, 'comer.'

(19) tir bâ dâr nâx

3sg derramar PONT água

ele derramou água

(20) tir bâ xâd nâx

3sg derramar DUR água

ele passou derramando água 
Em (19) e (20) os morfemas se revelam ambos compatíveis com o verbo transitivo bâ, 'derramar'. Porém, o falante preferiu traduzir (20) como 'passou derramando', o que significa que nesse caso xâd está ocorrendo apenas como verbo pleno, no seu sentido original de 'passar', ao passo que dâr estaria ocorrendo em (19) plenamente gramaticalizado.

(21) tir câk xâd bigid

3sg pular DUR de.repente

ele pulou de repente

(22) * tir câk dâr bigid

3sg pular PONT de.repente

(23) tut sõm xutu xâd

chão gota cair DUR

caiu uma gota no chão

(24) * tut sõm xutu dâr

chão gota cair PONT

De (21) a (24) temos ocorrências dos morfemas de acordo com o critério da valência.

Em (21) xâd ocorre com verbo de sujeito agentivo, contudo.

(25) rod xâd-or

sair DUR-IMP

saia!

(26) * rod dâr-or

sair PONT-IMP

(27) weed dâr-or

comer PONT-IMP 
come logo!

(28) weed xâd-or

comer DUR-IMP

come passando!/ passa comendo!

Na série de (25) a (28), com o imperativo, dâr se revela agramatical com o intransitivo rod 'sair', mas ambos são gramaticais com weed 'comer', embora xâd ocorra apenas com o sentido de 'passar'.

(29) nẽem câk xâd kasmãy ked

piolho pular DUR buraco dentro

o piolho pulou dentro do buraco

(30) * nẽem câk dâr kasmãy ked

piolho pular PONT buraco dentro

Em (29) e (30) a tese de valência se confirma mais uma vez, mas não a a agentividade. Xâd ocorre com sujeito agentivo.

(31) tir xupwoc xâd

3 sg assustar DUR

ele se assustou

(32) *tir xupwoc dâr

$3 \mathrm{sg}$ assustar

Em (31) e (32) xâd é compatível com o verbo cognitivo intransitivo xupwoc 'assustarse', mas dâr não, como se espera.

\section{(33) *tir wâay'yar xâd dâwãy-ũuy'}

3sg mentor DUR mulher-AFET 
(34) *tir wâay'yar dâr dâwãy-ũuy'

3sg mentir PONT mulher-AFET

Em (33) e (34) ambos se revelam agramaticais com o verbo 'mentir'.

(35) dâwxut wĩnh xâd

homem trabalhar DUR

o homem passou trabalhando

(36) *dâwxut wĩnh dâr

homem trabalhar PONT

Em (35) e (36) ambos são agramaticais - xâd só é aceito por ocorrer como o verbo 'passar'.

(37) 'yãm ok xâd

cachorro correr DUR

o cachorro passou correndo

(38) * 'yãm ok dâr

cachorro correr PONT

(39) tir dej dâr bôol

3sg chutar PONT bola

ele chutou a bola

(40) * tir dej xâd bôol

3sg chutar DUR bola 
Em (37) a (40) mais uma vez o par confirma sua preferência de valência, mas em (37) há agentividade, embora nesse caso xâd parece ocorrer como verbo pleno 'passar' e não como operador verbal.

(41) * 'yãm yũt dâr sãan'-̃̃uy' cachorro matar PONT gato-AFET

(42) * 'yãm yũt xâd sãan'-ũuy' cachorro matar DUR gato-AFET

Em (41) e (42) ambos são incompatíveis com o verbo 'matar.'

(43) 'ãr lôok dâr lat

1 sg furar PONT lata

eu furei a lata

(44) * ‘ãr lôok xâd lat

$1 \mathrm{sg}$ furar DUR lata

(45) 'ãr lôok yũt lat

1sg furar PERF1 lata

eu furei a lata

(46) lôok xâd lat

furou DUR lata

a lata furou

(47) ‘ãr lôok dâr tuu

1 sg furar PONT chão

eu furei o chão

(48) *`ãr lôok xâd tuu 
1 sg furar DUR chão

Os dados de (43) a (48) testam os morfemas com o verbo de alternância causativa 'furar' e a regra da valência se confirma. As sentenças (45) a (48) foram elicitadas também para verificar se o verbo 'furar' pode ocorrer com outros marcadores. A sentença 'eu furei o chão' também foi considerada gramatical com os marcadores te e $y \tilde{u} t$, mas agramatical com -ãm. Com te a sentença foi traduzida como 'ainda estou furando o chão'.

(49) be lôok tuu

pau furar chão

o pau furou o chão

(50) be lôok dâr tuu

pau furar PONT chão

o pau furou o chão

(51) * be lôok yũt tuu

pau furar PERF1 chão

(52) * be lôok te tuu

pau furar PROG3 chão

As sentenças de (49) a (52) foram elicitadas para testar sujeitos não agentivos. Mostram que dâr é gramatical, mas xâd e os marcadores yũt e te são agramaticais. A ausência de marcador aspectual, em (49), também é gramatical.

(53) rid wap pitaa xâd-ẽr

3 pl todos ficar DUR-NEG

ninguém ficou 
(54) rid wap pitaa-ẽr

$3 \mathrm{pl}$ todos ficar-NEG

ninguém ficou

Em (53) e (54) o verbo intransitivo pitaa 'ficar' pode ocorrer com ou sem xâd, e o marcador de negação vem sufixado a xâd quando esse aparece.

(55) * ‘ãr ñ̃x xâd

1sg cair DUR

(56) ‘ãr nõx xutu

1 sg cair chão

eu caí

(57) * ‘ãr 'õt xâd

1 sg chorar DUR

eu chorei

Em (55) e (57) xâd é agramatical com verbos intransitivos. Não deve se tratar de exceção à regra, e sim de casos fortuitos. A sentença (56) foi produzida quando se pediu que o falante produzisse a tradução mais natural de 'eu caí', escolhendo uma estrutura sem o marcador aspecual. Contudo, em Costa (2014) o marcador xâd se revela gramatical com o verbo ‘cair' e sujeito inanimado ‘mamão' (p. 92).

(58) 'ãr câk xâd

1sg pular DUR

eu pulei

(59) ‘ãr câk xâd-ẽr

1sg pular DUR-NEG

eu não pulei 
No par afirmativo vs. negativo de (58) e (59) vemos que xâd é compatível com verbo transitivo de sujeito agentivo.

(60) yãm câk dâr cachorro pular DUR

o cachorro deu um pulo

(61) 'ãr dimdak dâr topyõr

$1 \mathrm{sg}$ fechar PONT porta

eu fechei a porta

(62) 'ãr po dâr topyõr

$1 \mathrm{sg}$ abrir PONT porta

eu abri a porta

(63) 'ãr po te topyõr

1sg abrir PROG3 porta

eu ainda estou abrindo a porta

(64) ‘ãr po-ãm topyõr

$1 \mathrm{sg}$ abrir-TEL porta

eu já estou abrindo a porta

(65) 'ãr po dâr yũt topyõr wap

1sg abrir PONT PERF1 porta todas

eu abri todas as portas

A intenção nas sentenças de (61) a (65) foi saber até que ponto verbos que ocorrem com dâr também ocorrem com outros marcadores. Vemos em (65) que o morfema coocorre inclusive com yũt. Não foi possível testar todas as opções por questão de tempo, mas pudemos verificar que geralmente os verbos que ocorrem com dâr (e com xâd) também são gramaticais com os outros morfemas.

(65) *aãr po-ẽr dâr topyõr 
1sg abrir-NEG PONT porta

(66) 'ãr po dârẽr topyõr

$1 \mathrm{sg}$ abrir PONT-NEG porta

eu não abri a porta

Em (65) e (66) vemos que o morfema de negação -ẽr só pode ser afixado no marcador, e não no verbo.

(67) ñ̃' wât 'id ãa ka' xâd xub (Narrativas)

outro dia ipl dormir deitado DUR com.fome

às vezes nós dormíamos com fome

(68) dôo' xâd 'weer uy (Narrativas)

mover DUR HAB2 porque

porque eles levavam tudo

(69) aag 'ãr rãan têen yor 'ãr rãan xâd (Narrativas)

esse.aí 1sg contar agora hoje 1sg contar DUR

isso aí eu estou contando agora

(70) abug tir çop yêt xâd (Narrativas)

aí 3sg bicho deitar.no.chão DUR

aí ele estava deitado cheio de bicho

De (67) a (70) vemos que xâd também é compatível com os morfemas imperfectivo/ habitual/ durativo, mas como as anteriores acima deixam claro, ocorre também com predicados perfectivos, sendo, portanto, neutro quanto à perfectividade.

Assim, fica aparente que os morfemas, além de dependerem da valência verbal, selecionam apenas verbos que denotam ações de movimento brusco ou súbito, como furar, quebrar, abrir, pular, chutar, além de verbos semanticamente relacionados ao 
significado original desses morfemas (passar), como atravessar. A tese da correlação entre os dois morfemas e a agentividade do sujeito não fica bem substanciada.

A aparente arbitrariedade do uso desses morfemas, que se combinam com alguns verbos mas não com outros aparentemente sem critério, está longe de ser sem paralelos na linguística, por exemplo no inglês o morfema verbal up marca telicidade em verbos como drink, burn e eat (drink up, eat up) mas não em verbos semanticamente relacionados, como swallow e smoke, e inúmeros outros exemplos em inglês e outros idiomas em que certos morfemas ou afixos ocorrem ou não com certas raízes por razões arbitrárias, obscuras ou apenas petrificadas no léxico do idioma.

\subsubsection{Iterativo beey (de novo)}

Deriva do verbo bey 'repetir', com o qual coocorre frequentemente, e para Martins 'codifica eventos repetitivos'.
(1) nũx 'ãay 'ãx paar beey
curupira fêmea pedir saber ITER
a mulher do curupira perguntou de novo

Esse morfema parece sempre ser satisfatoriamente traduzido pelo advérbio 'de novo', o que talvez indique que uma descrição mais adequada para ele seria 'repetitivo', pois é usado mesmo que a ação se repita apenas uma vez, ao passo que 'iterativo' sugere várias repetições.
(2) tir nĩ beey
3SG estar ITER
ele está de volta

(3) tir mẽr beey 
3SG não-estar ITER

ele não está mais

Em (2) e (3) vemos uma interação curiosa entre beey e verbos de estado, em que ele parece sinalizar uma mudança de estado, ou uma inversão. Isso parece derivar naturalmente da semântica de beey como 'de novo’: ele está de novo', ou seja, 'ele voltou, está de volta; e 'ele não está de novo', ou seja, 'mais uma vez ele foi embora'.

Abaixo, apresentamos as amostras do trabalho de campo de julho de 2015.

(4) dâwtee 'õt beey

criança chorar ITER

a criança está chorando de novo

(5) cem kub beey

noite escura ITER

a noite vai ficar escura de novo

(6) cem kub beey-ẽr

noite escura ITER-NEG

a noite não vai ficar escura de novo

(7) cem kub-ẽr beey

noite escura-NEG ITER

a noite ficou clara de novo

(8) 'ãr po dâr beey topyõr-ũuy'

$1 \mathrm{sg}$ abrir PONT ITER porta-AFET

eu abri a porta de novo

(9) ‘ãr po dâr beeyẽr topyõr-ũuy'

1 sg abrir PONT ITER-NEG porta-AFET

eu não abri a porta de novo 
(10) top yẽw beey

casa bonita ITER

a casa ficou bonita de novo

Em (11) e (12) vemos que o morfema negativo pode ser sufixado ao morfema beey, indicando que o evento não se deu novamente. A negação no verbo estativo $k u b$ em (11) implica que a noite vai ficar clara de novo, como vemos em (7) acima.

(11) cem kub beey-ẽr

noite escura ITER-NEG

a noite não vai ficar escura de novo

(12) 'ãr po dâr beey-ẽr topyõr-ũũy'

$1 \mathrm{sg}$ abrir PONT ITER porta-AFET

eu não abri a porta de novo

Nas amostras das Narrativas, verificamos inclusive que beey nem precisa ficar restrito à posição pós-verbal, como os demais morfemas analisados, podendo ocorrer antes do verbo em (14).

(13) 'abug 'yãmxu' beey yâa dôo beey xuwêel yar

aí onça ITER voltar levar ITER coelho buscar

aí a onça voltou para pegar o coelho

(14) 'abug ray yãmxu' beey nẽd xuwêel pej

aí como.é onça ITER vir coelho perto

aí a onça veio de novo, perto do coelho

O morfema ocorre até em sentenças sem verbo:

(15) 'id sun beey

$1 \mathrm{pl} \mathrm{COLETIVO} \mathrm{ITER}$

nós também, outra vez 
Ou seja, parece ser meramente um advérbio comum do idioma, não confinado ao sintagma verbal, significando meramente 'de novo', 'novamente'.

\subsubsection{Habitual 1 tâg \& habitual 2 'weer}

O habitual 1 tem como origem o verbo tâg 'conhecer'. Segundo Martins, os eventos marcados com tâg são tipicamente entendidos como eventos que persistem no tempo, que ocorrem frequentemente, com habitualidade e do mesmo modo. A relação semântica deriva do fato de que o evento que se repete com frequência é algo conhecido, um hábito.

Segundo Martins, o habitual 2 'weer não deriva de verbo cognato correspondente. Indica a frequência do evento, referenciando uma prática regular e frequente, ao contrário do habitual 1 tâg, esse é compatível com o tempo futuro.

Provavelmente 'weer é um advérbio significado algo muito próximo de 'sempre' nas línguas europeias, sendo, portanto, um quantificador verbal. Isso explica sua compatibilidade com o tempo futuro, pois ao contrário de tâg (que significa 'conhecer' como verbo), o marcador 'weer não implica em hábito derivado de experiência ou aprendizado.

Segundo Comrie (1976) e Frawley (1992), o aspecto habitual codifica um evento de quantificação indefinida, não associado a uma ocorrência específica, e sim com um período completo, do qual o evento ou estado é uma característica.
(1) dâw waar dâr sãr rid-ũuy rid sãr tâg rẽd-dũ'
3SG velho PLURALIZADOR ensinar 3PL-AFET 3PL ensinar HAB1 ser-igual os velhos os ensinam como sempre ensinaram

Abaixo seguem dados das amostras relevantes de 2014: 
(2) [ãr pis ten] 'ar ãa tâg 8 horas

[1SG pequena quando] 1SG dormir HAB1 8 horas

quando eu era pequena, eu costumava dormir às oito horas

(3) [ãr xãn xid] 'ar ãa *tâg çem tuut

[1SG velha quando] $1 \mathrm{SG}$ dormir HAB1 meia noite

quando eu for velho, vou costumar dormir à meia-noite

(4) dâwtee yũt tâg naap

criança matar HAB1 barata

a criança costumava matar barata

(5) [dâwtee tir xãn xid] yũt *tâg naap

[criança 3SD velho quando] matar HAB1 barata

a criança vai costumar a matar barata quando ela for adulta

Em (3) e (5) vemos que o morfema tâg não é compatível com o futuro. Isso indica que também este morfema é portmanteau e indica além de aspecto, tempo (não-futuro) ou modo (realis). Essa incompatibilidade provavelmente é herdada da origem lexical do morfema como o verbo 'conhecer', ou seja, expressa um hábito adquirido por experiência passada, conhecimento já adquirido.

O falante tem que recorrer ao morfema 'habitual 2' (weer) para expressar uma ação habitual futura.

(6) 'ãr ãa' tâg $10 \mathrm{~h}$

1SG dormir HAB1 10h

eu costumo dormir às $10 \mathrm{~h}$

Sentenças relevantes das amostras tomadas em 2013/2014:

(7) 'ar ãa 'weer 10 horas

1sg dormir HAB2 10 horas

eu costumo dormir às 10 horas 
(8) 'ãr pis ten 'ar ãa 'weer çem tuut

1sg velho quando $1 \mathrm{sg}$ dormir HAB2 noite meia

quando eu for velho, vou costumar dormir à meia-noite

(9) dâwtee tir rân xid yũt 'weer naap

criança 3SG velho quando matar HAB2 barata

a criança vai costumar a matar barata quando ela for adulta

(10) 'ãr ãa' 'weer 10 horas

1SG dormir HAB2 10 horas

eu costumo dormir às 10 horas

(11) dâwtee yũt 'weer naap

criança matar HA2 barata

a criança custuma matar barata

A partir de (12) temos as amostras do trabalho de campo de julho de 2015

(12) cem kub tâg

noite escura HAB1

as noites às vezes são escuras

(13) * top yẽw tâg

casa bonita/boa HAB1

(14) ãr bâs tâg nâxpog

1sg atravessar HAB1 rio

eu sempre atravesso o rio

(15) * bub 'ãr bâs tâg nâxpog

amanhã 1sg atravesar HAB1 rio

eu sempre atravessarei o rio 
(16) dâwxut âg tâg nâx

homem beber HAB1 água

o homem sempre bebe água

(17) dâwxut âg 'weer nâx

homem beber HAB2 água

o homem sempre bebe água

(18) 'ãr weed tâg nãk

1sg comer HAB1 açaí

eu já experimentei açaí

(19) tir bax tâg mug

3 sg aparecer HAB1 aqui

ele já apareceu aqui

(20) * tü sõm xutu tâg

gota cair chão HAB1

(21) * tut sõm xutu 'weer

gota cair chão HAB2

A agramaticalidade de (20) poderia ser explicada pela falta de agentividade de 'gota', ou talvez por sua inanimacidade, mas a agramaticalidade de (21) não se deixa explicar facilmente.

(22) tir nê 'weer tâg 'a

3sg fazer HAB2 HAB1 isso

ele sempre faz isso

(23) tir yok 'weer tâg mug 
3sg nadar HAB2 HAB2 aqui

ele sempre nada aqui

(24) tir âg tâg nâx

3sg beber HAB1 água

ele sempre bebe água

(25) tir âg 'weer nâx

3sg beber HAB2 água

ele sempre bebe água

(26) tir âg 'weer tâg nâx

3 sg beber HAB2 HAB1 água

ele sempre bebe água

(27) * tir âg tâg 'weer nâx

3 sg beber HAB1 HAB2 água

ele sempre bebe água

De (22) a (27) testamos a gramaticalidade de ambos um com o outro nas duas ordens possíveis. Vemos que a ordem 'weer + tâg é gramatical, mas tâg + 'weer não.

(28) 'ãr weed 'weer cem

1sg comer HAB2 noite

eu sempre como à noite

(29) 'ãr weed tâg cem

1sg comer HAB1 noite

sempre como à noite

Em (28) e (29) os morfemas são compatíveis com habitualidade presente.

(30) 'ãr rân 'ãr weed 'weer cem

1sg velho 1sg comer $\mathrm{HAB} 2$ noite 
quando eu for velho sempre vou comer à noite

(31) * ‘ãr rân ‘ãr weed tâg cem

1sg velho 1sg comer HAB2 noite

quando eu for velho sempre vou comer à noite

Em (30) e (31) mas uma vez vemos que 'weer é compatível com o futuro, mas tâg não.

(32) ' 'ãr weyteen 'ãr weed 'weer cem

1sg pequeno $1 \mathrm{sg}$ comer HAB2 noite

quando eu era pequeno eu comia à noite

(33) 'ãr weyteen 'ãr weed tâg cem

1sg pequeno 1sg comer HAB1 noite

quando eu era pequeno eu comia à noite

Em (32) e (33) ambos são compatíveis com habitualidade no passado remoto.

(34) tir wâay'yar tâg dâwã-ũuy'

3sg mentir HAB1 mulher.AFET

ele sempre mente pra mulher

(35) tir wâay'yar 'weer dâwãy-ũuy'

3sg mentir HAB2 mulher.AFET

ele sempre mente pra mulher

Em (34) e (35) ambos são compatíveis com o verbo ativo 'mentir'.

(36) * dâwtee 'õt tâg

criança chorar HAB 1

a criança sempre chora

(37) dâwtee 'õt 'weer

criança chorar HAB2 
criança sempre chora

Em (36), tâg é agramatical com 'chorar', talvez por implicar 'conhecer', ou seja, algum grau de agentividade, volição, ao passo que chorar, especialmente quando se trata de criança, é ação involuntária, que não foi aprendida. Com 'weer em (37) temos uma sentença perfeitamente gramatical, pois 'weer, ao que tudo indica, significa meramente 'sempre'.

\section{(38) dâwxut wĩnh tâg}

homem trabalhar HAB1

o homem sempre está trabalhando

(39) dâwxut wĩnh 'weer

homem trabalhar HAB2

o homem sempre está trabalhando

Já com o verbo ativo winh 'trabalhar', algo que se aprende e só se com volição e agentividade, tâg é gramatical.

(40) 'ãr pis tẽn 'ãr âg tâg lêc

1sg pequeno CONJ 1sg beber HAB1 leite

quando eu era pequeno eu sempre bebia leite

(41) 'ãr pis tẽn 'ãr âg 'weer lêc

1sg pequeno CONJ 1sg beber HAB2 leite

quando eu era pequeno eu sempre bebia leite

(42) * ‘ãr pis tẽn 'ãr âg 'weer tâg lêc

1sg pequeno CONJ 1sg beber HAB2 HAB1 leite

quando eu era pequeno eu sempre bebia leite

Ambos são compatíveis com o verbo beber, volitivo e agentivo, em (40) e (41) mas em coocorrência na ordem 'weer + tâg, ao contrário do que vimos em (22), (23) e (26) acima, a combinação foi rejeitada pelo falante. 
(43) rid cik 'weer

3pl sujo HAB2

eles sempre estão sujos

(44) * rid cik tâg

3pl sujo HAB1

(45) * tir peg tâg

3 sg grande HAB1

(46) tir peg 'weer

3 sg grande HAB2

ele sempre cresce

(47) tir pis 'weer

3 sg pequeno HAB2

ele sempre é pequeno

(48) tir wum 'weer

$3 \mathrm{sg}$ forte HAB2

ele sempre é forte

De (46) a (48), vemos 'weer com estativos. A tradução é o que se espera se 'weer significar 'sempre'.

(49) 'ãr rẽk 'weer tir-ũuy'

1sg gostar HAB2 3sg-AFET

eu sempre vou gostar dela

(50) 'ãr rẽk tâg tir-ũuy'

$1 \mathrm{sg}$ gostar HAB2 $3 \mathrm{sg}$ 
eu já gostei dela

Em (49) e (50) temos um fenômeno interessante: uma sentença com o verbo cognitivo rẽk 'gostar' passa ao futuro com 'weer, mas com tâg significa passado. Talvez (50) signifique algo como 'eu conheci e gostei dela', e não 'eu uma dia gostei dela, e não mais' como a tradução fornecida pode sugerir.

(51) tir yar yâ 'weer tir wéed tóc tir 'ãm -ũuy' 3SG trazer voltar HABII 3SG comida pedaço 3SG esposa -AFET ele sempre trazia resto de comida para a mulher dele.

(52) bertâg pis weer

árvore pequena $\mathrm{HAB} 2$

a árvore sempre é pequena

(53) bertâg pis weer-ẽr árvore pequena HAB2-NEG

a árvore nunca é pequena

(54) cem kub weer

noite escura HAB2

a noite sempre é escura

cem kub weer-ẽr

noite escura HAB2-NEG

a noite nunca fica clara

De (52) a (55) vemos o efeito da negação sufixada a 'weer, que passa asignificar 'nunca'.

Vemos que, sendo equivalente a 'sempre', 'weer é um quantificador que ocorre no sintagma verbal, como rũ', mas, ao contrário de rú', ele se refere ao verbo e à sua extensão temporal, e não a seus argumentos, como faz rũ '. 
Já o morfema tâg parece precisar em certos casos que haja alguma volição ou consciência por parte do sujeito, que desenvolve a ação do verbo por ter adquirido conhecimento e experiência, ao passo que 'weer é um advérbio de tempo.

\subsubsection{Progressivo 1 yow (perfectivo súbito/direto)}

$\mathrm{Na}$ descrição de Martins, este morfema deriva do verbo equativo yow 'ser reto/ atalhar $^{22}$, e indica que o evento ocorreu de forma ininterrupta e com agilidade, mas sem destacar a sua duração. Não fica bem substanciada a escolha de Martins da designação "progressivo".

(1) tir xu yow xo ked med rid (Martins, 2004)

3SG descer PROGI canoa em rio abaixo DIRECIONAL

ele desceu de canoa direto, lá pra baixo.

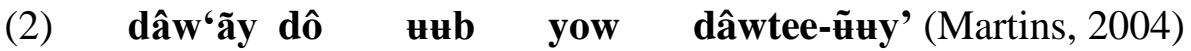

mulher CAUS acordar PROG1 criança-AFET

a mulher já está acordando a criança

Note que em vários exemplos das amostras elicitadas em 2014 o falante nativo parece inserir um "já” na frase sem que haja realmente uma palavra equivalente.

(3) dâwtee uub yow (Martins, 2004)

criança acordar PROG1

a criança já está acordando / acordou

\footnotetext{
${ }^{22}$ É curioso notar que em Alemão o adjetivo e advérbio gerade (reto, direto, já) é usado para indicar progressividade no idioma informal, suprindo a falta de meio flexional de progressivo nesse idioma.
} 
A sentença (3), tirada de Martins, é apresentada com as duas traduções, 'está acordando' e 'acordou'. Nas amostras recentes os falantes consideram gramatical apenas a tradução '(já) acordou'.

(4) dâw'ãy do wĩnh yow dâwtee-ũuy mulher CAUS trabalhar PROG1 criança-AFET

A mãe já fez a criança trabalhar/deixou a criança trabalhando (já foi)

(5) dâw'ãy do $\operatorname{kog}^{\text {`ogn }}$ yow dâwtee

mulher CAUS desmaiar PROG1 criança

a mulher deixou a criança desmaiando

(6) dâwtee $\operatorname{kog}^{6} \operatorname{ogn}$ yow

criança desmaiar PROG1

a criança está desmaiando

(7) dâwtee yũt yow naap

criança matar PROG1 barata

a criança já matou a barata

Em (6) a tradução é dada no progressivo, mas falantes atuais dariam uma tradução no passado com 'já'. Em (7) a tradução implica perfectividade no passado, quando se esperaria da denominação de Martins uma tradução "a criança está/estava matando a barata".

É de conhecimento de linguistas que muitas vezes falantes de idiomas isolantes com partículas verbais aspecto-modais intradutíveis em idiomas indoeuropeus tendem a eleger algum advérbio do idioma alvo ocidental como padrão para traduzir suas partículas literalmente. Em Matthews \& Yip (2009) lemos que "Chinese-English bilingual children seem to transfer Cantonese aspect markers into their English. The English adverb 'already now' seems modeled after Cantonese verb + zo laa, where 'already' expresses perfective meaning and 'now' current relevance" (tradução livre: 'crianças bilíngues em cantonês e inglês parecem transferir os marcadores de aspecto do Cantonês para o inglês. O advérbio inglês already now [já agora] parece se modelar 
com base na construção cantonesa verbo + zo laa, em que 'já' expressa perfectividade e 'agora' expressa relevância atual').

Contudo, o advérbio 'já' e seus equivalentes nas diversas línguas europeias e outras, bem como o seu inverso 'ainda', não são marcadores de perfectividade ou imperfectividade. É possível usar 'já' com qualquer aspecto, inclusive os mais claramente imperfectivos: 'eu já estou indo, eu já irei amanhã, eu já estava comendo, quando era pequeno já comia carne', etc. Assim como 'ainda', que pode ser usado com os predicados mais perfectivos possíveis: 'eu ainda comi outro pedaço, eu ainda terei feito mais uma coisa, eu ainda terminei de ver o filme', etc. Os advérbios 'já' e 'ainda' são advérbios de tempo com um elemento cognitivo relativo às expectativas do falante, pois denotam, respectivamente, ação ou estado iniciado antes do esperado e ação ou estado prolongado após o tempo esperado.

\section{(8) dâw'ãy ya' yow taax \\ mulher assar PROG1 anta \\ a mulher está assando a anta (já assou)}

Em (8) novamente o falante insere uma outra tradução, perfectiva com 'já', imediatamente após a primeira, colocada aqui entre parênteses. Inicialmente suspeitamos que isso provavelmente se devesse à interação entre tempo e aspecto com o marcador yow - que poderia marcar progressividade ou imperfectividade no tempo presente, mas no passado inverteria para aspecto perfectivo. As amostras de 2015, contudo, indicaram bastante claramente que o marcador indica apenas perfectividade, mesmo quando no presente.

(9) dâw 'ãy ya' yow taax

mulher assar PROG1 anta

a mulher já assou a anta

(10) dâwtee kâs yow dâw'ãy

criança morder PROG1 mulher

a criança já mordeu a mulher 
(11) dâwtee 'ãa yow

criança dormir PROG1

a criança já dormiu

(12) dâwtee yũt yow naap

criança matar PROG1 barata

a criança já matou a barata

(13) dâwtee kâs yow dâw'ãy

mulher morder PROG1 mulher

a criança já mordeu a mulher

(14) dâwtee yũt yow naap

criança matar PROG1 barata

a criança já matou a barata

Vê-se de (9) a (14) que a tradução dos verbos com yow tende a indicar uma perfectividade no tempo passado com verbos télicos ou atélicos, em contraste com a progressividade (em qualquer tempo) que se esperaria a partir da denominação dada em Martins (2004).

A partir de (15) analisamos as amostras do trabalho de campo de 2015:

(15) ‘ãr paar yow

1sg saber PROG1

eu já sei

(16) 'ãr paar-ẽr rãm yow

1sg saber-NEG ir PROG1

eu não sei mais

Em (15) e. E vemos também que com o verbo cognitivo 'saber' o efeito é um estado já atingido, aspecto perfeito, ou seja, como o marcador de perfectivo yũt, com verbos estativos yow deixa de significar ação completa no passado para designar estado 
presente derivado de transformação no passado, o 'perfeito' (passado mais presente) descrito em Comrie (1976). Em (16) vemos também que no negativo que o morfema precisa da companhia do verbo rãm 'ir' para aparecer na sentença. Como veremos adiante a esmagadora maioria das ocorrências de yow nas Narrativas e em Martins (2004) é com esse verbo, que também possui função ingressiva. Veremos adiante que o morfema yow parece ser agramatical com verbo negado.

(17) 'ãr wây yow tir-ũuy

1sg ver PROG1 3sg-AFET

eu já vi ele

(18) * ‘ãr wây-ẽr yow tir-ũuy

1sg ver-NEG PROG1 3sg-AFET

(19) ‘ãr weed yow dep

1sg comer PROG1 carne

eu já comi carne

(20) * ‘ãr weed-ẽr yow dep

1 sg comer-NEG

Com o verbo 'ver' e 'comer' a tradução mais natural dada, como na maioria dos casos, é de passado com advérbio 'já'. Não ficou claro porque a negação é agramatical nesses casos, mas notamos que negar uma sentença cujo verbo é acompanhado pelo advérbio ‘já' também soa estranho nas línguas europeias no afirmativo ('eu já não comi carne').

(21) * bub ‘ãr weed yow dep

amanhã 1sg comer PROG1 carne

No futuro yow é agramatical, ao menos com tradução de futuro simples. 
(22) 'ãr weed yed yow tir dep

1sg comer INTS1 PROGR 3sg carne

eu já comi a carne dele

Com o verbo 'comer' ativo transitivo, temos a tradução de yow como passado perfeito, coocorrendo com o intensivo 1 yed, um advérbio de intensidade.

(23) ‘ãr rẽk yow sibe

1sg gostar PROG1 xibé

eu estou gostando de xibé

(24) teen ‘ãr âg rẽk yow sibeũuy

agora 1sg beber gostar PROG1 xibé.AFET

agora eu gosto de tomar xibé

(25) teen 'ãr tuk yow réw rãap

agora 1sg querer PROG1 muitos peixes

agora eu quero muitos peixes

De (23) a (25) com verbo cognitivo rẽk e com o modal tuk indica presente, ou estado atingido. Ou seja, embora a tradução seja presente progressivo em português, o fato de o verbo ser cognitivo implica semanticamente um estado cognitivo atingido.

(26) tir yũt yow rãap

3sg matar PROG1 peixe

ele já matou peixe

(27) *teen tir yũt yow rãap

agora 3sg matar PROG1 peixe 
Em (26) e (27) vemos que forçar uma sentença com yow no presente, com o advérbio teen 'agora' leva à agramaticalidade, e não à tradução "agora ela (já) está matando o peixe" que seria esperado se yow tivesse propriedades progressivas.

\section{(28) be tas rãm yow \\ pau torto ir PROG1 \\ o pau já ficou torto}

Com estativo + auxiliar ingressivo rãm (ir) o morfema é gramatical e indica entrada no estado, ou estado atingido, como com os verbos cognitivos, ou seja, marca perfectividade aqui também.

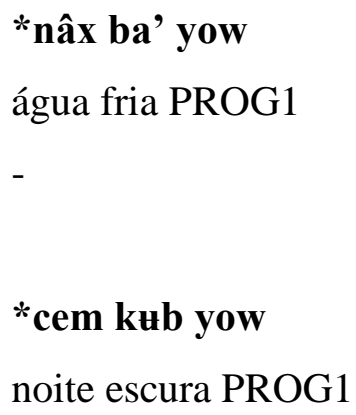

Em (29) temos dados que indicam uma possível agramaticalidade com certos verbos estativos.

(31) paas bế' yow

pedra dura PROG1

a pedra já ficou dura

Em (31) o falante indica que é gramatical com este estativo, indicando estado atingido.

cem ba' yow

noite fria PROG1

a noite ficou fria

\section{(33) top yẽw yow}


noite PROG1

a casa já ficou bonita

Com os verbos estativos de (31) e (32), yow é gramatical. Não foi possível determinar porque yow é gramatical com $b a$ ' 'frio' em (32) mas não em (29).

\section{(34) bub 'ãr bâs yow nâxpog \\ amanhã 1sg atravessar PROG1 rio \\ amanhã já vou ter atravessado o rio}

O morfema é gramatical no futuro anterior 'já terei atravessado', ou seja, passado do tempo de referência futuro.

(35) tir wutd ‘ãr rãm yow nã

3sg chegar 1sg ir PROG1 FUT

quando ele chegar eu já terei ido

Em (35) outro futuro anterior com yow, que é gramatical.

\section{(36) bub 'ãr rãm yow \\ amanhã 1sg ir PROG1 \\ amanhã eu estou indo}

Em (36) temos uma instância de aparente progressividade com yow, notadamente no presente do futuro, tempo em que o marcador parece ser agramatical. A tradução progressiva pode ter sido opcional. Talvez a tradução mais natural seria 'já terei ido’ ou 'estarei indo', no futuro do futuro. Observem que yow tende a ocorrer muito com o verbo rãm 'ir' e talvez nesse caso ainda signifique 'reto, direto'.

* bub ‘ãr weed yow

amanhã 1sg comer PROG2 
O morfema é agramatical em (37) com verbo ativo 'comer' no futuro. Deve ser agramatical com verbos sem semântica de movimento.

(38) tut sõm xutu yow

chão gota cair PROG1

já caiu uma gota no chão

Em (38) ele ocorre com sentido perfectivo passado, com verbo de movimento.

(39) * bub ‘ãr pilsij wĩnh yow

amanhã 1 sg precisar trabalha PROG1

Em (39) o morfema é agramatical no futuro com 'precisar trabalhar'. Talvez no futuro só seja gramatical se for forçada a intepretação como futuro anterior (terei trabalhado).

(40) * tir xupwoc yow

3sg assustar PROG1

ele se assustou

O morfema fica agramatical em (40) com o verbo assustar-se e em (41) com o verbo 'comer', mesmo sem advérbio temporal, talvez por serem verbos sem semântica de movimento.

(41) * tir weed yow

3sg comer PROG1

(42) * dâwtee 'õt yow wâat wap

criança chorar PROG1 dia todo 
Yow fica agramatical em (42) com advérbio indicador de continuidade, tempo prolongado 'o dia todo'. Isso indica perfectividade.

(43) * dâwtee 'õt yow pud yedê'

criança chorar PROG1 muito INTS-PASS

O morfema é agramatical em (43) com o sufixo de tempo passado - $\hat{e} e$ ' adicionado ao adverbial pud yed (muito). Mas talvez a fonte de agramaticalidade em (42) e (43) seja o verbo õt, que não é de movimento.

(44) * ‘ãr pis tẽn 'ãr âg yow lêc

1sg pequeno CONJ 1sg beber PROG1 leite

Em (44), mais uma vez, yow se revela agramatical com noções durativas.

(45) dâwãy xubpaar yow tir xaat

criança lembrar PROG1 3sg nome

a mulher já se lembrou do nome dele

Em (45) temos uma tradução no pretérito perfeito com o cognitivo 'lembrar-se', mas o sentido pode muito bem ser o de estado presente resultado de ação no passado, 'eu me lembrei' signfica que estou com a memória agora na cabeça, aliás vemos aqui como em português o verbo cognitivo no pretérito perfeito tem significado de estado presente resultado de evento passado, como 'saber', que no pretérito perfeito 'soube' não significa ter sabido e não saber mais, ao contrário, significa não ter sabido e saber agora. Assim vemos a importância de distinguirmos entre verbos ativos e não ativos (estativos e cognitivos) quando estudamos o aspecto.

(46) dâwãy dôo' uub yow dâwteeũuy'

mulher CAUS acordar PROG1 criança.AFET 
a mulher já acordou a criança

Em (46), temos a gramaticalidade de yow uma sentença perfectiva com a construção causativa.

(47) * tir cik yow

3sg sujo PROG1

ela já se sujou

Mais uma das várias instâncias em que o verbo estativo cik é agramatical com marcador de aspecto aparece em (47). Deve ser algo inerente a este item lexical. Talvez ele seja realmente um nome, significando 'sujeira', usado atributivamente para significar 'sujo'.

(48) tir pis yow

3sg pequeno PROG1

ele ficou pequena

(49) tir peg yow

3sg pequeno PROG1

ele ficou grande

O uso de yow revela-se gramatical em (48) e (49), com sentido de aspecto perfeito, com 'estar grande' e 'estar pequeno'.

(50) bub rid weed rũ' yow

amanhã 3pl comer PERF2 PROG1

amanhã eles vão comer/ter comido tudo

(51) * bub rid âg yow rũ' nâx

amanhã 3pl beber PROG1 PERF2 água

amanhã eles vão ter bebido água 
Em (50) temos o morfema em uso no perfectivo futuro coocorrendo com o marcador $r \tilde{u}$ '. Agramatical em (51) no futuro precedendo o marcador $r \tilde{u}$ '. Provavelmente o fator de agramaticalidade neste caso é a ordem dos morfemas.

\section{(52) tir need yow tir rãm yow}

3sg vir PROG1 3sg ir PROG1

ele veio (mas) ele já foi embora

Em (52) a gramaticalidade da sentença indica que yow pode ser perfectivo mas não é perfeito (passado com presente), pois a segunda frase cancela e inverte a primeira parte, a ação de vir não é mais presente.

A partir de (53) abaixo, analisaremos exemplos retirados das Narrativas.

O morfema funcional yow aparece bastante nas Narrativas, na esmagadora maioria das vezes acompanhando o verbo rãm 'ir' e sendo traduzido pelo pretérito perfeito 'fui, foi fomos (embora)'. Ocorre uma vez com yũt (usado como verbo 'matar') e outra com kasãm 'morrer'. Uma pesquisa na Gramática de Martins (2004) também revelou que o morfema yow praticamente só ocorre com o verbo rãm e alguns outros de movimento, como $x \boldsymbol{t}$ 'descer', $x \boldsymbol{t} t \boldsymbol{t}$ 'cair' $x a \hat{j} \hat{a}$ 'entrar' totalizando dezenas de vezes, bem como duas vezes com kasãm 'morrer', traduzido em todos os casos no pretérito perfeito, às vezes com expressões como 'reto, direto, bruscamente, sem demorar, de repente'.

Essa coocorrência estrita com rãm e verbos de movimento parece redefinir nossa pesquisa e nossos resultados, já que o uso de yow com outros verbos, embora julgado gramatical pelos falantes em muitos casos vistos acima, pode ser forçado e pouco natural, com base na ocorrência de yow nas Narrativas e em Martins (2004). Assim sendo definimos yow como essencialmente um advérbio direcional significando 'reto' ou 'direto', ou 'abruptamente', que justo por esses significados de ação rápida e súbita tende e designar ações perfectivas ou pontuais ligadas a movimento e deslocamento, e excepcionalmente, a morte, vista como uma passagem, movimento. Mesmo assim, ele ocorre somente imediatamente após o verbo, e não em posições iniciais ou finais na sentença, portanto parecendo estar confinado ao slot dos morfemas funcionais do Dâw. 
Nas amostras das Narrativas abaixo, por razões práticas, ao invés de fornecermos as glosas completas, optamos, devido ao comprimento excessivo das sentenças, por apenas sublinhar as partes correspondentes nos originais e nas traduções, para evidenciar a aspectualidade dos verbos.

(53) bug rid xuH yow rid rãm yow bug nôox wôob dôo' xoo ked bug rid rãm yow abug yãm xu' nũr wôob wutd xoo ked

aí eles desceram, eles foram embora, aí entraram na canoa, aí eles foram embora, aí a cabeça da onça estava na canoa

(54) rõt rãm ka' mẽenh dee'e' nãa rõt nĩi mẽenh dee'e' nãa abug mĩis rãm yow taax çutum ked

"minha dona está muito longe, minha dona está muito longe daqui", aí o jabuti

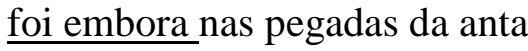

(55) Xu' tâg nãa ti' nẽp tâg nãaẽr xu' tâg nãa mãr rẽd çuuk rãm rũ' xu' tâg ridi' nãa mãr bug tir rãm yow mãr

"não era piúm", ela falou, "(por causa) de outra coisa eles estão se coçando", aí a mulher dele foi embora

(56) Abug xôod rid tôx mẽed rid tôx nĩi aa' tii ãay bug tir rãm yow mãr aí a mulher estava fazendo barulho lá emcima, depois lá embaixo, aí depois ela foi embora

(57) bug tir laayẽr bug tir yâa yow mãr ele não pescou mais... aí, ele voltou.

(58) abug tir nũp rãm puud xaay rãm yow aí, ele sumiu na mata e foi embora

(59) yũt yêd yow dâw mẽenh tugũuyũ' yũt yêd yow dâw mẽenh tugũuy'ũ' tir nãa xaa mãr tir õot tir õot mãay 
"dâw já matou meu marido! dâw matou meu marido! mataram meu marido! dâw matou meu marido!", ela estava falando e chorando. chorou muito

\section{(60) kasãm yow}

morrer PROG1

Já morreu.

Fica difícil estabelecer o real uso de yow. Uma primeira hipótese era de que se trata de mais um marcador de perfectividade, ao lado de yüt. Afinal, ele é incompatível com advérbios durativos, como 'todo dia', e (52) acima desmonta a hipótese de perfeito. A tradução como advérbio 'já' é tentadora, mas deve se tratar de um vício de tradução por parte dos falantes, como exemplificado no caso dos falantes bilíngues de inglês e cantonês descrito nesta seção, acima.

Uma sentença similar à (60) ocorre em Martins, (2004, p. 302), tir kasãm yow, e a tradução dada é 'ele morreu subitamente', em contraste com o verbo kasãm com o marcador $y \tilde{u} t$, em que a tradução tende a ocorrer no tempo pretérito perfeito, um simples 'ele morreu'. Ou seja, pode ser que a função de yow seja marcar uma perfectividade mais súbita, inesperada ou brusca, talvez pontualidade, mas quase só com verbos de movimento e deslocamento, especialmente rãm, que parece concentrar mais de $90 \%$ das ocorrências de yow nas narrativas e na gramática de Martins.

\subsubsection{Progressivo $2 \mathrm{ka}^{\prime}$}

É homônimo com o verbo 'estar deitado em rede' (Martins 2004: 302). Na análise original de Martins, este morfema é explicado como indicador de progressão do aspecto rumo a uma certa direção, continuamente, originário de um determinado local, prolongando o evento, indicando que ocorre de modo sucessivo, embora mais lentamente que o aspecto progressivo 1, e também com duração de evento não especificada. 
(1)

\author{
tir wây' râag ka' (Martins 2004) \\ 3SG ver andar devagar PROGII \\ ele foi olhando bem devagar
}

$\mathrm{Na}$ análise dos novos dados de 2013/2014 (a partir de (2)) esse morfema parece não ter nenhuma conotação aspectual, indicando somente que o agente do verbo realiza a ação na enquando deitado em rede ${ }^{23}$. Este morfema deve ser removido da lista de marcadores aspectuais, com base nos dados recentes, embora a discrepância detectada possa se dever a variação nos idioletos dos falantes elicitados.

(2) *dâw'ãy dôo’ utb ka' dâwtee-ũuy

mulher CAUS acordar PROG2 criança-AFET

a mulher está acordando a criança

(3) *dâw'ãy dôo’ çom ka’ dâwtee-ũuy

mulher CAUS banhar PROG2 criança-AFET

a mulher está banhando a criança

(4) *dâwtee wĩnh ka'

criança trabalhar PROG2

a criança está trabalhando

(5) *dâw‘ãy do wĩnh ka' dâwtee-ũuy

mulher CAUS trabalhar PROG2 criança-AFET

a mulher está deixando/mandou a criança ainda estar trabalhando

Aqui vemos que vários verbos, como 'trabalhar', 'banhar', cuja ação semanticamente incompatível com 'estar deitado' (ao menos no mundo indígena), são agramaticais com $k a^{\prime}$, o que fortalece a hipótese de que o marcador serve apenas para indicar a posição corporal do argumento.

\footnotetext{
${ }^{23}$ Para 'estar deitado no chão', o Dâw possui o verbo yet.
} 
(6) * dâwtee suuk ka'

criança caçar PROG2

a criança está caçando

O verbo 'caçar', incompatível com 'estar deitado', não pode levar $k a$ '.

(7) dâw‘ãy dôo’ kog'ogn ka’ dâwtee

mulher CAUS desmaiar PROG2 criança

a mulher deixou a criança desmaiando na rede/deitado

No exemplo acima é interessante observar que o objeto do verbo é que está 'deitado'.

Acima vemos claramente que o marcador glosado PROG2 nada indica senão a posição 'deitado (na rede)'.

(8) dâwtee $\operatorname{kog}^{6} \operatorname{ogn} \quad \mathbf{k a}^{\prime}$

criança desmaiar PROG2

a criança está desmaiando deitada

(9) dâwtee uнb ka'

criança acordada PROG2

a criança está acordada deitada na rede

(10) dâwtee yũt ka' naap

criança matar PROG2 barata

a criança está matando a barata (deitada na rede)

(11) dâw‘ãy ya ka' tax

mulher assar PROG2 anta

a mulher está assando a anta deitada na rede

(12) dâwtee kâs ka' dâw'ãy

criança morder PROG2 mulher

a criança mordeu a mulher que estava na rede 
(13) dâwtee 'ãa ka'

criança dormir PROG2

a criança está dormindo

(14) dâwtee yũt ka' naap

criança matar PROG2 barata

a criança está deitada na rede matando a barata

(15) dâw'ãy ya' ka' táx

mulher assar PROG2 anta

a mulher assou a anta deitada na rede

(16) dâwtee kâs ka' dâw'ãy

criança morder PROG2 mulher

a criança deitada mordeu a mulher

(17) dâwtee yũt ka' nap

criança matar PROG2 barata

a criança matou a barata deitada

Em (18) vemos que sentenças com o marcador $k a^{\prime}$ podem vir seguidas do sintagma preposicional yeg ked 'dentro da rede'.

(18) tir tôg mẽr xub-'wĩnh nã ka' xâd yeg ked 3SG filha não.haver REFL-mexer FUT estar.deitado DUR rede dentro A filha dela nem se mexia deitada na rede

No trabalho de campo de 2015 esse morfema não foi testado extensivamente, pois os falantes confirmaram que significa apenas 'deitado na rede'. 


\subsubsection{Progressivo 3 te (ainda)}

Não deriva de verbo, mas do nome te 'filho, filhote' (Martins 2004: 302), compartilhando com o nome cognato a noção de algo em desenvolvimento, que ainda acontece.

(1) 'wey yum te

mucura estar-viva PROG3

a mucura ainda está viva.

O morfema de aspecto cognato no idioma Hup é tae e também significa 'filho', indicando uma tendência da família Nadahup a usar o termo 'filho, criança' como morfema funcional verbal. Em Hup e Dâw este marcador ocorre com alta frequência, sendo comumente traduzido pelo advérbio 'ainda', tanto em Dâw quanto em Hup.

(2) dâw'ãy dôo' uub te dâwtee-ũuy

mulher CAUS acordar PROG3 criança-AFET

a mulher está acordando a criança

(3) *dâwtee uub te

a criança está acordada (mas deitada na rede)

(4) dâw'ãy dôo’ çom te dâwtee-ũuy mulher CAUS acordar PROG3 criança-AFET

a mulher está acordando a criança

(5) dâwtee wĩnh te

criança trabalhar PROG3

a criança ainda está trabalhando

(6) dâw`ãy do wĩnh te dâwtee-ũuy

mulher CAUS trabalhar PROG3 criança 
a mulher está deixando/mandou a criança ainda estar trabalhando

(7) dâwtee suuk te

criança caçar PROG3

a criança está caçando

(8) dâw'ãy dôo’ $\operatorname{kog}^{\text {‘ } o n g ~ t e ~ d a ̂ w t e e ~}$

mulher CAUS desmaiar PROG3 criança

a mulher ainda deixou a criança desmaiada

(10) dâwtee $\operatorname{kog}^{6}$ ogn te

criança desmaiar PROG3

a criança ainda está desmaiando

(11) dâwtee yũt te naap

criança matar PROG3 barata

a criança está matando a barata

(12) dâw'ãy ya' te taax

mulher assar PROG3 anta

a mulher ainda está assando a anta

(13) dâwtee kâs te dâw'ãy

criança morder PROG3 mulher

a criança ainda está mordendo a mulher

(14) dâwtee 'ãa te

criança dormir PROG3

a criança ainda está dormindo

(15) tir siib te

3sg beliscar PROG3

ele está beliscando 
(16) 'ãr wây te tir-ũuy

1sg ver PROG3 3sg-AFET

eu ainda estou vendo ele

(17) 'ãr wây-ẽr te tir-ũuy

1sg ver-NEG PROG3 3sg-AFET

eu ainda não vi ele

(18) teen tir yũt te rãap

agora 3sg PERF1 PROG2 peixe

agora ele ainda está matando peixe

(19) teen tir yũt-ẽr te rãap

agora 3sg matar-NEG PROG3 peixe

agora ele ainda não matou o peixe

(20) rid yũt-ẽr te naap-ũuy

3pl matar-NEG PROG3 barata-AFET

eles ainda não estão matando/não mataram a barata

(21) ‘ãr yũt-ẽr te wutd naap

1sg matar-NEG PROG3 FRUST barata

eu não tinha matado barata

Em (21) vemos a compatibilidade de te com o frustativo $w \mathfrak{z} d$, gerando um passado anterior, bem como em (19) com o verbo negado, denotando que a ação ainda não foi feita.

(22) bê' tas te

pau torto PROG3

o pau ainda está torto

(23) bê' tas-ẽr te

pau torto-NEG 
o pau ainda está reto/ainda não está torto

(24) nâx ba' te

água fria PROG3

a água ainda está fria

(25) nâx ba'ẽr te

água fria-NEG PROG3

a água ainda não está fria

(26) cem kub te

noite escura PROG3

a noite ainda está escura

(27) top yẽw te

casa bonita PROG3

a casa ainda está bonita

De (22) a (27) observamos a perfeita compatibilidade de te com verbos estativos, sem qualquer alteração em seu significado.

(28) ãr bâas te nâxpog

1sg atravessar PROG3 rio

eu ainda estou atravessando o rio

(29) * bub ‘ãr bâas te nâxpog

amanhã 1sg atravessar PROG3 rio

(30) bub ‘ãr bâg nã te nâxpog

amanhã $1 \mathrm{sg}$ atravessar rio

amanhã ainda vou estar atravessando o rio 
Em (28) testamos o marcador com o verbo bâas, 'atravessar'. No futuro ele só é compatível com o marcador de futuro $n \tilde{a}$.

(31) bertâg kasãm te

árvore morrer PROG3

a árvore ainda está morrendo

(32) teen cemid te

agora cedo PROG3

agora ainda é cedo

(33) bub ‘ãr pilsij wĩnh te

amanhã 1sg precisar trabalhar PROG3

amanhã eu ainda preciso trabalhar

(34) bub 'ãr deel wĩnh te

amanhã 1sg poder trabalhar PROG3

amanhã eu ainda vou poder trabalhar

A tradução constante de te como 'ainda' com todos os tipos de verbos em vários aspectos não nos deixa opção senão classificar o morfema como advérbio indicador de ação ou estado prolongado além do esperado, ou seja, praticamente a mesma função do nosso advérbio 'ainda'.

\subsubsection{Intensivo 1 yed (muito) e 2 'uy}

Não se originam de verbo conhecido. Podem ocorrer com eventos ativos e estativos, indicando intensidade qualitativa ou quantivativa, ou ainda um alto grau de voluntariedade do agente ao realizar o evento. Com frequência esses dois marcadores ocorrem após o verbo equativo płtı, 'ser intensificado'. Os dois marcadores não se 
distinguem significativamente e podem coocorrer. Nesse caso, o marcador yed sempre ocorre antes de ' $u y$. Essa coocorrência indica intensidade máxima na execução do evento (Martins 2004).

(1) tir dó' yed nĩd

3SG Mov INTS1 assim mesmo

ela pegou e levou tudo assim mesmo

(2) tir yum tuk 'uy

3SG estar vivo querer INTS2

ele quer muito ficar vivo

Intensidade como vista em (1) e (2) não é classe aspectual. Esses marcadores parecem ser sempre satisfatoriamente traduzidos pelo advérbio 'muito', portanto nossa hipótese é de que teriam função meramente adverbial de intensidade no idioma, sem conotação aspectual.

Esses morfemas só ocorrem no slot pós-verbal em Dâw, como os morfemas verbais modo-aspectuais, em contraste a advérbios de tempo, lugar e modo do idioma, que podem ocorrer livremente, tipicamente no início ou no final da sentença.

Os testes de 2014 mostraram que esses morfemas não possuem conotação verbal. Sentenças com ' $u y$ foram interpretadas como se esse ' $u y$ fosse a conjunção subordinante 'que' ou 'se', caso de homofonia, indicando possível obsolescência do morfema indicador de intensidade. Sentenças com yed tiveram esse morfema traduzido por 'muito' ou simplesmente omitido na tradução. A locução putd yed é a maneira mais comum de expressar 'muito' com verbos estativos e ativos.

Os testes de 2015 não focaram nesses morfemas, mas foi interessante a ocorrência em (3):

(3) bertâg kasãm-uy árvore morrer-INTS2

a árvore morreu e não sobrou nada 
Bastante 'intensa', ao contrário da maioria das traduções de sentenças com ' $u y$, em que este morfema parece não ter sentido algum, quando não é confundido com o homônimo 'uy, 'porque'.

\subsection{Outras considerações sobre os marcadores de aspecto}

Nota-se ainda que os marcadores de aspecto não são obrigatórios: muitas vezes os verbos ocorrem sem nenhum deles, e muitos verbos lexicais podem ser usados para marcar aspecto, modalidade e uma série de nuances, em construções aparentemente seriais ou concatenativas, como é típico também das línguas isolantes com marcadores de aspecto independentes em outras partes do mundo, como no leste da Ásia.

A quase totalidade de sentenças espontâneas contendo apenas um verbo, sem nenhum dos marcadores de aspecto, modo e tempo e outros dentre os analisados aqui, é traduzida uniformemente pelo pretérito perfeito em português, o que pode significar que o tempo passado é um tempo não marcado em Dâw, e a própria perfectividade pode ser o aspecto não marcado default no idioma, com os marcadores yũt e yow apenas enfatizando a perfectividade opcionalmente.

Nota-se que nenhum dos marcadores se revelou meramente imperfectivo. Quando necessário, a imperfectividade deve ser indicada por advérbios e pelos marcadores de aspecto habitual analisados acima. Em um caso apenas, na sentença (9) da seção 4.3.4, tir yam wztd, o marcador wutd com verbo ativo foi traduzido no passado progressivo, 'ele estava dançando', como se fosse um marcador de imperfectividade ou passado contínuo.

Além dos dois morfemas habituais 'weer e tâg, uma pesquisa pelo corpus de Narrativas Dâw revelou que o verbo pun (costumar) é bastante usado no contexto narrativo de 
imperfectividade e habitualidade e pode estar se gramaticalizando, pois tende a ocorrer após o verbo, aparentemente no mesmo slot reservado para os verbos concatenativos, axuliares, modais e os morfemas funcionais analisados nesta dissertação:

(1) nũkêe' id wĩinh xôo' êe' buuy rũuy rõt id wĩinh xôo pun êe xaay antigamente 1pl trabalhar circular PASS branco junto longe trabalho circular têen xaay pun êe xaay têen xaay quando mata costumar PASS mata mato. antigamente, nós andávamos trabalhando com os brancos, nós andávamos trabalhando no meio da mata

(2) id wĩinh pun nũkêe' nãp yêe rõt id wĩnh xôo' pun êe' id $1 \mathrm{pl}$ trabalhar costumar antigamente piaçava longe $1 \mathrm{pl}$ trabalhar circular

\section{balak xaay têen}

barraca mato quando

nós trabalhávamos, antigamente, na piaçava, (era) longe, nós andávamos, trabalhávamos na nossa barraca, era no meio da mata

(3) id wĩinh buuy rũy biixid çêmẽd id wĩinh pun

$1 \mathrm{pl}$ trabalhar branco junto de-graça de-manhã $1 \mathrm{pl}$ trabalhar costumar çêmẽd id rãm xaay

de-manhã $1 \mathrm{pl}$ ir mata nós trabalhávamos com os brancos de graça de manhã, nós trabalhávamos de manhã, nós íamos à mata

(4) Kas suuk pis sutd buuy nõo' pun idũuy' coisa farinha pouco ? branco dar costumar 1pl.AFET só um pouquinho de farinha que os brancos nos davam

(5) nũ' wât id wĩinh pun kuat xutum abug id nâar pun outro dia $1 \mathrm{pl}$ trabalhar costumar quatro meses daí 1pl levar costumar xaay abug id pular pun xaay waa dâr mato daí $1 \mathrm{pl}$ sofrer costumar 
às vezes nós trabalhávamos quatro meses, aí nós conduzíamos no mato, aí nós sofríamos muito no mato, os velhos

O verbo pun também ocorre em sentenças habituais no presente:

(6) aag dâwãay 'wĩinh' pun' rid reew rẽd

esta mulher trabalhar costumar 3 pl todas junto

essas mulheres trabalham todas juntas

Em (7) ele aparece sufixado com o marcador de passado -êe':

(7) id pular xôo punêe' nũkedêe' gayãal ẽr mĩi mẽr id ray nã'

$1 \mathrm{pl}$ sofrer circular costumar-PASS antigamente-PASS ganhar NEG

nós andávamos sofrendo, antigamente, sem ganhar nada

Ou seja, além dos morfemas tâg e 'weer analisados neste trabalho, o Dâw ainda possui outro verbo gerador de predicados habituais. O verbo xôo, visto em (7) acima também ocorre para expressar habitualidade e continuidade em outras sentenças da narrativa.

Também durante as amostras foi testado como os falantes expressam o conceito perfeito negado: 'não fazer mais algo, ter parado de fazer algo'. Os falantes expressaram essa noção com a partícula $m \tilde{a}$ e o verbo negado, sendo que o verbo afirmativo com esse $m \tilde{a}$ foi traduzido como 'ainda faço', como vemos de (8) a (11):

(8) 'ãr suuk mã 'yãmxu'-

1 sg caçar ? onça-AFET

eu ainda vou caçar a onça

(9) 'ãr suuk-ẽr mã 'yãmxu'--̃uy

1sg caçar-NEG ? onça-AFET

eu não vou mais caçar onça

(10) tir rẽd mẽr mã

3 sg possuir não.ter ? 
ele não tem mais

(11) tir rẽd-ẽr mã

3sg possuir-NEG?

ele não tem mais

(12) 'ãr nĩ-ẽr mã bug

1sg estar-NEG ali

eu não estou mais ali

Outros exemplos:

(13) paas be'-ẽr mã

pedra dura-NEG ?

a pedra não está mais dura

(14) ‘ãr nê-ẽr mã top

1sg fazer-NEG ? casa

ele não está mais fazendo casas

(15) tir weed-ẽr mã

3 sg comer-NEG ?

ele não come mais

Esse uso compete com o ingressivo -ãm (glosado TEL de 'télico', nomenclatura de Martins) negativo em significado:

(16) tir nẽ-ẽr-ãm top

3sg fazer-NEG-TEL

ele não está mais fazendo

(17) rid pitaa-ẽr-ãm

3pl ficar-NEG-TEL

eles não ficaram mais 
(18) tir mẽr-ãm

3sg não.ter-TEL

ele não tem mais/ ele já não tem

(19) tir yok-ẽr-ãm

3sg nadar-NEG-TEL

ele já não nada

(20) tir wây-ẽr-ãm

3 sg falar-NEG-TEL

ele já não fala mais

O lexema mã não está inserido na base lexical Dâw de que dispomos, nem é citado por Martins (2004) em qualquer lista de partículas verbais. Parece que no afirmativo significa algo como o nosso 'ainda' de ação adicional, ou seja, em (8) o falante parece estar dizendo que vai fazer várias coisas, e além disso 'ainda vai caçar onça'. Talvez tenha uma função perfeita de 'informação atualizada' similar à que o marcador sentencial de aspecto Chinês le e Cantonês laa possuem. Em Chinês, 'ele não vai caçar' é tā bù huì shòuliè [3sg NEG FUT caçar], mas ao adicionarmos a partícula le sentencial, tā bù tā bù huì shòuliè le [3sg NEG FUT caçar PERF] significa que ele cancelou a ação, 'ele não vai mais caçar'.

Vemos assim que o quadro geral de morfemas aos quais se pode atribuir alguma aspectualidade em Dâw fica sendo o seguinte:

\begin{tabular}{|l|l|}
\hline Aspecto & Morfema / verbo \\
\hline imperfectivo & zero \\
\hline perfectivo & yũt \\
\hline perfectivo (movimento direto) & yow \\
\hline perfeito ‘informação atualizada'? & $m \tilde{a}$ \\
\hline ingressivo & $-\tilde{a} m(r \tilde{a} m)$ \\
\hline télico quantificador & $r \tilde{u} '$ \\
\hline
\end{tabular}




\begin{tabular}{|l|l|}
\hline habitual & tâg, ptn', weer $^{\text {' }}$ \\
\hline repetitivo 'de novo' & beey \\
\hline prolongado 'ainda' & te \\
\hline
\end{tabular}

Tabela 15 - lista atualizada de morfemas de aspecto

\section{Modo}

\begin{tabular}{|l|l|}
\hline Modo & verbo / morfema \\
\hline potencial & deel (pré-verbal) \\
\hline obrigação & pilsij (pré-verbal) \\
\hline desiderativo & tuk \\
\hline imperativo & -or \\
\hline imperativo negativo & -ẽrir \\
\hline frustrativo-condicional & wutd \\
\hline
\end{tabular}

Tabela 16 - lista atualizada de morfemas de modo

O verbo pilsij claramente deriva do português 'precisar', e o verbo deel deve derivar do português 'poder', especialmente porque uma variante desse verbo claramente calcada do português, pudeel, foi encontrada nas Narrativas. Isso deve explicar sua posição préverbal, também calcada do português. Quando questionados sobre como expressar noção de 'dever, precisar fazer algo', os falantes inicialmente disseram que era com tuk 'querer' mesmo, ou seja, o Dâw não distinguia muito bem a noção de 'querer' da noção de 'ter que, dever', depois se lembraram de pilsij. Eventualmente esse novo verbo foi emprestado, ao que parece bem recentemente, não consta de Martins (2004) e talvez nem todos os falantes o tenham adotado.

Nas amostras de 2015 também foi identificada uma construção modal não detectada antes, com um morfema não identificado, pay:

\section{(21) tir nĩ pay tir top}

3sg estar? 3sg casa

ele deve estar em casa (na casa dele)

\section{(22) tir wĩnh pay teen}


3sg trabalhar? agora

ele já deve estar trabalhando

(23) tir need pay

3 sg vir?

ele deve estar vindo

(24) tir need te pay

3sg vir PROG3?

ele ainda deve estar vindo

(25) rid need rũ' pay

3pl vir PERF2 ?

eles todos devem vir

Ou seja, o morfema pay (homófono de pay, pronome interrogativo 'o que') colocado após o verbo indica suposição de alta probabilidade pelo falante.

\section{Tempo}

\begin{tabular}{|l|l|}
\hline Tempo & morfema \\
\hline presente & zero \\
\hline passado & $-\hat{e} e^{\prime}$, wutd \\
\hline futuro & $-a y, n \tilde{a}$ \\
\hline
\end{tabular}

Tabela 17 - lista atualizada de morfemas de tempo

É bem provável que tanto -êe' quanto wutd combinem tempo passado com aspecto imperfectivo, com base nos dados disponíveis.

\section{Evidencialidade}

\begin{tabular}{|l|l|}
\hline Evidencialidade & morfema \\
\hline reportativa & mãr \\
\hline
\end{tabular}

Tabela 18 - morfema de evidencialidade 
Quanto à existência em si de uma série de morfemas verbais multifuncionais, verificamos na nossa breve pesquisa, sobre os idiomas tipologicamente similares do Dâw, que não é de modo nenhum anormal que um idioma tenha uma vasta gama de morfemas verbais funcionais aspectuais e não aspectuais, ou 'operadores verbais' como são denominados em certas obras ${ }^{24}$, inclusive alguns de funcionalidade difícil de classificar e em alguns casos bastante exótica.

Nos idiomas isolantes e de pouca ou nennhuma morfologia verbal como o Dâw, como os idiomas do leste e sudeste asiático, encontramos em alguns casos uma gama similarmente ampla e multifuncional de operadores verbais.

O Chinês Mandarim é geralmente o mais citado, mas não tem tanta riqueza morfemas aspectuais verbais. O cantonês, por exemplo, já possui uma gama mais ampla, e idiomas como o tailandês, o birmanês e o vietnamita possuem gamas que lembram as do Dâw e do Hup.

\section{Chinês mandarim:}

perfectivo - le (do verbo liao, 'entender')

perfectivo experiencial - guo (do verbo guo, 'passar')

completivo - wan (do verbo 'terminar', possível quantificação dos argumentos)

ação continuativa simultânea ou partícipio ativo - zhe

progressivo - zài (preposição locativa)

passado - construção shì (cópula) + verbo + de (partícula genitiva)

futuro - huì

Tabela 19 - operadores verbais em Chinês Mandarim

\section{Cantonês:}

perfectivo $-z o$

experiencial - guo (do verbo 'passar')

\footnotetext{
24 'Verbal operators' é o nome coletivo dado aos morfemas verbais aspectuais e de outras funções no Birmanês na obra Aspect in Burmese: Meaning and Function, Nicoletta Romeo, 2008.
} 


\begin{tabular}{|l|}
\hline completivo - yuhn (do verbo 'terminar') \\
\hline exaustivo - saai (tb de 'terminar', quantificação universal dos argumentos) \\
\hline progressivo - gan \\
\hline durativo - zyu \\
\hline pontual - han \\
\hline habitual - hai (preposição locativa) \\
\hline incoativo - heisoenglai \\
\hline contunuativo - lokheoi \\
\hline
\end{tabular}

Tabela 20 - operadores verbais em Cantonês

\begin{tabular}{|l|}
\hline Tailandês: \\
\hline perfectivo - leew, sia/sa \\
\hline semi-perfectivo - kheun (ação interrompida) \\
\hline imperfectivo - khao \\
\hline progressivo - yu (preposição locativa), gamlang \\
\hline iminente - ja \\
\hline recente - phêng \\
\hline perfeito - dai, ma \\
\hline incoativo - rêm \\
\hline perfectivo beneficial - wai \\
\hline terminativo/télico - set (gramaticalizado do verbo 'terminar') \\
\hline 'lamentativo' - ao (algo como 'que pena, infelizmente') \\
\hline
\end{tabular}

Tabela 21 - operadores verbais em Tailandês

\begin{tabular}{|l|}
\hline Birmanês: \\
\hline perfectivo - pi (do verbo 'terminar') \\
\hline habitual - $t a$ ' (do verbo 'conhecer'), le (do verbo 'praticar') \\
\hline contínuo - ne \\
\hline resultativo - tha \\
\hline direcionais - la (vir), thwa (ir) \\
\hline benefactivo - be (do verbo 'dar') \\
\hline
\end{tabular}




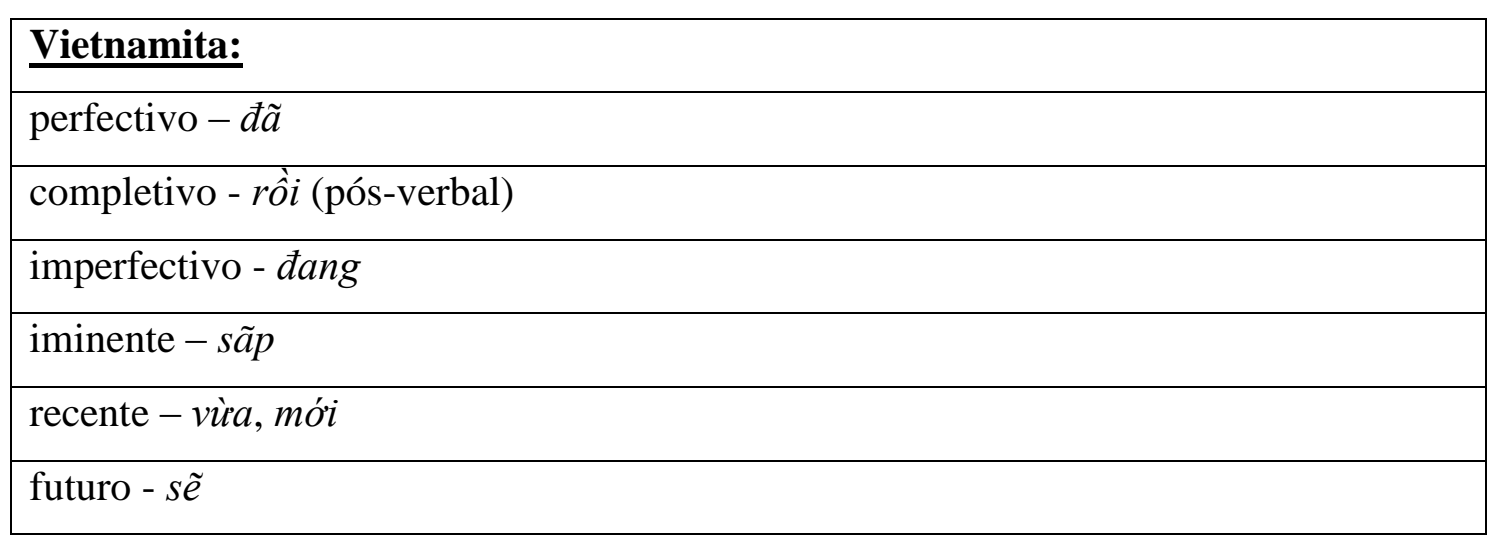

Tabela 23 - operadores verbais em Vietnamita

A lista acima não é exaustiva para cada idioma, já que as fontes citam ainda mais 'operadores verbais' ou 'marcadores de aspecto' (que nem sempre são aspecto, mas se alinham muitas vezes sintaticamente) muitas vezes de função quase inclassificável.

Nota-se que o habitual do Birmanês também vem do verbo 'conhecer', como em Dâw, mas que no chinês e cantonês o verbo 'passar' se gramaticalizou como perfectivo experiencial (ter feito algo pelo menos uma vez, ter 'passado' por uma experiência).

Além disso, como em Dâw e outras línguas da região, nas línguas asiáticas acima, o marcador de perfectividade denota ação no passado com verbos ativos/ dinâmicos, mas com verbos estativos denota estado atual atingido por meio de transformação no passado. Contraste os exemplos (a), com verbo ativo/dinâmico e (b) com verbo estativo, em Vietnamita:

(a) họ đã đi đến trường (Vietnamita)

3pl PERF ir chegar escola

eles foram à escola

(b) bây-giờ tôi đã có đủ tiền (Vietnamita)

agora 1 sg PERF ter suficiente dinheiro

agora eu tenho dinheiro o suficiente 
E as sentenças (c) e (d) com verbos ativos, em contraste com (e) e (f) com verbos estativos em Tailandês:

(c) khaw pay thamngang leew (Tailandês)

3 sg ir traballho PERF

ele foi ao trabalho

(d) rotmee maa leew (Tailandês)

trem vir PERF

o trem chegou

(e) thuuk leew (Tailandês)

correto PERF

está correto

(f) phoo leew (Tailandês)

suficiente PERF

é suficiente

Em seções anteriores expusemos exemplos similares em Chinês Mandarim. Como não existe nenhuma relação genética apreciável nem contato histórico entre os povos do extremo oriente e os povos da Amazônia, consideramos que se trata de um fenômeno possivelmente universal, derivado das propriedades semânticas dos verbos ativos ou dinâmicos em contraste com os estativos e a interação desses verbos com a categoria de perfectividade.

Além disso, detectamos outro paralelo entre um idioma isolante asiático e as línguas do Alto Rio Negro: no Cantonês, uma das partículas perfectivo-completivas, saai (glosado abaixo COMPL, de completivo) segundo certos autores ${ }^{25}$, desenvolveu uma função de quantificação universal dos argumentos do verbo, como vemos em (g) e (h):

(g) keoih jam saai di zau (Lee, 2012)

\footnotetext{
${ }^{25}$ Lee 1994, Matthews \& Yip 1994, Tang 1996, coletados aqui a partir de Teng 1996
} 
3sg beber COMPL DET.sg vinho

ele bebeu todo o vinho

(h) keoih.deih za saai leng ce (Teng 1996)

$3 \mathrm{pl}$ dirigir COMPL novo carro

eles todos dirigem carros novos

Em (g) vemos que a quantificação nem sempre se aplica ao objeto, neste caso é aplicada ao sujeito, os autores dos trabalhos de Cantonês pesquisados dizem que a quantificação pode afetar o sujeito ou o objeto ou ambos dependendo de diversas considerações semânticas.

(i) keoih jauh saai seoi (Teng 1996)

3sg nadar COMPL água

ela terminou de nadar

Em h vemos um predicado cujo sujeito não pode ser quantificado, em que saai acaba sendo interpretado como 'terminar', quantificando a ação apenas.

(j) * keoih fan saai (Teng 1996)

3sg dormir COMPL

(k) keoih.deih fan saai (Teng 1996)

3 pl dormir COMPL

eles todos dormiram

Vejamos que em (g) o único argumento do verbo está no singular e não faz sentido quantificá-lo, pois não é possível 'dormir parcialmente'. Já com argumento plural, a sentença se torna gramatical e quantifica universalmente o argumento sujeito. Esse exemplo em cantonês espelha perfeitamente o que ocorre no Dâw, na sentença (5) da seção 3 (perfectivo 2 rü') do capítulo 4, que repetimos aqui em (l) abaixo:

(1) * ‘ãr ãa rũ̃' (trabalho de campo 2015) 
1sg dormir PERF2

Em que o argumento singular torna a noção de quantificação do morfemar rũ' no Dâw, como saai em Cantonês, impossível, embora possamos especular que com um predicado como 'sujar-se' seja possível o argumento singular ser quantificado, pois pode haver um 'sujar-se' parcial e um total, o que não ocorre com 'dormir'.

Em vemos um par de sentenças intransitivas, uma agramatical com sujeito singular, e outra gramatical com sujeito do plural:

(m) * gwo sibing sei saai

DET.sg soldado morrer COMPL

(n) *di sibing sei saai

DET.pl soldado morrer COMPL

os soldados todos morreram

Ou seja, a leitura com sujeito singular é agramatical porque geraria a sentença absurda 'o soldado morreu todo'.

E existem vários outros casos interessantes de paralelismos e contrastes entre as várias línguas do mundo que expressam aspecto por morfemas específicos.

Vemos que este trabalho foi muito frutífero para o estudo não só do aspecto em um idioma ainda pouquíssimo explorado da Amazônia, mas também para a compreensão do aspecto, modo, tempo, quantificação e tipologia linguística geral das línguas da área do Alto Rio Negro e das línguas do mundo no geral.

Vários fenômenos encontrados no Dâw foram detectados em outros idiomas do Alto Rio Negro, e vários fenômenos ligados a aspecto e quantificação das línguas do Alto Rio Negro foram encontrados em outros idiomas tipologicamente similares de outras 
áreas do mundo. Esperamos que este breve estudo contribua assim para a compreensão da Gramática Universal e do fascinante mundo das línguas e da mente humana. 


\section{Bibliografia}

AGRELL, Sigurd, Aspektänderung und Aktionsartbildung beim polnischen Zeitworte, 1908

AIKHENVALD, A. The Languages of the Amazon. Oxford University Press. 2012

AIKHENVALD, A. A Grammar of Tariana, from Northwest Amazonia, 2006

BACH, Emmon, Linguistic Universals and Particulars, 2004

BACH, Emmon, The Algebra of Events, in Linguistics and Philosophy, 1986

BACH, Emoon, On Time, Tense, and Aspect: An Essay in English Metaphysics, 1981

BIRDIE, West \& WELCH, Betty, Gramática Pedagógica del Tucano, Fundación para el desarollo de los pueblos marginados, Colômbia, 2004

BIRDIE, West, Gramática Popular del Tucano, Bogotá, Summer Insitute of Linguistics, 1980

BYBEE, Joan L, Morphology: a Study of the Relationship between Meaning and Form, 1985

COMRIE, Bernard, Aspect. Cambridge University Press, 1976

COMRIE, Bernard, The Syntax of Causative Constructions, 1976

DA CRUZ, Aline, Fonologia e Gramática de Nheengatu, Tese de Doutorado, Vrije Universiteit Amsterdam, 2011

DAO, DAN VAN, Some Vietnamese Students' Problems with English Grammar: A Preliminary Study, 2008

FRAWLEY, William, Linguistic Semantics, 1992

DIXON, R. M. W. \& AIKHENVALD, A. Y. The Amazonian Languages. Cambridge: Cambridge University Press. 1999

EPPS, Patience. A grammar of Hup. Tese de doutorado. University of Virginia. Charlottesville, Virginia, 2005

EPPS, Patiens \& BOLAÑOS, Katherine, Linguistic classification of Kakua, a language of northwest Amazonia, 2009

GAREY, Howard B. Verbal Aspect in French, in Language, Vol 33 no. 2, 1957

FILIP, Hana, Lexical Aspect, 1991

FILIP, Hana, Quantification, Aspect and Lexicon, 1996 
FILIP, Hana, capítulo 25 Lexical Aspect, in The Oxford Handbook of Tense and Aspect, 2001

FILIP, Hana, The Telicity Parameter Revisited, 2005a

FRAWLEY, William, Linguistic Semantics, Routledge, 1992

ISAČENKO, Alexander, Die russische Sprache der Gegenwart, 1962

KLEIN, Wolfgang, Time in Language. 1994

KRATZER, Angelina, Telicity and the meaning of objective case, Cambridge MIT Press, 2004

KRIFKA/HOCK. Aspekt und Zeitkonstitution, 2002/2003

HALE, K.; KEYSER, S. J. Prolegomenon to a Theory of Argument Structure. Cambrigde: MIT Press, 2002

LEE, Peppina Po-Lun, Cantonese Particles and Affixal Quantification, 2012

MARQUES DE CARVALHO, Andrea, O Auxiliar Aspectual Tyka em Karitiana, Dissertação de mestrado. Universidade de São Paulo, 2010

MARTINS, Silvana. Fonologia e Gramática da Língua Dâw. Tomo I e II. Tese de doutorado. Universidade de Amsterdã. Amsterdã. 2004

MARTINS, Silvana, Análise da Morfossintaxe da Língua Dâw e Sua Classificação Tipológica. Florianópolis: UFSC. Dissertação de mestrado. Universidade Federal de Santa Catarina, Florianópolis, Brasil, 1994

MARTINS, Valdeir, Análise Prosódica da Língua Dâw Numa Perspectiva Não Linear. Florianópolis: UFSC. Dissertação de mestrado. Universidade Federal de Santa Catarina, Florianópolis, Brasil. 1994

MARTINS, Valdeir, Reconstrução do Proto-Maku Oriental. Tese de doutorado. Universidade de Amsterdã. Amsterdã, 2005

MATTHEWS, S. \& YIP, Virginia, Bilingual and multilingual acquisition of Chinese, 2009

MOURELATOS, Events, processes and states, 1978

OSPINA, Bozzi, .A.M. Les structures élémentaires du Yuhup Maké, Langue de l'amazonie colombienne: morphologie et syntaxe. Tese de doutorado. Universidade de Paris, 2002

ROMEO, Nicoletta, Aspect in Burmese: Meaning and Function, John Benjamins Publishing, 2008

SANCHEZ-MENDES, Luciana, A Modificação de Grau em Karitiana. Universidade de São Paulo, 2014 
SANCHEZ-MENDES, Luciana, A Quantificação Adverbial de Grau em Karitiana. Universidade de São Paulo, 2009

SANDALO, Filomena, Violação da Condição C em Kadiweu, Unicamp, 2001

SASSE, H.-J. Recent activity in the theory of aspect: Accomplishments, Achievements or just non-progressive state, 2002

SMITH, David, Thai: An Essential Grammar, Routledge, 2013

SWART, H. Aspect shift and coertion, in Natural Language and linguistic theory, 1998

TALMY, Leonard. Lexicalization patterns: Semantic structure in lexical forms. In Shopen 1985d 57-14

TENG, YU-YAN ANNE, Aspectuals in Cantonese: the case of saai, UCL Working Papers in Linguistics, 1996

VENDLER, Zeno, Verbs and Times, 1957

VERKUYL, Aspectual Classes and Aspectual Composition, 2002

WEIR, E.M. Helen. 1984. A negação e outros tópicos da gramática Nadeb. Dissertação de mestrado. Universidade Estadual de Campinas UNICAMP 


\title{
Apêndice 1
}

\section{Transcrição do Trabalho de Campo Julho de 2015}

\begin{abstract}
Abaixo apresentamos a transcrição completa das amostras do trabalho de campo realizado em São Gabriel da Cachoeira em julho de 2015. Para uma maior brevidade, não oferecemos a glosa completa de cada frase, já que praticamente todas as sentenças relevantes ao estudo foram incluídas no texto principal da dissertação com glosa e tradução, e porque existe uma grande repetitividade de um pequeno número de vocábulos. Será assim dada apenas a tradução dos principais vocábulos em cada bloco de amostras.
\end{abstract}

Alguns termos recorrentes:

bub - amanhã

yor - hoje

cem - ontem/ à noite/ noite

wâat wap - todo dia

têen - agora

-ẽr - sufixo de negação

dâw'ãy - mulher

dâwtee - criança

dâwxut - homem

DOMINGO

FALANTE: MATEUS

siib - beliscar

tir siib yow dâw'ãyũuy - ele beliscou a mulher

tir siib te - ele está beliscando

paar - saber

\begin{tabular}{|l|}
\hline 'ãr paar yow - eu já sei \\
\hline 'ãr paarẽr ram yow - eu não sei mais \\
\hline 'ãr paar te - eu sei/ ainda estou sabendo \\
\hline 'ãr paarẽr te - eu não sei ainda \\
\hline
\end{tabular}


wây - ver

'ãr wây tirũuy - eu vi ele

‘ãr wây yow tirũuy - eu já vi ele

"ãr wâyẽr yow tirũuy - *

'ãr wây te tirũuy - eu ainda estou vendo ele

'ãr wâyẽr te tirũuy - eu ainda não vi ele

weed - comer; dep - carne

'ãr weed yow dep - eu já comi carne

'ãr weedẽr you dep - *

'ãr weedẽr dep - não estou comendo carne

bub 'ãr weed yow dep - *

'ãr weed yũtãm deo - eu já comi

'ãr weed yed yow tir dep - eu já comi a carne dele

‘ãr weed yedãm dep - eu já comi a carne

'ãr rẽk sibe - eu gosto de xibé

‘ãr âg rẽke' sibeũuy - eu gostava de tomar xibé

'ãr âg rẽkẽr mã xibeũuy - eu gostava de tomar xibé mas não gosto mais

'ãr rẽk yow sibe - eu estou gostando

'ãr âg rẽkẽree sibeũuy - eu gostava de beber xibé

teen 'ãr âg rẽk yow sibeñuy - agora eu gosto de tomar xibé

teen 'ãr âg rẽk te sibeũuy - até agora estou gostando de tomar xibé

tuk - querer

'ãr tuk pud/ rew rãap - eu quero muitos peixes

teen 'ãr tuk yow réw rãap - agora eu quero muitos peixes

teen tukẽr yow rãap - *

teen tukẽr te rãap - eu ainda não quero peixe

tir yũt yow rãap - ele já matou o peixe

teen tir yũt yow rãap - *

teen tir yũt te rãap - ele ainda está matando

teen tir yũtẽr te rãap - agora ele ainda não matou o peixe

$\mathrm{kub}$ - escuro

cem kub yow - *

cem kub te - *

teen cem kub - agora a noite está escura

teen cem kubãm - *

cem kub rãm - a noite ficou escura

be - pau 
tas - torto

be tas rãm yow - o pau já ficou torto

be tasẽr - o pau não está torto

be tasẽr rãm - o pau ficou torto

be tas te - o pau ainda está torto

be tasẽr te - o pau ainda está reto

nâx - água

ba' - frio

nâx ba' rãm - a água já ficou fria

nâx ba' yow - * (a água ficou fria)

nâx ba' te $-\mathrm{a}$ água ainda está fria

nâx ba'ẽr te - a água ainda não está fria

dâwtee yũt yed yow naapũuy - a criança já matou a barata

dâwtee yũt te naapũuy - a criança ainda está matando a barata

rid yũtẽr te naapũuy - eles ainda não estão matando/não mataram a barata

nĩ - estar

mug - aqui

'ãr nĩ te 'mũg - eu ainda estou aqui

'ãr nĩ yow 'mũg - eu já estou aqui

'ãr nĩ̃̃r te 'mũg - eu ainda não estou aqui

'ãr nĩ̃er mã bug - eu não estou mais ali

paas - pedra

bê' - dura

paas bê' - a pedra é dura

paas bê' te - a pedra ainda está dura

paas bê'ẽr te - a pedra ainda está mole

paas bê' yow - a pedra já ficou dura

paas bê' rãm - a pedra já ficou dura

paas bê rãm te - *

paas bê'ẽr rãm - a pedra não está mais dura

paas be’ẽr mã - a pedra não está mais dura

suuk - caçar

'yãmxu' - onça

bub 'ãr suuk 'yãmxu' - amanhã vou caçar onça

bub 'ãr suuk yow 'yãmxu' -

bub 'ãr suuk te 'yãmxu' - amanhã ainda vou caçar onça

nê - fazer 
top - casa

'ãr nê top - eu faço/fiz casa

'ãr nê te top - eu ainda faço/fiz casa

'ãr nêẽr yow top - eu já fiz casa

'ãr nêẽr te top - eu ainda não estou fazendo casa

'ãr nêẽr mã top - eu não vou fazer mais casa

suuk - caçar

'ãr suuk mã 'yãmxu' ũuy - eu ainda vou caçar a onça

‘ãr suukẽr mã 'yãmxututuy - eu não vou mais caçar onça

naap - barata

ceem 'ãr yũt naap - ontem eu matei barata

ceem 'ãr yũt yow naap - *

ceem 'ãr yũt yed yow naap - ontem eu já matei barata

ceem 'ãr yũt yed yũtam naapũuy - ontem eu já tinha matado a barata

ceem 'ãr yũt tuk wutd naap - ontem eu ia matar barata

'ãr yũtẽr te wutd naap - eu não tinha matado barata

\section{SEGUNDA-FEIRA}

falante: JONAS

kaswap $=$ tudo

tir nê rũ' cem - ele fez tudo à noite

tir tuk kaswap - ele quer tudo

tir tuk rũ' - ele quer tudo

tir tuk rũ'ẽr - ele não quer tudo

tur tukẽr rũ - ele não quer tudo

tir tukẽr kaswap - ele não quer nada

taax - anta

yãm - dançar

cem tir weed rũ' (yed) taaxũuy - ontem ele comeu toda a anta

bub tir weed ru' taaxũuy - amanhã ele vai comer toda a anta

cem tir weed rũ'ẽr taaxũuy - ontem ele não comeu toda a anta

cem tir weed wutd - ontem ele ia comer

'ãr wây tir weed taaxũuy - eu vi ela comer a anta 
tir yãm wutd - ele estava dançando

cem tir yãm - ontem ele estava dançando

cem dâw'ây wap yam - ontem todas as mulheres dançaram

cem dâw'ây rũ' yam - *

âg - beber

nâx - água, rio

xop - seco

'ãr âg rũ nâx - eu bebi toda a água

'ãr paar tirwap/kaswap - eu sei tudo

'ãr paar rũ' - eu sei tudo

yẽw rũ' - tudo está bem

nâx xop rãm rũ' - o rio secou todo

nâx xopẽr rãm rũ' - o rio não secou todo

yun - roupa

yu xop rũ' yunũuy - o sol secou toda a roupa

\section{TERÇA-FEIRA}

falante: SILIA

nẽed - vir

rẽd - ter, possuir

tir nẽedãm - ele veio

tir nẽedẽr-ãm - *

tir rẽd mẽr mã - ele não tem mais

tir rẽd-ẽr mã - ele não tem mais

nê - fazer

yũt - matar

tir nê-ãm - ele já está fazendo

tir nêẽr-ãm - ele não está mais fazendo

tir yũtãm naapũuy - ele já matou a barata

tir yũtãm rew naapũuy - ele matou muitas baratas

tir yũt rew - ele matou muito/muitas coisas

tir yũtãm rew - ele matou muito/muitas coisas

yok $=$ nadar

putd - muito

tir yok putd - ele nadou muito 
tir yok puแdẽr - ele não nadou muito

tir yokẽr putd - ele não nadou muito

mutwap- três

yaj - vez

yok - nadar

yẽw - bem, bom, bonito

tir yok mutwap yaj - ele nadou 3 vezes

tir yokãm puud - ele já nadou muito

tir yok putdãm - ele já nadou muito

tir yok putdẽr - ele nadou pouco

tir yokãm puudẽr - *

tir yok putdamẽr - *

tir yok yẽw - ele nada/nadou bem

tir yok yẽwẽr - ele não nada/nadou bem

tir yokãm yẽw - *

tir yok yẽwãm - ele já nadou bem

tir yok cemãm - * ele já nadou ontem

tir yokãm cem - ele já nadou ontem

tir yok yow - *

tir yok rũ' - *

rid pis rid yok rũ' - quando eles eram pequenos, eles todos nadavam

rid yokãm rũ' - eles todos foram nadar

rid yokãm rũ'ẽr - eles todos não/nem todos eles foram nadar

yokãm rãmor! - vai nadar!

yokor! - nada!

wap - quantificador universal nominal 'todos'

rid wap yok - eles todos nadaram

rid wap yok rãm bub - eles todos foram nadar ontem

rid yok rũ' bub - amanhã todos eles vão nadar

rid yok rũ'ẽr bub - amanhã nem todos eles vão nadar

rid wap yok rũ' bub - eles todos vão nadar amanhã

rid wap yokẽr bub - nenhum deles vai nadar amanhã

rid yok rũ'ẽr bub - nem todos vão nadar

rid wap yok rũ'ẽr bub - nem todos foram nadar

rid weed rũ'ẽr - nem todos comeram

rid wap weedẽr - ninguém comeu

rid wap weed rũ'ẽr - nem todos comeram

xaaylãs = carro (lit. 'lancha do mato')

yẽw - bom

‘id wây xaaylãs - nós vimos o(s) carro(s) 


\begin{tabular}{|l|}
\hline 'id wây xaaylãs wap - nós vimos todos os carros \\
\hline 'id wây rũ' xaaylãs - nós vimos todos os carros \\
\hline 'id wây rũ'ẽr xaaylãs - não vimos todos os carros (apenas alguns) \\
\hline 'id wâyẽr xaaylãs wap - não vimos nenhum carro \\
\hline 'id wâyẽr xaaylãs waapũuy - não vimos nenhum carro \\
\hline 'id wãyẽr xaaylãs yẽwũuy - não vimos nenhum carro bom \\
\hline 'id wây rũ'ẽr xaaylãs wap - não vimos todos os carros \\
\hline
\end{tabular}

'õt - chorar

\begin{tabular}{|l|}
\hline 'id ‘õtãm - nós já choramos/já estamos chorando \\
\hline 'id ‘õt yũtãm - nós já choramos \\
\hline 'id ‘õt bub - vamos chorar amanhã \\
\hline 'id ‘õtãm bub - * (vamos chorar amanhã) \\
\hline 'id 'õtãm cem - * (choramos ontem) \\
\hline 'id ‘õt putd yed - choramos muito \\
\hline 'id 'õtãm putd yed - * \\
\hline 'id 'õtam yor - * (nós choramos hoje) \\
\hline 'id 'õtãm teen - já estamos chorando agora \\
\hline
\end{tabular}

pitaa - ficar

rid pitaa - eles ficaram

rid pitaa-ãm - eles já ficaram

rid pitaa rũ' - eles todos ficaram

rid pitaa rũ'ẽr - nem todos eles ficaram

rid wap pitaa xâdẽr - ninguém ficou

rid wap pitaaẽr - ninguém ficou

bertâg - árvore

tas - torto

dep - gordo, carne

\begin{tabular}{|l|}
\hline bertâg tas - a árvore está torta \\
\hline bertâg tas-ãm - a árvore já está/ficou torta \\
\hline bertâg tas yow - a árvore já ficou torta \\
\hline bertâg tas-ãm yow - a árvore já ficou torta \\
\hline bertâg tasẽr mã - a árvore não está mais torta \\
\hline bertâg tasê' - a árvore estava torta \\
\hline bertâg tas wutud - a árvore era/estava torta \\
\hline bertâg tas tuk wutud - a árvore quase ficou torta \\
\hline dâwtee dep wutd - o menino era/estava gordo \\
\hline dâwtee depê' - o menino era/estava gordo \\
\hline dâwtee dep tuk wutd - o menino ia ficar gordo \\
ba' - frio \\
pis - pequeno \\
\begin{tabular}{|l} 
cem ba' - a noite é/está fria \\
\hline
\end{tabular}
\end{tabular}


cem ba' wutd - a noite era/estava fria

bub cem ba' wutd - * (amanhã a noite estará fria)

cem ba' yow - a noite ficou fria

cem ba'ãm - a noite já está/ficou fria

cem ba' yũt - a noite já está fria

cem ba' yũtam - a noite já está fria

cem ba' rũ' - *

cem wap ba' - todas as noites são/estão frias

bertâg tas rũ' - todas as árvores estão tortas

bertâg pis rũ' - todas as árvores são pequenas

bertâg pis weer $-\mathrm{a}$ árvore sempre é pequena

bertâg pis weerẽr - a árvore nunca é pequena

$\mathrm{kub}$ - escuro

cem - noite

cem kub - a noite é/está/era/estava escura

cem kub rũ' - *

cem wap kub rũ' - todas as noites estão escuras

cem wap kubẽr - nenhuma noite está escura

cem kub rũ'ẽr - nem todas as noites são escuras

cem kub te - a noite ainda está escura

cem kub tâg - as noites às vezes são escuras

cem kub weer - a noite sempre é escura

cem kub weerẽr - a noite nunca fica escura

cem kubãm - a noite já está escura

bub cem kubãm - amanhã a noite vai estar escura

bub cem kub nã - amanhã a noite vai ficar escura

cem kub beey - a noite vai ficar escura de novo

cem kub beeyẽr - a noite não vai ficar escura de novo

cem kub xãd - *

bertâg pis weer kuy - a árvore é sempre pequena

bertâg pis dâr - * (sem sentido)

bertâg pis ka' - * (sem sentido)

bertâg pis ta' - *

'ãr weed ta' dep - eu vou comer/como/comi carne

‘ãr wây ta' dâwteeũuy - eu vou ver/vejo/vi a criança

wây - ver

cem 'ãr wây ta' dâwteeũuy - ontem eu vi a criança

cem 'ãr wây tuk ta' dâwteeũuy - ontem eu quis ver a criança

bub ‘ãr wây tuk ta' dâwteeũuy - amanhã eu quero ver a criança 
dep - carne

'ãr weedẽr ta' dep - eu não vou comer carne

cem 'ãr weedẽr ta' dep - ontem eu não comi carne

taw - cidade

rid - para

'ãr rãm tuk ta' wutud taw rid - eu queria ir muito pra cidade

'ãr rãm tuk ta' taw rid - eu quero ir muito pra cidade

cem 'ãr rãm tuk ta' taw rid - ontem eu queria ir muito pra cidade

'ãr rãm wutd taw rid - eu ia pra cidade (mas não fui)

'ãr ramẽr wutd taw rid - eu não ia pra cidade

'ãr ram wutdẽr taw rid - *

nõx - cair

xax - aparecer

câk - pular

\begin{tabular}{|l}
\hline 'ãr nõx xãd - * (eu caí) \\
\hline 'ãr nõx xutu - eu caí \\
\hline 'ãr 'õt xâd - * (eu chorei) \\
\hline 'ãr xax xâd - eu passei \\
\hline 'ãr câk xâd - eu pulei \\
\hline 'ãr câk xâder - eu não pulei \\
\hline
\end{tabular}

po - abrir

$\operatorname{dim}-$ fechar

topyõr - porta

yãm câk dâr - o cachorro deu um pulo

'ãr dim dak dâr top yõr - eu fechei a porta

'ãr po dâr topyõr - eu abri a porta

'ãr po te topyõr - eu ainda estou abrindo a porta

'ãr po-ãm topyõr - eu já estou abrindo a porta

'ãr poẽr dâr topyõr - * (estou abrindo a porta)

'ãr po dârẽr topyõr - eu não abri a porta

'ãr po dâr yũt topyõr wap - eu abri todas as portas

topyõr po xaa - a porta está aberta

topyõr po xaaẽr - a porta não está aberta

topyõr $\operatorname{dim}$ xaa - a porta está fechada

xas - caixa

wap - todas

'ãr po dâr xas - eu abri a caixa

'ãr po rũ' dâr xas - eu abri todas as caixas

'ãr po rũ' dâr xax wap - eu abri todas as caixas 
'ãr po rũ'xas - eu abri todas as caixas

wox - quebrar

rid wap po dâr rũ' xasũuy' - eles todos abriram as caixas

'ãr po dâr rew topyõrũuy' - eu abri muitas portas

‘ãr wox dãr xasũuy' - eu quebrei a caixa

bub ‘ãr wox dâr tuk xasũuy’ - amanhã eu vou quebrar a caixa

‘ãr wox dãr tuk xasũuy' - eu quero quebrar a caixa

‘ãr po dâr tuk topyõrũuy' - eu quero abrir a porta

‘ãr po rẽk topyõrũuy' - eu gosto de abrir a porta

‘ãr po dâr rẽk topyõrũuy' - eu gosto de abrir a porta

‘ãr po dârẽr rẽk topyõrũuy' - * (eu não gosto de abrir a porta)

'ãr po dâr beey topyõrũuy' - eu abri a porta de novo

‘ãr po dâr beeyẽr topyõrũuy' - eu não abri a porta de novo

‘ãr po dâr wutd topyõrũuy - eu tinha aberto a porta/eu ia abrir a porta

'ãr po dârẽr wutd topyõrũuy - eu não ia abrir a porta

top yẽw - a casa é bonita

top yẽw dâr - * (sem sentido)

top yẽw xâd - * (sem sentido)

top yẽw beey - a casa ficou bonita de novo

top yẽw-ãm - a casa já está bonita

top yẽw te - a casa ainda está bonita

top yẽw yũt $-*$ (sem sentido)

top yẽw rũ' - a casa está toda bonita

top yẽw yow - a casa já ficoo bonita

top yẽw tâg - * (sem sentido)

top yẽw wutd - a casa era bonita

bâas - atravessar

nâxpog - rio

'ãr bâas xâd nâxpog - eu atravessei o rio

‘ãr bâas xâd nâxpogũuy’ - * (agramatical com ñuty)

'ãr bâas dâr nâxpog - * (sem sentido)

'ãr bâas yũt nãxpog - eu já atravessei o rio

‘ãr bâs yũtãm nâxpog - eu já atravessei o rio

'ãr bâas te nâxpog - eu ainda estou atravessando o rio

'ãr bâas rũ' nâxpog - eu já atravessei todos os rios

'ãr bâas 'weer nâxpog - eu sempre atravesso o rio

'ãr bâas tâg nâxpog - eu sempre atravesso o rio

'ãr bâas-ãm nâxpog - eu já estou atravessando o rio

'ãr bâas yow nâxpog - eu já atravessei o rio

bub 'ãr bâas yow nâxpog - amanhã já vou atravessar o rio

bub 'ãr bâas-ãm nâxpog - amanhã eu vou atravessar o rio 
bub 'ãr bâas nâxpog - amanhã eu vou atravessar o rio

bub 'ãr bâas te nâxpog - *

bub 'ãr bâas nã te nâxpog - amanhã ainda vou estar atravessando o rio

bub 'ãr bâas 'weer nâxpog - *

bub 'ãr bâas tâg nâxpog - *

bâas - atravessar

nãxpog - rio

'ãr bâas 'uy nâxpog - porque eu atravessei o rio

'ãr weed 'uy dep - porque eu comi carne

'ãr 'õt 'uy - porque eu chorei

'ãr 'õtẽr 'uy - porque eu não chorei

bub 'ãr weed nã'-uy dep - porque eu vou comer carne amanhã

dep - gordo, carne

weed - comer

putd - muito

tir dep tir weed putd uy - ele é gordo porque come muito

tir depẽr tir weed puudẽr uy - ele é magro porque come pouco

daad - escrever

paar - saber

rũ' daad paar - quem sabe escrever

'ãr daad paar - eu sei escrever

'ãr daad paar yũtãm - eu já sei escrever

'ãr daad paar te - eu ainda sei escrever

bertâg - árvore

\begin{tabular}{|l|}
\hline 'a bertâg ‘ãr wãy yẽw - a árvore que eu vi é bonita \\
\hline 'a bertâg 'ãr tes dãr pis - a árvore que eu cortei é pequena \\
\hline 'a bertâg 'ãr tes xâd pis - * \\
\hline
\end{tabular}

nõx - cair

tu - chão

bertâg nõx tu - a árvore caiu

bertâg nõx tu dâr $-*$ (a árvore caiu)

bertâg nõx tu xâd - * (a árvore caiu)

kasãm - morrer

yawi - errar

bertâg kasãm dâr - * (a árvore morreu)

bertâg kasãm xâd - a árvore morreu

bertâg kasãm te - a árvore ainda está morrendo

bertâg kasãm yũt - a árvore já morreu 
bertâg kasãm wutd - a árvore quase morreu

bertâg yawi kasãm wutd - a árvore quase morreu

bertâg yawi kasãm rũ' - a árvore toda morreu/todas as árvores morreram

bertâg yawi kasãm yow - a árvore já morreu

\section{ESTER / DEOLINDA}

bertâg kasãm tuk(-ãm) - a árvore está morrendo

dâwxut kasãm tuk-ãm - o homem já está querendo morrer/está quase morrendo

bertâg kasãmẽr - a árvore não morreu

bertâg kasãm rũ'ẽr - nem todas as árvores morreram

bertâg wap kasãm - todas as árvores morreram

bertâg kasãm-uy - a árvore morreu e não sobrou nada

dâwxut kasãm'uy - porque os homens morreram

dâwxut kasãm rũ'uy - porque todos os homens morreram

dâwxut kasãm rũ'ẽr-uy - porque nem todos os homens morreram

dâwxut kasãm yed - o homem já morreu

dâwxut kasãm rũ' yed - os homens morreram todos

dâwxut kasãm xâdãm - o homem está morrendo

dâwxut kasãm 'weer - o homem sempre morre/os homens sempre morrem

dâwxut weed 'weer dep - o homem sempre come carne

dâwxut cem weed 'weer dep - * (o homem ontem sempre comeu carne - agr. com 'weer)

dâwxut âg tâg nâx = o homem sempre bebe água

dâwxut âg 'weer nâx = o homem sempre bebe água

\section{Construção causativa com dôo'}

dâwãy dôo' kâs dâwtee(ũuy') yamũuy' - a mulher fez a criança morder o cachorro dâwãy dôo' kâs yâm(ũuy) dâwteeũuy' - a mulher fez o cachorro morder a criança dâwãy dôo' âg dâwteeũuy' nâx - a mulher já fez a criança beber água dâwãy dôo' âg yũt dâwteeũuy nâx - a mulher já fez a criança beber água dâwãy dôo' âg rũ' dâwteeũuy nâx - a mulher fez todas as crianças beberem água dâwãy dôo' âg rũ' dãwteeũuy nâx - a mulher fez a criança beber toda a água dâwxut dôo' yũt dâwteeũuy' 'yãmxũuy' - o homem o filho matar a onça dâwxut dôo' yũt rũ' dâwteeũuy' 'yãmxuñuy' - o homem mandou o filho matar todas as onças

dâwãy dôo' tes dâwxutũuy' bertâgũuy' - a mulher fez o homem cortar árvores dâwãy dôo' tes rũ' dâwxutũuy' bertâgũuy - a mulher mandou o homem cortar todas as árvores

Verbo ditransitivo nõ (dar)

xaspay - caixa

dâwxut nõ dâwãyũuy' xaspay - o homem deu uma caixa para a mulher dâwxut nõ rũ' dãwãyũuy' xaspay - o homem deu todas as caixas para a mulher 
dâwxut nõ dâway wapũuy xaspay - o homem deu caixas para todas as mulheres

dâwxut nõ xaspay dâwãy rid - o homem deu uma caixa para a mulher

dâwxut nõ rũ' yed dãwãy rid - o homem deu todas as caixas para a mulher

rãm - ir

taw - cidade

wap - todas

rid - para

'ãr rãmê' taw wap rid - eu fui para todas as cidades

yãm - cachorro

wây - ver

'ãr wây 'yãmũuy' cem - eu vi o cachorro ontem

'ãr weed tuk dũ' weed dep - eu também quero comer carne

'ãr wây tuk dũ' 'ãmũuy' - eu também quero ver você

\section{QUARTA-FEIRA}

falante: VALTEIRZINHO

wutd - chegar

rãm - ir

tir wutd 'ãr rãm yow nã - quando ele chegar eu já terei ido

tir wutd 'ãr rãm yũt nã - quando ele chegar eu já terei ido

tir wutd 'ãr rãm rũ' nã - *

tir wutud 'ãr rãmtee nã -*

tir wutd 'ãr rãmãm - *

'ãr rãm-ãm - eu já estou indo

bub 'ãr rãm-ãm - amanhã eu já estou indo

bub 'ãr rãm yow - amanhã eu estou indo

bub ‘ãr weed yow - * (sem sentido)

cem - ontem

nãk - açaí

cem 'ãr weed yow nãk - * (sem sentido 'ontem eu comi açaí)

cem 'ãr weed-ãm nãk - * (sem sentido)

'ãr weed rũ' nãk - eu comi todo o açaí

'ãr weed wât wap nãk - eu comi açaí todo dia

wât wap 'ãr weed rũ' nãk - * (agram. com rũ') 


\begin{tabular}{|l|}
\hline 'ãr weed dâr nãk - * \\
\hline 'ãr weed xâd nãk - * \\
\hline 'ãr weed tâg nãk - eu já experimentei açaí \\
\hline
\end{tabular}

yok - nadar

'ãr yok tâg mug - eu já nadei aqui

'ãr yok yũt mug - eu já nadei aqui

'ãr yok yow mug - *

'ãr yok te mug - eu ainda nado/estou nadando aqui

'ãr yok wutd mug - eu ia nadar aqui

tir siibẽr wutd munh - ele não ia me beliscar

bax - aparecer

tir bax mug - ele apareceu aqui

tir bax tâg mug - ele já apareceu aqui

tir bax yũt mug - ele já apareceu aqui

tir need wuud bug tir needẽr - ele ia vir daí não veio

tir bâ dâr nâx - ele derramou água

tir bâ xâd nâx - ele passou derramando água

tir câk xâd bigid - ele pulou de repente

tir câk dâr bigid - *

tir câk yũt bigid- ele pulou de repente

tir câk-ãm bigid - *

sõm - gota

xutu - chão

tłu sõm xutu xâd - caiu uma gota no chão

tuu sõm xutu dâr - *

tuu sõm xutu yũt - caiu uma gota no chão

tÆu sõm xutu-ãm - ja pingou uma gota no chão

tuu sõm xutu wutd - ia cair uma gota no chão

tuu sõm xutu yow - já caiu uma gota no chão

tuu sõm xutu tâg $-{ }^{*}$ sem sentido (gota sempre pinga)

tuu sõm xutu 'weer - sempre pinga uma gota no chão

tir ne 'weer tâg 'a - ele sempre faz isso

tir yok 'weer tâg mug - ele sempre nada aqui

tir âg tâg nâx - ele sempre bebe água

tir âg 'weer nâx - ele sempre bebe água

tir âg 'weer tâg nâx - ele sempre bebe água 
tir âg tâg 'weer nâx - *

'ãr weed 'weer cem - eu sempre como à noite

'ãr weed tâg cem - sempre como à noite

'ãr rân 'ãr weed 'weer cem - quando eu for velho sempre vou comer à noite

'ãr rân 'ãr weed tâg cem - *

'ãr weyteen 'ãr weed 'weer cem - quando eu era pequeno eu comia à noite

'ãr weyteen 'ãr weed tâg cem - quando eu era pequeno eu comia à noite

dâwtee uubãm - a criança já está acordando

dâwtee uub yow - a criança já está acordando

dâwtee kogogn - a criança está desmaiando

dâwtee kogogn-ãm - *

dâwtee kogogn rãm - a criança desmaiou

dâwtee kogogn yow - a criança desmaiou

dâwtee kogogn yũt - a criança desmaiou

'ãm yâa dâwtee kogogn rãm nã - quando você chegar a criança já vai ter desmaiado

'ãm yâa dâwtee weed yũt nã nãk - quando você chegar a criança já vai ter comido o açaí

'ãm wutd dâwtee peg-ãm nã - quando você chegar a criança já vai estar grande ‘ãm wuud dâwtee kasãm 'ãm nã - quando você chegar a criança já vai ter morrido

'ãr nĩ-ãm mug - eu já estou aqui

‘ãr reg-ãm - eu já estou cansado

bub ‘ãr reg-ãm nã - amanhã já vou estar cansado

teen cemid te - agora ainda é cedo

teen du-ãm - agora já é tarde

tir paarãm mẽenh xaat - ele já sabe meu nome

tir paar yũtãm mẽenh xaat - ele já sabia meu nome

bub tir paar mẽenh xaat - amanhã ele vai saber meu nome

bub tir paar nã mẽenh xaat - amanhã ele já vai saber meu nome

tir paarẽr mã mẽenh xaat - ele não sabe mais meu nome

mẽenh maam rãmẽr mã taw rid - meu amigo não vai mais pra cidade

tir weed ka' yeg ked - ele está comendo na rede

daad paaror mẽenh xaat - aprenda a escrever meu nome!

'ãr lêr paar eskol but - eu aprendi a ler na escola

'ãr lo liib taw rid/taw wâ - eu comprei um livro na cidade 
'ãr deel wĩnh - eu posso trabalhar

'ãr deelẽr wĩnh - eu não posso trabalhar

'ãr deelẽr wĩnh wutud - eu não podia trabalhar

bub 'ãr deelẽr wĩnh - amanhã não vou poder trabalhar

bub 'ãr wĩnh (nã) - amanhã eu tenho que trabalhar

dâw yum nã - para as pessoas viverem

dãw wĩnh nã - para as pessoas trabalharem

pilsij - precisar de (+nome)

bub 'ãr pilsij wĩnh - amanhã eu preciso trabalhar

bub 'ãr pilsij wĩnh te - amanhã eu ainda preciso trabalhar

bub 'ãr pilsij wĩnh yow - *

bub ‘ãr pilsij wĩnh-ãm - *

bub ‘ãr pilsij wĩnh rãm - amanhã estou indo trabalhar

bub 'ãr deel wĩnh - amanhã eu posso trabalhar

bub 'ãr deel wĩnh te - amanhã eu ainda vou poder trabalhar

bub 'ãr deel wĩnh yow - *

bub 'ãr deel wĩnh-ãm - *

bub 'ãr deel wĩnh rãm - vou poder ir trabalhar

tir nĩ pay tir top - ele deve estar em casa

tir wĩnh pay teen - ele já deve estar trabalhando

tir need pay - ele deve estar vindo

tir need pay te - *

tir need te pay - ele ainda deve estar vindo

rid need rũ' pay - eles todos devem vir

'ãr wĩnh nã taw wâ - eu trabalho nesta cidade

tir need yow pay - ele deve ter vindo/acho que ele veio

tir need yũt pay - ele já deve ter vindo

tir need 'weer pay - ele sempre deve vir

tir need yow tir rãm yow - ele veio mas já foi embora

$\mathrm{yu}-\mathrm{sol}$

yuẽr - sombra

yor yu'ê - estava fazendo sol

'yãm 'ãa yet yuẽr but - o cachorro está deitado na sombra

'ãr wĩnh nũ' wât - eu vou trabalhar outro dia

Báal taw peg pud wutd - Manaus era uma cidade grande 
yũt yed 'yãmũuy' - mate o cachorro!

yũtor 'yãmũuy' - mate o cachorro!

yũtẽrĩr 'yãmũuy' - não mate o cachorro!

kâsor weed dep - morda a carne!

weedor rũ' dep - morda a carne toda!

weed rũor dep - morda a carne toda!

xaaw - ferver

dôo’ xaaw nâx - ferva a água!

buu nâx - despeje a água!

butor nâx - não despeje a agua!

but yũtor nâx - *

butor yũtor te nâx - *

butur wutud nâx - *

but wutdor nâx - *

butot yow nâx - *

rodor - saia!

rod xâdor - saia!

rod dâror - *

weed dâror - come logo!

weed xâdor - come passando!

wam wãnpis - amolar a faca

wamor wãnpis - amole a faca!

wamẽrĩr wãnpis - não amole a faca!

wamõr yũt wãnpis - *

wam rũ' wãnpis - amole todas as facas!

wam rũ' yedor wãnpis - amole todas as facas!

weed rũ' yedor nãak wap - coma todo o açaí!

weed rũ' yedor nãak peg red - coma todos os açaís!

yar need - trazer

paas - pedra

mũunh -1 sg objeto

yar need paas mũunh - traz uma pedra pra mim!

yar needor paas mũunh - não traz uma pedra pra mim!

yar need paas wap mũunh - traz todas as pedras pra mim!

yar need rũ' paas wap mũunh - traz todas as pedras pra mim!

yar need paas peg red mũunh - traz a pedra inteira pra mim! 
yar need rũ' paas peg red mũunh - traz a pedra inteira pra mim!

yar need mũunh mutwap paas - traz 3 pedras pra mim!

yar need rũ' mutwap paas mũunh - traz todas as 3 pedras pra mim!

yar need mutwap paas wap - * (agram. com wap e numeral)

rid nê top - eles fizeram casa

rid nê top peg red - eles fizeram a casa grande inteira

rid nê rũ' top peg red - eles fizeram a casa grande inteira

rid nê rũ' top - eles fizeram todas as casas

rid yok wât wap - eles nadaram todos os dias

rid yok wât rey - eles nadaram o dia todo

rid wap yok wât wap - eles todos nadaram todos os dias

rid yok rũ' wât wap - eles todos nadaram todos os dias

rid yokẽr mã wât wap - eles não nadaram mais todos os dias

'ãr wây maam tukẽr 'ãm did - eu não quero mais falar com você

tir ran wãnpis mũunh - ele me mostrou a faca

‘ãr ran wãnpis tirũuy' - eu mostrei a faca pra ele

'ãr ran wãnpis mũuy - eu mostrei a faca pra você

tir ran wãnpis ‘idũuy' - ele mostrou a faca pra nós

tir ran wãnpis dâwteeũuy - ele mostrou a faca pra criança

wãnpis mẽj wâ wob mũunh - a faca sobre a mesa é minha

wãpis xaas ked nĩ mũunh - a faca dentro da caixa é minha

top 'a taw nĩ mũunh - a casa na cidade é minha

'ãr lo top taw wâ - eu comprei a casa na cidade

'ãr wôob liib mẽj wâ' - eu coloque o livro na mesa

liib ‘ãr mẽj wâ wôob peg pud - o livro que eu coloquei sobre a mesa é muito grande

sãr - pensar

'ãr sãr tir need bub - eu acho que ele vem amanhã

'ãr yarsãr tir need 'mug - eu ensinei ela a vir a aqui

dâwtee núu' winh'ĩi - a criança parece um rato

dâwtee núu' winh'ĩi wutud - a criança parecia um rato

dâwtee núu' pud winh'îi - a criança parece muito um rato

(pud só pode vir antes de winh'îi) 
nẽem câk xâd kasmãy ked/but - o piolho pulou dentro do buraco

nẽem câk dâr kasmãy ked/but - *

tir dârdâar - ele engoliu

tir xupwoc xâd - ele se assustou

tir xupwoc - ele se assustou

tir xupwoc dâr - *

tir xupwoc yũt - ele se assustou

tir xupwoc yũtam - ele se assustou

tir xupwoc yow - *

tir xupwoc te - ele ainda se assusta

tir xupwoc wutd - ele ia se assustar

tir xupwoc rũ' - *

yũtãmẽr $=*$

não existe yũtãm negado, apenas yũt $>$ yũtẽr

wutd também não pode levar -ẽr

rũyẽr

tir weed rũyẽr - ele não está podendo comer (p. ex. pq está doente)

tir paar rũyẽr - *

tir xupwoc rũyẽr - ele não consegue se assustar (falante considera sem sentido)

tir mẽrãm - ele não tem mais/ ele já não tem

tir yokẽr - ele não nada

tir yokẽrãm - ele já não nada

tir wâyẽr rãm - ele já não fala mais

tir nê nãm - ele faz hoje

tir neê yor - ele fez hoje

'ãr rãa' líib mẽj wâ' - eu deixei o livro na mesa

tir rãa’ nâx kop ked - ele pôs água no copo

tir wâay'yar dâwãyũuy' - ele mentiu pra mulher

tir wâay'yar yũt dâwãyũuy' - ele mentiu pra mulher

tir wâay'yar wutd dâwãyũuy' - ele ia mentir pra mulher

tir wâay'yar yow dâwãyũuy' - *

tir wâay'yar rũ' dâwãyũuy' - *

tir wâay’yar tâg dâwãyũuy' - ele sempre mente pra mulher

tir wâay'yar 'weer dâwãyũuy' - ele sempre mente pra mulher

tir wâay’yar xâd dâwãyũuy’ - * 
tir wâay’yar dâr dâwãyũuy' - *

tir weed yow $=*$ (ele comeu $)$

tir weedẽr mã $=$ ele não come mais

dâwtee 'õt - a crianã está chorando

dâwtee 'õtam - a criança está chorando

dâwtee 'õt te - a criança ainda está chorando

dâwtee 'õt bey - a criança está chorando de novo

dâwtee "õt tâg - *

dâwtee 'õt 'weer - criança sempre está chorando

dâwxut wĩnh tâg - o homem sempre está trabalhando

dâwxut wĩnh 'weer - o homem sempre está trabalhando

dâwxut wĩnh xâd - o homem passou trabalhando

dâwxut wĩnh dâr - *

'yãm ok xâd - o cachorro passou correndo

'yãm ok dâr - *

'yãm yũt yed sãan' - o cachorro matou o gato

'yãm yũt dâr sãan' - *

'yãm yũt xâd sãan' - *

tir dej dâr bôol - ele chutou a bola

tir dej xâd bôol - *

'ãr lôok dâr lat - eu furei a lata

'ãr lôok xâd lat - *

'ãr lôok yũt lat - eu furei a lata

lôok xâd lat - a lata furou

'ãr lôok dâr tuu - eu furei o chão

'ãr lôok xâd tuu - *

'ãr lôok-ãm tuu - *

'ãr lôok te tuu - eu ainda estou furando chão

be lôok tuu - o pau furou o chão

be lôok dâr tuu - o pau furou o chão

be lôok yũt tuu - *

be lôok te tuu -* 
'ãr rẽd xop - eu me sequei

‘ãr rẽd xop dâr - *

'ãr xop mũunh xup - eu me sequei

'ãr wây mũunh xup rũywâak rẽd - eu me vi no espelho

tir wây tirũuy' xup rũywâak rẽd - ele se viu no espelho

‘ãm wây mũuy xup rũywâak rẽd - você se viu no espelho

câag lôok dâr tuu - a flecha furou o chão

QUINTA-FEIRA

TATIANE

'ãr weed dep wâat wap - eu comia carne todo dia

'ãr weed yũt dep wâat wap - * (agram. nesse sentido)

dâwtee 'õt wâat wap - a criança estava chorando todo dia

dâwtee 'õt yũt wâat wap - *

dâwtee 'õt yow wâat wap - *

‘ãr weed têen - agora estou comendo

'ãr weed yũt têen - * (agram. nesse sentido)

dâwtee 'õt pud yedê' - a criança tem chorado muito

dâwtee 'õt yũt pud yedê' - *

dâwtee 'õt yow pud yedê' - *

cem pud - ultimamente

'ãr rãm pud yedê' taw rid - eu tenho ido ido muito à cidade ultimamente

mẽ' wâ'ẽn - frequentemente

'ãr rãm mẽ' wâ'ẽn taw rid - eu vou frequentemente à cidade 
'ãr pis tẽn 'ãr âg lêc - quando eu era pequeno eu bebia leite

'ãr pis tẽn 'ãr âg yũt lêc - *

'ãr pis tẽn 'ãr âg yow lêc - *

'ãr pis tẽn 'ãr âg 'weer lêc - quando eu era pequeno eu sempre bebia leite

'ãr pis tẽn 'ãr âg tâg lêc - quando eu era pequeno eu sempre bebia leite

'ãr pis tẽn 'ãr âg 'weer tâg lêc - *

dâwãy siib xaa dâwteeũuy' - a mulher já está beliscando a criança

dâwãy rãm xaa taw rid - a mulher já está vindo pra cidade

'ãr wĩnh xaa 'mũg - eu já estou trabalhando aqui

(na negação aa frase com xaa pode ser passado)

dâwãy paar yũtãm ‘ãm xaat - a mulher já sabe teu nome

dâwãy xub paar tir xaat - a mulher se lembra do nome dele

dâwãy xub paar yũtãm tir xaat - a mulher já se lembrou do nome dele

dâwãy xub paar yow tir xaat - a mulher já se lembrou do nome dele

dâwãy xub paar-ãm tir xaat - *

dâwãy xub paar te tir xaat - a mulher ainda se lembra do nome dele

dâwãy do utb yow dâwteeũuy' - a mulher já acordou a criança

(agramatical no sentido de 'já está acordando...')

tir do uub xaa-ãm dâwteeũuy' - ele já está acordando a criança

tir do umb ta' dâwteeũuy' - ele não acordou a criança

tir do umbẽr ta' dâwteeũuy' - ele nem acordou a criança

tir weed ta' dep - ele não comeu a carne

tir paar ta' 'ãm xaat - ele ne sabe seu nome

tir paarẽr ta' 'ãm xaat - *

tir weey - ele é/está fraco

tir weey wutd - ele era/estava fraco

tir weey ta' - ele é preguiçoso

tir cik - ele é/está sujo

tir cik yũt $-*$

tir cik yow - * (ela já se sujou)

tir cik te - ele ainda está sujo

tir cik rãm - ele se sujou/ ficou sujo

tir cik rãm-ãm - * 
tir cik rũ' - ele se sujou todo

rid cik rũ' - eles se sujaram todos

rid cik 'weer - eles sempre estão sujos

rid cik wutd - *

rid cik tâg - *

tir rẽd cik wutd - ele estava sujo

tir weey yũt - * (ele fraco)

tir pis yũt - ele ficou pequeno

tir peg yũt - ele ficou grande/já cresceu

tir wum yũt - ele ficou forte

tir pis yow - ele ficou pequena

tir peg yow - ele ficou grande

tir pegãm - ele já é/está grande

tir peg tâg - *

tir peg 'weer - ele sempre cresce

tir pis 'weer - ele sempre é pequeno

tir wum 'weer - ele sempre é forte

'ãr rẽk 'weer tirũuy' - eu sempre vou gostar dela

‘ãr rẽk tâg tirũuy' - eu já gostei dela

dâwtee ãa - a criança está dormindo/dormiu

dâwtee ãa you - a criança já dormiu

\section{VALDEMAR}

‘ãr weed têen 'ãr weed lec dâræud - quando eu era pequeno eu tomava só leite

dâwãy daad xaa - a mulher fica sentada escrevendo

dâwãy daad xaaẽr - a mulher não fica sentada escrevendo

dâwãy rãm taw rid - a mulher está indo/vai/foi pra cidade

dâwãy rãm xaa taw rid - a mulher vai sempre pra cidade

dâwtee cik - a criança está suja

dâwtee cik wutud - *

dâwtee cik yow - a criança está ficando suja

dâwtee cik-ãm - a criança está ficando suja

dâwtee rẽd cikãm - a criança já ficou suja 
dâwãy do uub dâwteeũuy' - a mulher está acordando a criança

dâwãy do uub yow dâwteeũuy' - a mulher já acordou a criança

dâwtee pis - a criança é pequena

dâwtee pis wutd - a criança é pequena

tir weedẽr yũt - ele não comeu

tir weed yũtẽr - ele ainda não acabou de comer

tir âg yũtẽr nâx - ele não conseguiu tomar água

'ãr wây rũ' dâwũuy - eu vi todo mundo

'ãr wây rũ' daw wap duty - eu sempre vejo todo mundo

'ãr wây rũywâak rẽd - eu vi no espelho

'ãr wây rũ tawutd daw wap duty - eu vi quase tudo

tir 'ây mũunh - eles me chamaram

rid wây rũ' - eles viram tudo

bub rid weed yũt - amanhã eles já terão comido

bub rid weed te - amanhã eles vão estar comendo

bub rid weed rũ' te - amanhã eles vão estar comendo tudo

bub rid weed rũ' yũtãm - amanhã eles vão comer tudo

bub rid weed rũ' yow - amanhã eles vão comer tudo

bub rid weed yũt rũ' - amanhã eles vão comer tudo

bub rid âg yũt rũ' nâx - amanhã eles vão tomar toda a água

bub rid âg te rũ' nâx - amanhã eles vão tomar água de novo

bub rid âg yow rũ' nâx - *

cem rid âgê' nâx(ũuy') - ontem eles estavam bebendo água

cem rid âg nâx - ontem eles beberam água

rod pud 'ãr nẽed taw rid - às vezes eu venho à cidade

'ãr nẽed taw wâ' - eu venho da cidade

'ãr nẽed Baal rid/wã - eu venho de Manaus

weed yẽw taw wâ' - a comida é boa na cidade

'ãr lo weed - eu vendi/comprei comida

'ãr loam weed - eu vendi/comprei comida 
wéed mãy peg - a comida é cara

wéed mãy peg pud yed - a comida é muito cara

wéed mãypeg wutd - a comida era cara

wéed rũ-ãm - a comida acabou

wéed kas - a comida é ruim

wéed kas wutd - a comida estava ruim

\section{Índice de Tabelas e Figuras}

Figura 1 - tela do léxico Dâw no software FieldWork Language Explorer, do Summer

Institute of Linguistics, base lexical usada na presente pesquisa - pág. 12

Figura 2 -imperfectividade e suas sub-categorias (Comrie, 1976) - pág. 23

Figura 3 - perfectividade vs. imperfectividade (gráfico) - pág. 24

Figura 4 - Distribuição geográfica das línguas Nadahup (mapa) - pág. 33

Figura 5 - Subdivisão da família Nadahup (Epps, 2005) - pág. 34

Tabela 1 - Abreviaturas usadas nas glosas - pág. 15

Tabela 2 - Consoantes Dâw e sua ortografia - pág. 16

Tabela 3 - Vogais Dâw e sua ortografia - pág. 17

Tabela 4 - Relações temporais de Reichenbach - pág. 20

Tabela 5 - Principais aspectos em Comrie (1976) - pág. 23

Tabela 6 - Classes aspectuais de Vendler + Comrie - pág. 31

Tabela 7 - Classificação dos verbos Dâw segundo Martins - pág. 38

Tabela 8 - Afixos verbais em Dâw - pág. 39

Tabela 9 - Marcadores de aspecto e cognatos em Dâw (Martins) - pág. 40

Tabela 10 - Dados atualizados sobre os 15 morfemas funcionais analisados - pág. 42

Tabela 11 - Marcadores de aspecto em Tariana - pág. 45

Tabela 12 - Marcadores de aspecto e operadores verbais em Tukano - pág. 45

Tabela 13 - Marcadores de aspecto em Hup - pág. 46

Tabela 14 - Resumo de características de xâd e dâr - pág. 99

Tabela 15 - Lista atualizada de morfemas de aspecto - pág. 150

Tabela 16 - lista atualizada de morfemas de modo - pág. 151

Tabela 17 - lista atualizada de morfemas de tempo - pág. 151

Tabela 18 - morfema de evidencialidade - pág. 152

Tabela 19 - operadores verbais em Chinês Mandarim - pág. 152

Tabela 20 - operadores verbais em Cantonês - pág. 153

Tabela 21 - operadores verbais em Tailandês - pág. 153

Tabela 22 - operadores verbais em Birmanês - pág. 154

Tabela 23 - operadores verbais em Vietnamita - pág. 155 